Portland State University

PDXScholar

\title{
The Oregon Volunteers in the Spanish-American War and Philippine Insurrection : the annotated and edited diary of Chriss A. Bell, May 2, 1898 to June 24,1899
}

James Stanley Rost

Portland State University

Follow this and additional works at: https://pdxscholar.library.pdx.edu/open_access_etds

Part of the History Commons

Let us know how access to this document benefits you.

\section{Recommended Citation}

Rost, James Stanley, "The Oregon Volunteers in the Spanish-American War and Philippine Insurrection : the annotated and edited diary of Chriss A. Bell, May 2, 1898 to June 24, 1899" (1991). Dissertations and Theses. Paper 4117.

https://doi.org/10.15760/etd.6001

This Thesis is brought to you for free and open access. It has been accepted for inclusion in Dissertations and Theses by an authorized administrator of PDXScholar. Please contact us if we can make this document more accessible: pdxscholar@pdx.edu. 
AN ABSTRACT OF THE THESIS OF James Stanley Rost for the Master of Arts in History presented November 19, 1991.

Title: The Oregon Volunteers in the Spanish - American War and Philippine Insurrection : The Annotated and Edited Diary of Chriss A. Bell May 2, 1898 to June $24,1899$.

APPROVED BY THE MEMBERS OF THE THESIS COMMITTEE :

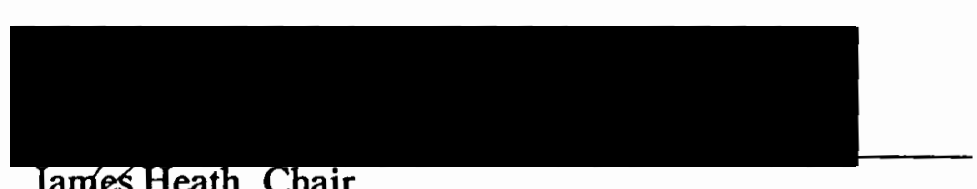

James Heath, Chair
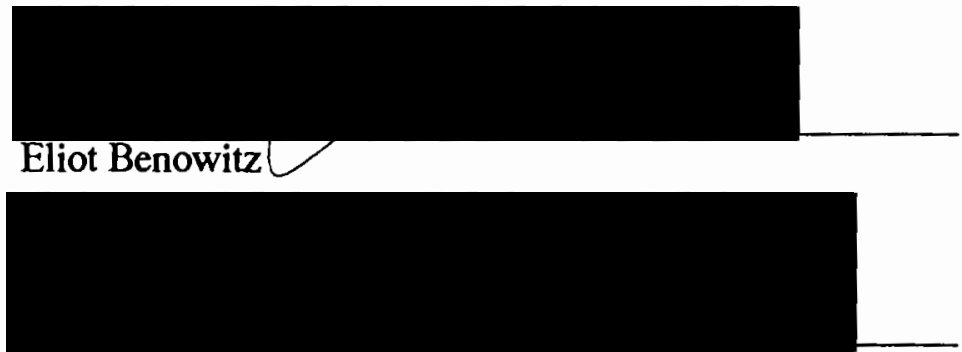

Franklin West

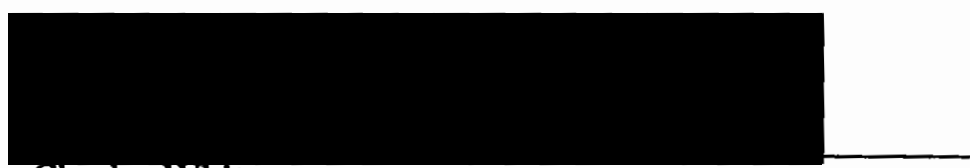

Charles White

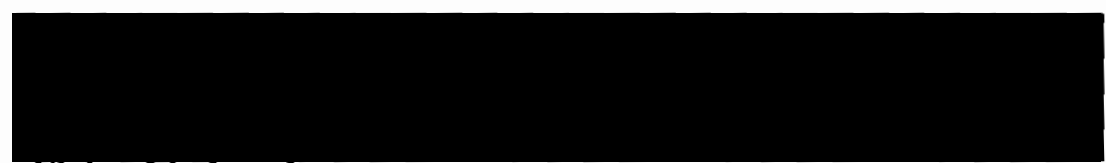

Elaine Limbaugh

This thesis is an annotated and edited typescript of a primary source, the handwritten diary of Chriss A. Bell, of the Second Oregon Volunteer Infantry state militia. The diary concerns the events of Oregon's National Guard state militia in the Spanish - 
American war in the Philippines, and the Philippine Insurrection that followed. The period of time concerned is from the beginning of May, 1898 to the end of June, 1899.

Historical works covering a state militia's involvement in the Spanish - American and Philippine - American war usually have provided complete rosters of names, ranks, residences of soldiers and comments. Typically, comments concern guns, medical conditions, hospital corps, muster rolls and death rolls. Some works on particular states include biographical sketches and brief descriptions of ship and camp life and eyewitness reports of skirmishes, engagements, and battles. There are a few articles but no published works that deal with enlisted life in stateside camps, and reactions of white volunteers to the military experience in the Philippines during the war and insurrection.

The work presented here attempts to fill in one of those important gaps of history, since it focuses on what the experiences and daily life was like for a volunteer to serve in the state militia during the Spanish - American war in the Philippines.

This thesis is based solely upon an original source. The handwritten diary of Chriss A. Bell is now in the possession of then Oregon Historical Society. The diary was supplemented by annotations that involved clarifying what was being stated by Bell as well as providing more depth to the individual entries with statements concerning involvement elsewhere in the Philippines and in the world, specifically Cuba.

The first chapter deals with a summary of the diary and an explanation of the editing that was involved in reorganizing passages into paragraphs and clarifying the meanings of words that Bell uses, as well as how punctuation and grammar were corrected.

The second chapter covers background before Bell was mustered into service. Subjects covered are the Cuban revolt from 1895 to 1897 , the sending and destruction of the battleship Maine, the debates in Congress of the Hull Bill regarding the forming of state militia's, and the sending of volunteer units of states.

In succeeding chapters, the diary is broken up chronologically arranged to periods of activity that Bell experienced. The first period had to do with Bell being mustered into 
service and ended with with his ship arriving at Hawaii. The fourth chapter spanned the time of Bell leaving Hawaii, the capture of Guam, and ends when he entered Manila harbor. The fifth chapter recounted Bell's service in Manila until the fall of Manila. The sixth chapter covered the five month period of inactivity from August, 1898 to January, 1899. The seventh chapter focused on the start of the Filipino insurrection and finished with his term of service in the Philippines 6 months later. An epilogue chapter examined what occurred after Bell and the other Oregon troops left the Philippines until the official end of the Philippine - American war on July 4, 1902.

Oregon Volunteers were actively involved in part of the four year conflict that spanned the war against Spain and the struggle against the Filipino insurrectionists. What Bell had written in his diary typified the feelings of many enlisted men in the $1898-1902$ war and insurrection. The war was fought in an idealistic, simple - hearted, and patriotic aura that was enhanced by the United States popular victory over Spain. Bell's diary represented the way a young man's mind grows and changes once faced with the reality of military life and death and the actual combat.

There are many rumors and talk of going home especially after the fall of the Philippines in August, 1898. No explanations were given by officers and Bell expressed much dissatisfaction with the Army's policies of keeping them there. Games of chess and billiards were resorted to relieve the stress. Their actions that they pursued drew them closer as a company.

Once the fighting started in February, Bell and his company were on duty at the Custom House and remained on duty there in Manila for four months. Much of what he had written showed that he is affected by the war even though they were not seeing any action. He went on a expedition at the end of his tour of duty on the the island of Palawan. He sensed the futility of the military operation when they took control of some small towns, and because there were no more reinforcements, they retreated back to Manila and 
were shipped home. The rainy season also started and no more military maneuvers were to be conducted until September, 1899.

The Philippine war experience affected the enlisted men that fought in the Oregon Volunteers. Bell expressed criticisms at the beginning about the conditions that must be undertaken in order to have performed his duty. He had a lot of problems with food on the ship he was on. The living conditions on the ship were very difficult for Bell to endure. He showed a naive optimism about his journey when he discussed the moral character of other servicemen and the influences of women. A negative attitude developed early in his service because of these conditions that were endured. 


\title{
THE OREGON VOLUNTEERS IN THE SPANISH-AMERICAN WAR AND PHILIPPINE INSURRECTION : THE ANNOTATED AND EDITED DIARY \\ OF CHRISS A. BELL
}

MAY 2, 1898 TO JUNE 24, 1899

\author{
by \\ JAMES STANLEY ROST
}

A thesis submitted in partial fulfillment of the requirements for the degree of

MASTER OF ARTS

in

Portland State University

1991 


\section{TO THE OFFICE OF GRADUATE STUDIES:}

The members of the Committee approve the thesis of James Stanley Rost presented November 19, 1991.

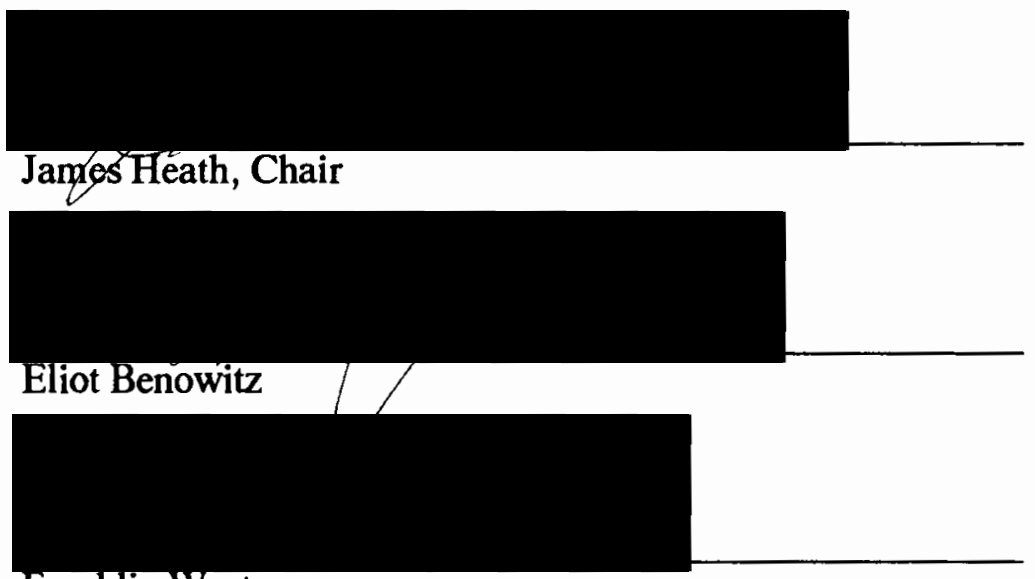

Franklin West

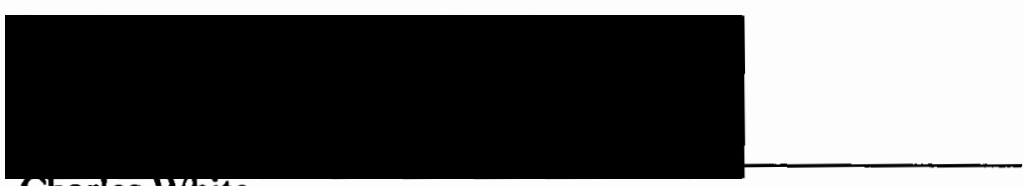

Charles white

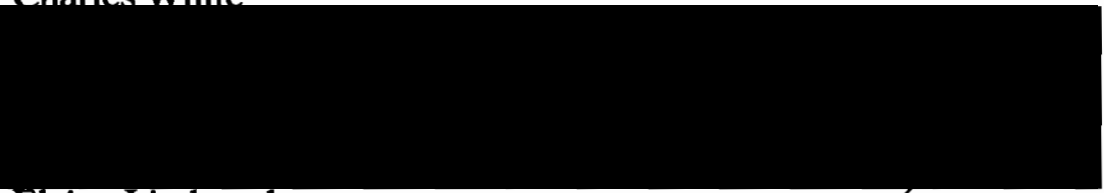

Elaine Limbaugh

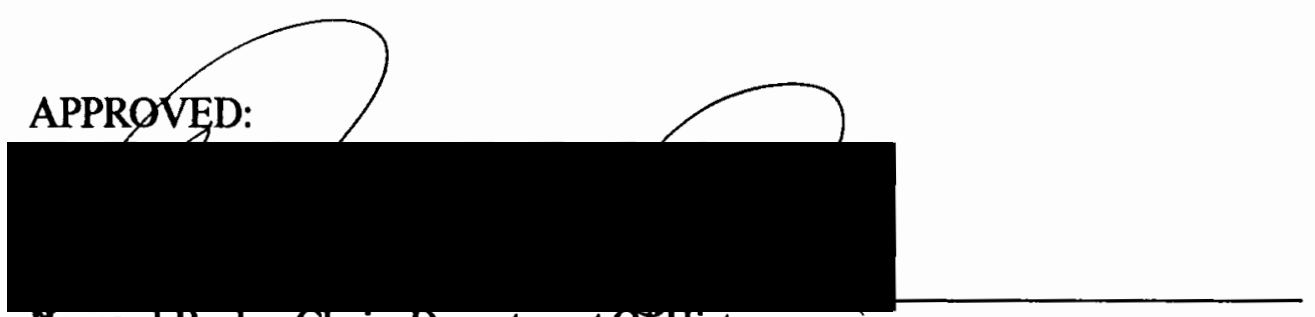

Bernard Burke, Chair, Department Ur History

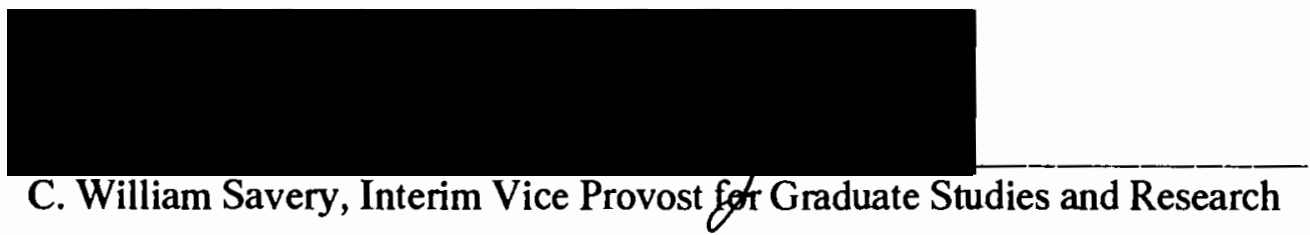




\section{ACKNOWLEDGEMENTS}

I am indebted to many more people than I can mention by name for their help in bringing this work to completion. A few individuals, however, merit special acknowledgement. I would like to thank Professors Eliot Benowitz, Elaine Limbaugh, Franklin West, and Charles White for reading this thesis and for their suggestions and criticisms; I would particularly like to thank Professor James Heath for the help and encouragement and the time spent with me while I got my thesis topic finalized and the help during the writing; Bob Schaefer, for helping me while working at the Oregon Historical Society Library without whose help in dealing with this primary source document this thesis could not have been possible; Ruth Chmura, who helped in making me understand the old handwriting and how the English language changes over time; Jan Delarosa, whose knowledge of the Philippine geography gave me a greater appreciation of the conditions the Volunteer army lived under; Patricia Ann Rost, who helped in the writing and dictation of part of the typescript copy; Charles Rost, for paying the electricity bills; Ann Hafer, whose Mountain Home penned the whole paper; Charles Addams and Robert Ripley and Howard Stern, who kept me awake at night to do my writing after my night shifts finished; and Casey Dugan, who helped me through many of those night shifts. I cannot end without special thanks to my fiance Catherine Margaret Hafer who helped in part of the dictation and dealt with the Spanish - American War almost as long as the U.S. Army did in Cuba, and my family, whose encouragement and substantial help and prayer support in all stages of my work made this paper possible. 
TABLE OF CONTENTS

PAGE

ACKNOWLEDGEMENTS............................................................ii

LIST OF FIGURES...........................................................

CHAPTER

I INTRODUCTION ....................................................

II POLITICAL AND MILITARY ACTIONS FROM 1895 TO1898...........8

III MAY 2, 1898 TO JUNE 3, 1898 : FROM OREGON TO HAWAII.......18

IV JUNE 4, 1898 TO JUNE 30, 1898 : HAWAII TO THE PHILIPPINES..35

V JULY 1, 1898 TO AUGUST 15, 1898 : GETTING SETTLED IN THE PHILIPPINES...............................................52

VI AUGUST 16, 1898 TO JANUARY 4, 1899 : GARRISON DUTY BEFORE THE OUTBREAK OF FIGHTING .64

VII JANUARY 5, 1899 TO JUNE 24, 1899 : THE WAR AGAINST THE INSURRECTIONISTS........................................84

VIII EPILOGUE.......................................................... 121

REFERENCES CITED.......................................................... 135

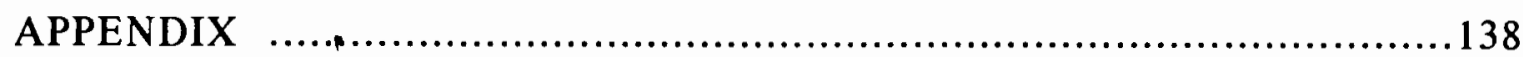




\section{LIST OF FIGURES}

FIGURE

PAGE

1. Page From Original Handwritten Diary................................4

2. Company $\mathrm{H}$ on the Morong Expedition, June, $1899 \ldots \ldots \ldots \ldots \ldots \ldots . . . . .7$

3. Map of Guam .................................................46

4. Blockhouse \# 14 Outside of Manila.....................................63

5. Manila and the Surrounding Areas of the City.........................85

6. The Philippines...............................................86

7. The Four Districts of Luzon.....................................128 


\section{CHAPTER I}

\section{INTRODUCTION}

David F. Trask in his masterful work on the Spanish - American war, The War With Spain In 1898, states in his preface that the short - lived war has not received much scholarly attention compared to other wars in which the United States fought. The Civil War is a case in point. According to Civil War scholar Ken Burns, the numbers of texts written about that war equals approximately one book a day since that war ended. This is proportional to the number of persons involved.

Many historians writing about the Spanish - American conflict have chosen to examine the causes or consequences of the war. Subjects such as foreign relations, press and public opinion, black Americans in the war, the expansion and imperialism (and antiimperialism) of the United States show reasons why the war occurred and changes that took place around the world as a result of the war. There has been a great deal of work done on the actual conduct of the war, but most of that has been limited to the fighting in Cuba.

There has been much less work done on the subject of the Philippine - American War (1898-1902). This conflict, often referred to as an insurrection, was a consequence of Dewey's victory at Manila. The word "war" might be more appropriate than "insurrection", since an insurrection is a revolt against an already established authority, and during the Philippine - American War, Filipino troops were resisting the United States' attempt to impose its authority over the archipelago. 
Early literature on the Philippine - American War was marked by a split between those who supported United States expansion and others who called for an American withdrawal from the Philippines. Recognized historical works include : Leandro $\mathrm{H}$. Fernandez, The Philippine Republic, (New York : Columbia University, 1926); Cameron W. Forbes, The Philippine Islands, (Cambridge, MA : Riverside Press, 1928); Maximo M. Kalaw, The Case For The Filipinos, (New York : Century Company, 1916); James A. Leroy, The Americans In The Philippines, 2 vol., (Boston : Houghton, Mifflin, 1915); Katherine Mayo, The Isle Of Fear : The Truth About The Philippines, (New York : Harcourt, Brace, 1925); James H. Blount, The American Occupation Of The Philippines, 1898 - 1912, (New York : G. P. Putnam, 1912); and Jacob G. Schurman, Philippine Affairs : A Retrospect And Outlook, (New York : Charles Scribner, 1902).

Later works on the war reflected the changing attitude toward empire and many of the post Vietnam works focus on the American response to guerilla activities. Some works that are very credible in this field are : Renayo Constantino, $A$ History Of The Philippines, (New York : Monthly Review Press, 1975); Gavel A. Grunder and William E. Livezey, The Philippines And The United States, (Norman, OK : University Of Oklahoma, 1951); Uldarico S. Bacllagon, Philippine Campaigns, (Manila : Graphic House, 1952); John M. Gates, Schoolbooks And Krags : The United States Army In The Philippines, 1899. 1902,(Westport, CT : Greenwood Press, 1975); Stuart C. Miller, Benevolent Assimilation : The American Conquest Of The Philippines, 1899 - 1903, (New Haven : Yale University, 1983); and William H. Scott, Ilocano Responses To American Aggression, 1900 - 1901, (Quezon City, PI': New Day, 1986).

Volunteers from 41 states of the Union participated in the Spanish - American War, and 19 states had their militia units (National Guard) participate in the Philippine American War. Historical works covering those 19 states usually have provided complete rosters of names, ranks, residences of soldiers, and comments. Typically comments concern guns, medical conditions, hospital corps, muster rolls and death rolls. Some 
works on particular states show photographs, and offer biographical sketches and quick descriptions of ship and camp life and eyewitness reports of skirmishes, engagements, and battles. Unlike the extensive literature dealing with the personal experiences of men during the American Civil War ${ }^{1}$, there are a few articles but no published books that deal with enlisted life in stateside camps and reactions of white volunteers to the military experience in the Philippines during the war and insurrection.

The work that I have undertaken attempts to fill in one of these important gaps of history, since it focuses on what it was like for a volunteer to serve in the state militia during the Spanish -American War in the Philippines. My work deals with the Oregon National Guard's involvement in the Philippine - American War as seen through the eyes of a soldier who served in the Second Oregon Volunteer Infantry state militia.

This work is an edited and annotated typescript of a primary source, a handwritten diary by Chriss A. Bell, now in the possession of the Oregon Historical Society. Unfortunately, relatively little is known about the life of this corporal. In the muster roll of Company H provided by Brigadier - General C. U. Gantenbein in his book The Official Records Of The Oregon Volunteers In The Spanish War And Philippine Insurrection, (Salem, OR : W. H. Leeds, 1902), Bell is described as 24 years old, 5 feet 9 inches, fair complexion, blue eyes, and light brown hair. He was born in Oregon. His occupation was a lawyer. He is listed as being mustered into service on May 13, 1898 in Portland. For his total service he deposited $\$ 65.00$ from his pay.

In my attempt to answer the question of what were the life and experiences encountered for ah enlisted volunteer state militia man serving in the Philippines during the Spanish - American war and Philippine insurrection, this work is organized into chronological periods. The second chapter deals with background before Bell was

${ }^{1}$ Some Civil War diaries that examplify this type of writing includes : Army Life Of An Illinois Soldier : Letter and Diaries of the late Charles $H$. Wills, compiled and published by his sister. Washington, 1906. Downing's War Diary, Sgt. Alexander Downing, edited by Olynthus B. Clark. Des Moines, 1916. Drum Taps In Dixie : Memories Of A Drummer Boy, 1861-1865, Delevan S. Miller, Watertown, New York, 1905. 


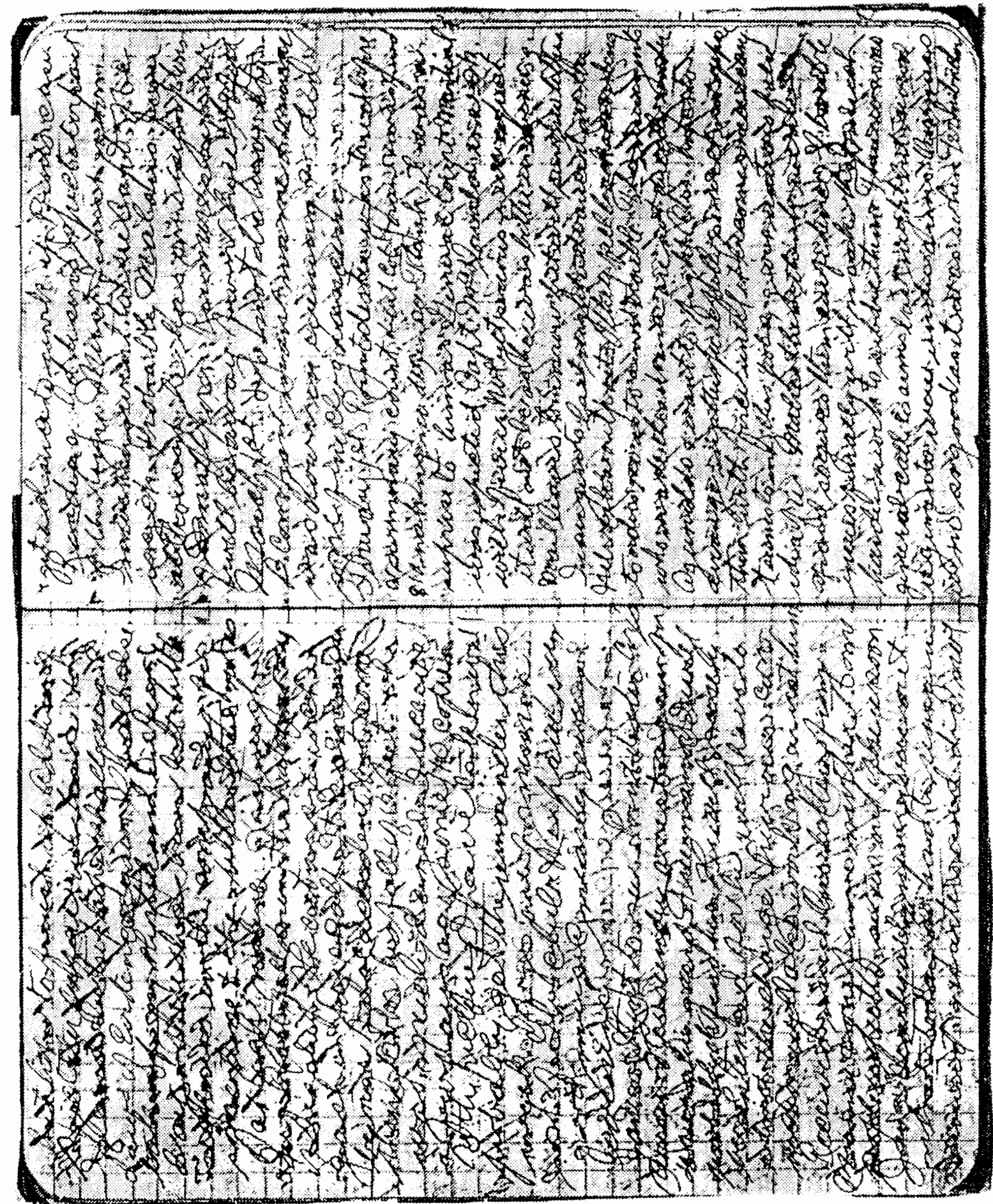

Figure 1. Page From Original Handwritten Diary. This was used to make this lypescript copy. This shows entries from lanuary 30 to Febuary $1,1899$. 
mustered into service. Subjects covered are the Cuban revolt from 1895 to 1897 , the sending and destruction of the battleship Maine, the debates in Congress of the Hull Bill regarding the forming of state militia's, and the sending of volunteer units of states. The third through the seventh chapters are broken up chronologically arranged to periods of activity that Bell experienced. The first period, covered in the third chapter, has to do with Bell being mustered into service and ends with his ship arriving at Hawaii. The fourth chapter spans the time of Bell leaving Hawaii, the capture of Guam, and ends when he entered Manila harbor. The fifth chapter recounts Bell's service in Manila until the fall of Manila. The sixth chapter covers the five month period of inactivity from August to January. The seventh chapter focuses on the start of the Filipino insurrection and finishes with the end of his term of service in the Philippines 6 months later. An epilogue chapter examines what occurred after Bell and the other Oregon troops left the Philippines until the official end of the Philippine - American war.

Readers should be aware that when Bell mentions another fellow soldier by last or first name, a footnote reference is made only on the first writing of the person's name. Each time a reference is given, if the man's name is in initials or not given in full in the text,.the man's full name is provided. Also given is the company in which he served, his age, his occupation at the time of enlistment, his rank at the time of enlistment and any signficant fact that stands out about the individual, including reason for a discharge or cause given for his death, or an award of merit given to the individual.

The editing involved reorganizing passages into paragraphs and clarifying the meanings of words that Bell uses. All words in Bell's diary are spelled exactly as he wrote it, except for certain cases that I will describe. Bell wrote each entry as one paragraph. For the sake of clarity, without omitting words, or placement of words, paragraphs were formed from long passages. An example is May 30, 1898. On board ship, Bell wrote about the food, the sleeping conditions, the sea, the ships, and officers. His words about 
each of those subjects were placed in separate paragraphs. The diary does not look as "cluttered and reckless" as it was originally written.

Where there are obvious misspellings such as in spelling Philippines as Phillippines "sic" is used. All words in brackets are editorial additives. These brackets are used to clarify, or correct names, such as Bell referring to Col. Fran Yoran as Col. Fran, or McKinnon as McK; to correct dates, such as February 1 written as March 1; to clarify vague words such as Bell's girlfriend Lottie sometimes being written as L, or ottie.

In Bell's diary, only the beginning of a month and the entries of the days in that month with just a number were given. Each entry in the edited version has been written out with the month, date, and year. Sometimes in his writing Bell capitalized certain words that for him showed importance such as Mother, these were not corrected. Quotations of conversations that he heard, Bell often punctuated only the beginning of the speaking and not the end. Quotation marks have been used at both ends. In writing sentences in his entries, Bell would occasionally go on to the next sentence starting with a capital letter and not put a period between the ending and beginning of the sentences. Again for clarity and readability, periods were added where they should have gone. Finally, readers should be aware that all diary entries did not end with a period, an error corrected by the editor. 


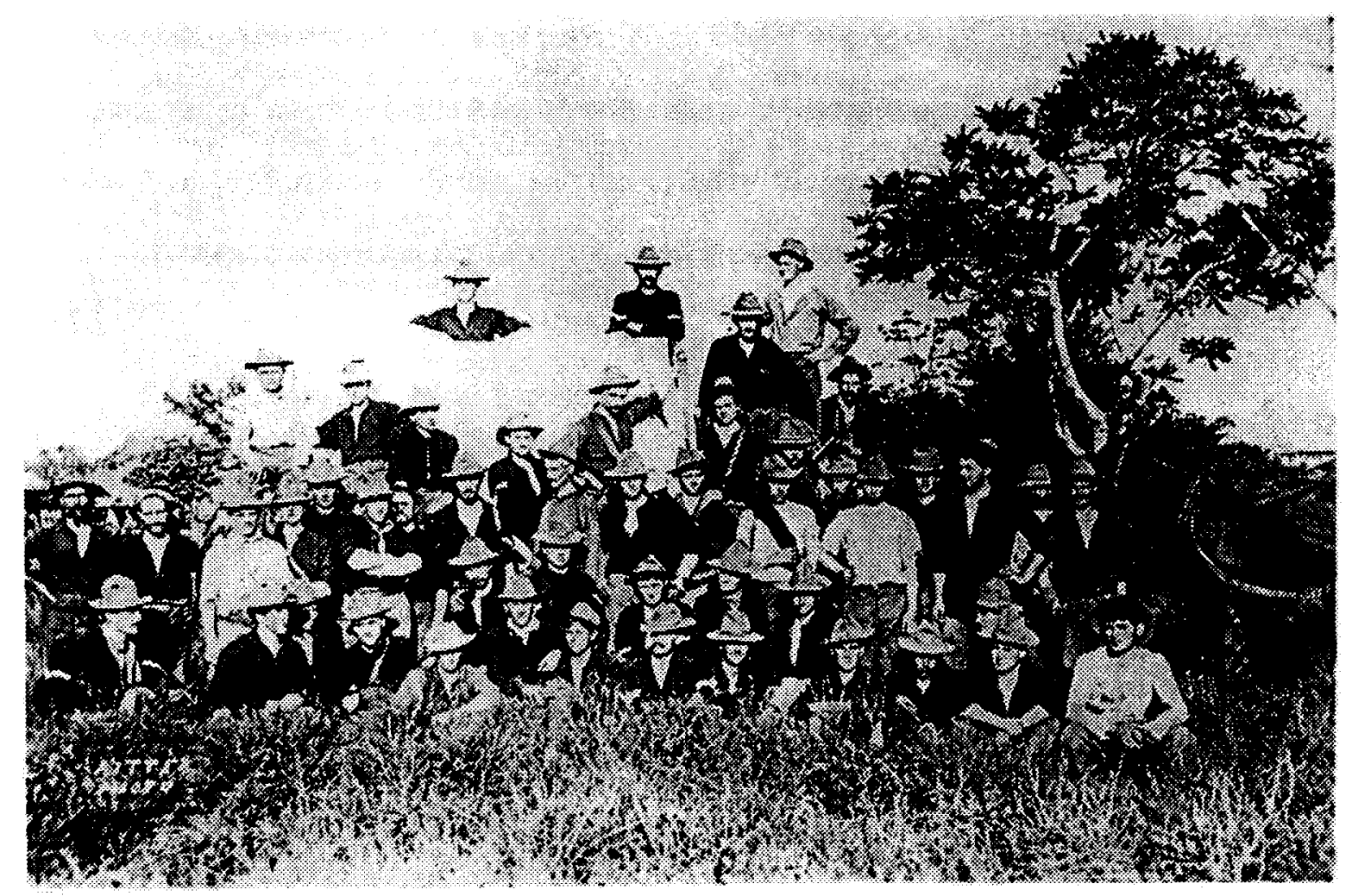

Figure 2. Company H on the Morong Expedition, June, 1899. Oregon Historical Society Negative Number - $5336 \$ 993$ - B. 


\section{CHAPTER II}

\section{POLITICAL AND MILITARY ACTIONS FROM 1895 TO 1898}

In the three years before Oregon's National Guard militia was mustered into service, an exciting sequence of political and military actions occurred which culminated in the Spanish - American War. This paper gives a brief overview of the events that occurred in Spain, Cuba, and the United States will follow along with a summary of Congressional actions in regard to state militias, and the 112 day "Splendid Little War." This overview sets the frame of reference for Chriss A. Bell's entrance into military service, on May 4, 1898.

On February 25, 1895 a group of Cuban dissidents started an armed uprising against Spanish authority. ${ }^{1}$ Spain soon proved it was not able to put down the rebellion. Maximo Gomez was the Commander - in Chief of the revolutionary army. He allied himself with the popular leader, Antonio Maceo. Both felt that Spain could not be defeated in the field so war against Cuba's economy was conducted by pillaging and burning the island's material resources. The two commanders used the military tactic similar to that of the south in the Civil War : don't win the battles but wear out the opposition and when the opposition is exhausted, the struggle would be over. The insurgents did not have to win;

1 Several books give greater detail on Cuba's background before and right up to U.S. involvement militarily. These books are : Jules R. Benjamin, The United States and Cuba : Hegemony and Dependent Development, 1880-1934 (Pittsburgh : University of Pittsburgh Press, 1977). Charles E. Chapman, $\underline{A}$ History of the Cuban Republic, A Study In American Politics (New York : MacMillan, 1927). Philip S. Foner, The Spanish-Cuban-American War and the Birth Of American Imperialism 1895 - 1902 (New York: Monthly Review Press, 1972). 
they just had not lose. By the end of the year, Maceo and Gomez effectively controlled the countryside and the Spaniards the urban centers.

In 1896, General Valeriano Weyler y Nicolau took command of the Spanish military, and issued a decree of reconcentration. This decree ordered the inhabitants of Sancti Spiritus, Puerto Principe', and Santiago de Cuba to place themselves near military headquarters. The citizens were not allowed to travel without permission. Any citizen that provided aid and comfort to the insurgents became subject to military law. ${ }^{2}$ Due to this decree the insurgents were soon deprived of of subsistence and ammunition and also denied of the support of the countryside. The reconcentration policy caused a outcry in the United States because it was directed at innocent civilians. In 1898 estimates suggested that over four hundred thousand Cubans - one fourth of the population - had perished because of Weyler's policy. The true total was only one hundred thousand, but the inflated estimate helped convince U.S. citizens to urge intervention in Cuba's interests. ${ }^{3}$

On June 12,1895 , Shortly after the Cuban insurrection began President Grover Cleveland issued a proclamation of neutrality that recognized Cuban insurgency but fell short of granting Cubans the right of belligerency under international law. 4 On April 6, 1896, Congress passed a joint House and Senate resolution recognizing the Cuban revolution and extending the good offices of the United States. ${ }^{5}$ Two days earlier Secretary of State Richard Olney had sent a note to Spain stating that the United States would support the Spanish government if Madrid agreed to mediation. On the 4th of June Spain rejected all proposed reforms.

${ }^{2}$ David F. Trask, The War With Spain In 1898 (New York : Macmillan 1981), p. 5-7.

${ }^{3}$ G. J. A. O'Toole, The Spanish American War an American Epic - 1898 (New York :W.W. Norton, 1984), p. 57.

${ }^{4}$ Ibid., p. 65.

${ }^{5}$ Congressional Record, 54th Congress, 1st Session, vol.XXVIII, p. 3614-3615, 3627-3628. 
In the 1896 election neither William Jennings Bryan, the Democratic candidate, nor William McKinley, the Republican nominee, commented on the Cuban insurrection. Before he took office McKinley made a statement regarding his pacific inclinations. He said, "We want no wars of conquest,...we must avoid the temptation of territorial aggression. War should never be entered upon until every agency for peace has failed ; peace is preferable to war in almost every contingency."6 His allies within the Republican party were also strongly opposed to war and preferred the new administration concentrate on stimulating the economic recovery at home from the long recession which began in 1893.7

In December 1896, Maceo was killed. On April 29, 1897, Spain's Prime Minister Antonio Canovas del Castillo said reforms would be introduced in the pacified areas of Cuba. However, his reforms were very slow in taking effect. What was at stake was the legitimacy of Spain as a country. Spain had looked upon their grand domain in the New World from the 16th century on as literally a gift from God. To surrender Cuba was to deny Spain part of its national heritage. ${ }^{8}$ After Canovas's assassination on August 8 , 1897, the American envoy, General Stewart Lyndon Woodford, went to the Queen Regent on September 13, 1897. Woodford stated that Spain should provide assurances that "would satisfy the United States that early and certain peace can be promptly secured, and that otherwise the United States must consider itself free to take steps as its Government should deem necessary to procure this result with due regard to its own interests." 9

6 Paolo Coletta, ed. Threshold To American Internationalism; Essays on the Foreign Policies of President William McKinley (New York : Exposition Press, 1970 ), p. 12-13.

${ }^{7}$ David F. Trask, The War With Spain In 1898 (New York : MacMillan, 1981), p. 13.

${ }^{8}$ Ernest R. May, Imperial Democracy: The Emergence Of America as a Great Power (New York: Harcourt, Brace, and World, 1961), p. 132.

${ }^{9}$ Paolo Coletta, ed. Threshold to American Internationalism : Essays on the Foreign Policies of President William McKinley (New York : Exposition Press, 1970) p. 42. 
In 1897 McKinley pressed Spain to adopt autonomy for Cuba. Spain followed that course, but tensions were still raised because Cuban insurgents, sensing victory within their grasp, would not settle for any arrangement short of independence. Even with the grant of autonomy by Spain, Cuba's situation showed no signs of real improvement.by the end of the year. In McKinley's first annual message to Congress on December 6, 1897, there were many statements on the evils of reconcentration and calls for ending the inhumane practices in Cuba. 10 Consul General Fitzhugh Lee reported from Havana that fifty - two thousand out of one hundred thousand reconcentrados had perished in the Havana province and that the available funds for relief amounted to only about seventeen cents per person and could not be expected to help materially improve the situation. ${ }^{11}$

On January 12, 1898, a riot broke out in Havana. The mob was made up of Spanish civilians demonstrating against Havana newspapers that were in favor of autonomy. ${ }^{12}$ On the morning of January 24 President McKinley decided to send an American Battleship, the U.S.S. Maine, to Havana harbor. The ship was to be sent on a friendly visit to Cuba, for Spain and the United States were still at peace, in the hope that the ship would have a calming effect. In addition, the Maine would be available to protect American lives. The Maine was the logical choice because since October, 1897, the ship had been set aside for an emergency in Cuba. The Maine had been stationed at Key West, Florida, since mid - December. Given the American belief that matters in Cuba were

${ }^{10}$ Congressional Record 55th Congress, 2nd session, vol. XXXI, p. 2-9.

11 David F. Trask, The War With Spain In 1898 (New York : MacMillan, 1981) p. 22-23. Also see two articles written early the following year on conditions in Cuba. They are : H. Martin's "Cuba : Concentration, Starvation, and American Relief", Harpers Weekly, (April 9,1898), p. 346-347 and "Cuba : Distribution of American Relief in Mantanzas and Havana”, Harpers Weekly, (April 2, 1898), p. 316-318.

12 G. J. A. O' Toole, The Spanish War an American Epic - 1898 (New York : W.W. Norton, 1984), p. 111-112. 
coming to a crisis, historian French Chadwick wrote that sending the ship was a wise decision and it drew the support of Republican and Democratic leaders in congress alike. ${ }^{13}$

On Tuesday, February 15, 1898, at 9:40 p.m. the U.S.S. Maine exploded in the harbor at Havana, Cuba. Out of the 354 officers and men, 266 lost their lives. An American Court of Inquiry was convened to investigate the cause of the explosion of the ship. The Spanish also did an investigation because the explosion occurred in their harbor. The Americans interviewed sailors, divers, officers, and on March 17, concluded that the Maine had been destroyed by a submerged mine, but the inquiry was unable to fix responsibility for the placing of the mine. However, in 1976, Admiral Hyman G. Rickover published a book How The Battleship Maine Was Destroyed (Washington D. C. : Naval Historical Division, 1976) and used a great deal of experience that had been gained in analyzing ships damaged by external and internal explosions. Ib S. Hansen of Naval Ship Research and Development Center and Robert S. Price of the Naval Service Weapons Center examined carefully all known evidence and did a report titled "The U.S.S. Maine: An Examination of the Technical Evidence Bearing on its Destruction." A brief summary is in order because the importance of the Maine 's loss caused the mood of the country to pass initial shock and suspicion and caused McKinley to give into the popular demand for war.

At the moment of the explosion there was no wind and the water was smooth. Because the ship was motionless, a mine would have had to be detonated by electricity rather than contact with the hull, but neither wires or a control station was discovered. A mine also produces a column of water and none was observed. There were also no dead fish found, as there usually are after an underwater explosion. ${ }^{14}$

13 French E. Chadwick, The Relations of the United States and Spain. vol.1 (New York : Charles Scribner's Sons, 1909), p. 5-6.

${ }^{14}$ H. G. Rickover, How The Battleship Maine Was Destroyed, (Washington D.C. : Naval Historical Division, 1976), p. 72. 
It was believed by Rickover that a fire occurred in coal bunker A-16. Bituminous coal of the kind that the Maine carried had ignited through spontaneous combustion. A fire like that would be difficult to detect because it would smolder deep below the exposed surface of the coal giving off no smoke or flames or raising the temperature of the room. That bunker had not been inspected for over 12 hours before the explosion, which would have given the coal ample time for a fire to begin heating the adjacent compartments, particularly the adjacent compartment Magazine A-12 M that held the shells for the different size guns on the ship. 15

Only a mine with 100 pounds of explosives in contact with the ship bottom would have had any chance of igniting the magazine where the explosion occurred. It would have been very difficult to place a mine like that. It is unlikely that civilians were able to do that and it is also doubtful that a military personnel could have accomplished it without being detected. One more fact is that an external burst would have mangled the ship bottom a type of damage not found in the wreckage. Rickover's study thus found no evidence that a mine destroyed the Maine. 16

But in March and early April, 1898, the War Department made preliminary arrangements for organizing and equipping an expeditionary force. Commanding General Nelson Appleton Miles saw no need in the prospective war for a vast number of citizen soldiers. ${ }^{17}$ The War Department undertook a campaign for an expansible army. Support was found in Representative John A. T. Hull, an Iowa Republican and Chairman of the House Committee on Military Affairs. Hull considered the National Guard useless for offensive action ahd supported expanding the army. On March 17, The Hull Bill was

15 Ibid., p. 91.

16 Ibid., p. 91, 127.

17 Graham A. Cosmas, An Army for Empire : The United States Army and the Spanish-American War, (Columbia, Mo : University of Missouri Press, 1971), p. 89. Hereafter cited as Graham Cosmas. 
introduced into the House What the Hull Bill stated was that the President in time of war could expand the Regular Army from a peace basis of 27,000 to a war footing of 104,000. The National Guardsmen were urged to enlist as individuals in the expanding regular units The Regulars would be the only ones used in offensive operations and the National Guard were to be limited to coastal defense. ${ }^{18}$

National Guard personnel realized that they would have to join the Regular Army if they wanted to see action. Militia officers would not be able to serve unless they gave up their commissions. The state militia men, along with the support of Southern Democrats, remembering their opposition to post Civil War military reconstruction, and Populists, who thought a large Regular Army could be used for internal repression, formed a powerful alliance against Hull's bill. ${ }^{19}$

On April 6, the militiamen and their friends destroyed the bill. Many speakers spoke of the moral virtue and fighting spirit of the Volunteers. It was felt that enlarging the Regular Army was to be the "first step toward militarism and the destruction of our cherished freedoms." 20 At the beginning of the second day of debate, Hull surrendered to the opposition and the House voted 155 to 61 to send the bill back to Committee on Military Affairs. ${ }^{21}$

On April 19, Congress by joint resolution authorized armed American intervention. It was declared that Cuba should be free and independent and that the U.S. had no desire to

18 Graham Cosmas, p. 91 . For the complete text of the Hull Bill see Congressional Record, 55th 2nd session, 1898, X+XXI, Pt. 4, p. 3676.

${ }^{19}$ Congressional Record, 55th session, 1898, XXXI, Pt. 4, p. 3637.

20 Ibid., pp. 3624-3625, 3627-3628, 3634-3636 All contain feelings of fear that the National Guard would not survive if the Hull Bill was passed.

21 Ibid., pp. 3621-3626, 3630-3632, 3640-3644. 
annex Cuba. On April 25, Spain ignored a final American demand that it leave Cuba, and Congress formally declared war. ${ }^{22}$

On April 19, the House and Senate introduced a bill to create a Volunteer army. It authorized the President to raise a temporary Volunteer force of 60,000 to serve for three years or for the duration of the hostilities and to be disbanded immediately upon restoration of peace. The Volunteers would adopt the same organization, have the same regulations, and receive the same pay as the Regulars. The President also could set a quota for each state, based on the population. ${ }^{23}$ The House passed the bill on April 20 and the Senate on April 21 but the final version reduced the term of service to one year at the urging of businessmen, and authorized the President to raise United States Volunteer units from the country at large. ${ }^{24}$

On April 23, President McKinley issued his first call for Volunteers under the new law. Instead of 60,000 troops he requested the states to provide 125,000. Militia officers could not be denied the commissions and opportunities that could get them promotion, glory, and prestige. Calling for 125,000 equaled or exceeded the entire enlisted strength of the National Guard. 25 Secretary of War Russell Alexander Alger telegraphed each state governor designating the portion of the 125,000 men the state was to provide. He specified the number of regiments, companies, or batteries each state was to organize and

22 French E. Chadwick, The Relations of The United States and Spain : The Spanish American War. Vol.1 (New York : Charles Scribner's Sons, 1911), p. 127-146. Ernest R. May, Imperial Democracy :The Emergence of America as a Great Power, (New York : Harcourt, Brace, and World, 1961), p. 158-159.

${ }^{23}$ Graham Cosmas, p.101 and The New York Times, April 19 and 20, 1898.

${ }^{24}$ Congressional Record, 55th Congress, 2nd Session, 1898, XXXI, Pt. 5, pp. 4113, 4116, 4182.

25 The New York Times, April 18, 19, 22, 23, 24, and 26, 1898. 
urged that they be recruited from the National Guard "because they are armed, equipped, and drilled." 26

The Regular Army could not fill its ranks quickly enough because of so many needed. The Volunteers had easier discipline and there was the chance to serve with friends and neighbors under known commanders. The size of the Regular Army was also modestly expanded to 61,000 . By the end of May, the Army had enlisted only 8,500 of the 36,000 men needed to bring its formations to their war strength. When the Regulars left the country, most went into action with less than half of their needed manpower and it was not until after the Cuban war was over in late August that the Regular Army realized its authorized numbers. 27

On May 1, 1898, the United States Asiatic Squadron, made up of unarmored cruisers under the command of Commodore George Dewey, attacked a small flotilla of Spanish ships in Manila Bay. The Navy planned this as a diversion to keep part of the Spanish fleet out of the Cuban area. In the few hours of combat, Dewey sank or set fire to every Spanish ship. He telegraphed Washington that he could take Manila if there were troops sent to occupy it. 28

On May 3, at the request of Secretary Alger, Commanding Major General Nelson Miles submitted a plan to dispatch 5,000 men to Manila to secure the Philippine capital. The force was made up of two battalions of Regular infantry, three Volunteer infantry regiments, and two Volunteer heavy batteries. All the Volunteers were drawn from California, Washington, and Oregon, and they were to assemble at a West Coast port for

26 Graham Cosmas, pp. 109, 114.

27 The New York Times, May 1, 7, 9, 18, and 26, June 5,1898. and Graham Cosmas, p. 113.

28 Russell A. Alger, The Spanish American War, (New York : Harper, 1901), pp. 318-324. French E. Chadwick, The Relations of the United States and Spain: The Spanish - American War, vol.1, (New York : Charles Scribner's Sons, 1911), pp. 89-93, 154,156-157, 170-171, 211-213. 
transport. On May 4, President McKinley directed the concentration of men to be at San Francisco. On May 13, when Dewey requested the dispatch of a garrison to Manila, all the troops were gathering at San Francisco. 29

Oregon was requested to provide 1,352 men, including 56 officers. The state furnished one regiment of infantry, two batteries of light artillery and one company of engineers. The character of the rank and file of the men were as follows : Average age, 24.98 years; average height, 5 feet 7.68 inches; average weight, 148.5 pounds; married, 89; students, 256; clerks, 141; lawyers, 15; bookkeepers, 15; carpenters, 29; farmers, 123; laborers, 175; mechanics, 66; teachers, 28; merchants, 34; ministers, 2; college graduates, 114; employed when enlisted, 1190; members of a church, 531. The regiment was the first to land in the Philippines, the first to enter the walled city of Manila, and the first to return to the United States. The unit served in the Philippines from August 13, 1898 to June 22, 1899 , and was one of the three regiments that performed the difficult and dangerous duty of provost guard in Manila. The unit participated in forty - two battles, engagements, skirmishes, and march a total of five hundred and thirty - eight miles in a three month period from the middle of March to the middle of June, 1899.30 The diary of Corporal Chriss A. Bell provides a first - hand account of the Oregon regiment's service and offers a look at how at least one enlisted man viewed his military experience.

29 Russell Alger, Ibid., p.326. French E. Chadwick, The Relations of the United States and Spain : The Spanish - American War, (New York : Charles Scribner's Sons, 1911), vol.1, 208-21 1; vol.2, 363-364. Nelson A. Miles, Serving the Republic, Memoirs of the Civil and Military Life of Nelson A. Miles, (New York : Harper, 1911), p. 271.

30 W. D. B. Dodson, Official History of the Operations of the 2nd Oregon Infantry United States Volunteers in the Campaign in the Philippines, (San Francisco : Hicks - Judd, 1899), p. 7. 


\section{CHAPTER III}

\section{MAY 2, 1898 TO JUNE 3, 1898 : FROM OREGON TO HAWAII}

This chapter covers the period from the beginning of May to the beginning of June. The Oregon Volunteers were mustered into service when Bell starts his diary. The Oregon Volunteers stayed in Camp McKinley in Portland until May 16. They departed to San Francisco by train. They were in their new camp at Presidio in San Francisco for seven days. Three ships set sail on the 24th of May, on the first armed expedition to travel that far (6700 miles) by sea from the U. S. for the sole purpose of conquering and occupying foreign soil. The name of the ship that Bell is traveling on is the Australia. They were sailing for the Hawaiian islands and Bell wrote much about the conditions of so many men on a small ship at sea, their food, and ship life. It took them nine days to sail to Hawaii and this chapter comes to an end when they reach Hawaii.

In the war during this time, period, George Dewey left Hong Kong for the Philippines on April 27, and arrived in Manila Harbor on April 30. On May 1, he attacked a ten ship Spanish fleet under Montojo who had anchored his ships close to the protective firepower of his forts. Dewey destroyed the Spanish fleet in Manila Bay and blockaded Manila. Spain sưrrendered with 350 casualties. The Americans had one - a death due to heat stroke. Dewey had no forces to occupy Manila and waited for the forces to come from San Francisco.

In Cuba, the first American combat fatalities in naval actions occurred at Cuban ports of Car'denas and Cienfuegos on May 11. Winfield Scott Schley had established a tight blockade around Cuba and attempted to stop the Spanish fleet from sailing to Cuba. 
The Spanish squadron fleet commander was Pascual Cervera, on May 28 his squadron was blockaded in the harbor of Santiago de Cuba by the U. S. Flying Squadron commanded by William T. Sampson. By the end of May, the American fleet is there to make sure the Spanish fleet can't get out. It proved to be too dangerous to sail to the Spanish fleet and engage it because of the Spanish control of the forts surrounding the harbor. The U.S. Army had to come down and take the forts. On May 15, Lieutenant Colonel Theodore Roosevelt arrived in San Antonio, Texas, to train with the Rough Riders for attacking Cuba.

\section{The Diary :}

May 2, $1898:$ Co. H. called out for actual service in war against Spain. Oregon's quota of troops are made up of some regiment of Infantry. The Gov. \{Lrd.\} [William P. Lord] called for volunteers from the organized militia of whence there will be nearly enough to to make full regiment. ${ }^{1}$ Transported at Armory. With my usual luck I was pluck [plucked] for guard duty.

May 3, 1898 : Early this morning [we] marched from Armory to Camp McKinley, which is the old Irvington race track. ${ }^{2}$ There are already some troops here from different parts of state. Co. $\mathrm{H}$ is to retain its old officers. Cap. McDonald [Charles E. McDonnell] 2nd Lieut.[1st Lieut.] Aug. Gritzmacher \& 2nd Lieut. James McKinnon. We also recruit

${ }^{1}$ C. U. Gantenbein, The Official Records Of The Oregon Volunteers In The Spanish War And Philippine Insurrection (Salem, OR : J. R. Whitney, 1898), p. xii, 26. Hereafter cited as C. U. Gantenbein. The state furnished one regiment of infantry, two batteries of light artillery, and one company of engineers. 56 officers were included in the total of 1352 men in the Second Oregon U.S. Volunteer Infantry.

2 John Nance, "Oregon In The Philippines," Oregon Humanities, (Summer 1991), p. 4. Hereafter cited as John Nance. The old Irvington race track is Irvington Park now called Irving Park. It is on the east side of Portland located at N.E. 7th and Fremont. It was filled with 4 man tents and became a popular site for local residents to visit, picnic, and observe the twice daily drills and occasional band concerts most likely presented by the regiment itself. 
our own Co. This is a compliance the honor given our company.alone because of our outstanding (enlisting of men) about $95 \%$ of our old members' present will enlist. The others we will recruit from around Hillsboro \& Forest Grove .

May 4 to 16,1898 : Camps all to bed and running smoothly. Grub as good as could be expected. Girls thick every evening. Cake o [and] pies etc. in abundance. I have received corporals appt. [L]ottie ${ }^{3}$ has been over several times. Leave of absence was scarce. I have finished up all my business at Rt 18 . Will have my money with them. Got buttons, belts etc. fixed for L [Luther]. Also got chain \& left.with Ms. K for a birthday also got Luther to get bouquet tie with Greens [to go] by and give on same date. R. J. H. give me a fine watch and say I can come back with them. I will not attempt to say how hard it was to leave. 4

May 16, 1898 : Broke camp at 3:30 to take train for Frisco. We are off at last. Portland people just began to realize that we are going. Our march from camp was to 3rd St. up 3rd to 1 st \& Stark, Stark to Morrison, Morrison to 6th, 6th to depot. Great motion all the way. ${ }^{5}$ Ladies of different churches had prepared lunch sufficient to last to Frisco. Forgot to mention that Physical exam--[It] was very severe about $21 \%$ failed. In our Co. only $10 \%$ [failed]. We left at 7:15.

3 Lottie is his girl that he will write often to and tell about,a last name is never given and was never found.

4 John Nance, p.4. On Sunday the 15th, 20,000, a quarter of the city's population,was at the camp most likely caught up in the patriotic fervor.

5 John Nance, p. 4-5. Nance reports that thousands lined the avenues and bridges, leaned from windows and rooftops, clung to tree limbs and lampposts, not much unlike what was done 93 years later for the support of troops in the Gulf War. 
May 17, 1898 : Passed Roseburg early this A.M. ladys (sic) had hot coffee for us. Coffee again at Ashland. Stopped at Grants Pass for several hours. Traded a brass button for a fine large lunch. Some of the boys captured a barber shop and gave free shaves etc. to the boys. It is a rule of $\mathrm{H}$ co. that none shall wear a mustache. Saw some mines in operation and also saw scenery of Siskyous, but passed Shasta at night.

May 18, 1898 : Arrived in Frisco about 1:30. Gertie Manifield was at Oakland to see me She went over to Frisco with us. Ladies of the Red Cross gave us coffee \& sandwiches at Ferry Landing. We then marched to Praeside [Presidio]. Frisco people gave us a fine reception. The camping ground at Praeside [Presidio] is down near bay in and flats. Each regiment is by itself and has its own guard.

May 19, 1898 : We are settled in camp now. Camp discipline is more severe here than at Mck [McKinley]. The food is awful. Beans, bacon, hard tack, and coffee does not compare with McK [McKinley]. [Only] 1/4 of men allowed passes at nt [night] time. Because with my usual luck I was stuck for guard duty, had to pick up squad ${ }^{6}$ and put up Headquarter tents.

May 20, 1898 : Measles in camp. All are quarantine, so my luck still pursues me and I will not get a pass at all. ${ }^{7}$

Bell, Burden, Watson, Morrow, run lines at 11 am [A.M.]. Ran back at 7 PM. Bell \& Burden tóok in sights together. See the Baths, Golden Gate, Rhutes, etc. The crowd met and took supper together in evening.

${ }^{6}$ In his diary Bell notes the 8 men in his squad. They were : Roy H. Hurley, Louis E. Pickering, Julian L. Dodge, Thomas R. Mann, Joseph H. Smith, John W. Perkins, and Oscar W. Wetterborg.

${ }^{7}$ C. U. Gantenbein, p. 28-29. The measles proved to be of a mild form and did not cause more than a temporary inconveniences from quarantine restrictions, thus allowing the following men to take in sights together that evening. 
May 21, 1898 : Drizzle and rain. Letters today one from Mrs. K. [and] one from L. [Lottie] and one from the little Pratt girl. After reading L's [Lottie's] letter felt fine. Now got to do anything. Carr ${ }^{8}$ received [a letter] also that did him good. We both went out and around and then turned to camp. Pitched our tents, I had no tools but my bag and a tin can. It was raining like Hell but we were so happy that we did not notice. I must not forget what L[Lottie] said in her letter and I must not write her anymore blue even warning letters. After pitchen (sic) tent the water did not run under and we were "comfortable" I suppose our crowd who received letters [were] taken of them and of the girls who wrote them [some read them] for two hours, I know it was long after taps. If the girls know how much your [their] three dollars did us etc. I am sure they would write often.

May 22, 1898 : Sunday Platt [Pratt] ${ }^{9}$, Ranstall, Gertie Mansfield, and some of Bert Farrells [Farrell's] cousins called today Gertie, Carey, Art Wilson \& I had a lunch.

May 23, 1898 : Adjutant Curine [Crowne] ${ }^{10}$ had me take a message to Platt [Pratt] on Australia the ship we sail on. I had some trouble finding it but did so at last After that I called on manager of Clatsop Mill Co. and introduced myself having left Mrs. K letter of introduction at camp. He is a very pleasant little fellow and spent the fore noon showing me around also took me to dinner. Returned to camp around 3:30.

May 23, 1898 : Orders to break camp at 7:30 on 24th and go aboard the Australia for the Phillipirfes (sic). Spent 3 hours of the day sight seeing in the city of Frisco.

8 C. U. Gantenbein, p. 270. William Carr Morrow Co. H. 21 years, Collector, Corporal.

${ }^{9}$ C. U. Gantenbein, p. 269. Irving H. Pratt Co. H, 20 years, Clerk, 5th Sergeant.

10 C. U. Gantenbein, p. 101. Eugene P. Crowne Staff, 27 years, Clerk, 1st Lieut. and Adjutant. 
Inspected by U.S. Army officer. Wrote letter to Lottie. Mailed those written yesterday to Mamma ${ }^{11}$, Luther, \& Rich \& Hogue.

May 24, 1898 : Broke camp at 5 A.M. Col. Jackson 12 U.S.A. presented flags from Womans Emergency Corps of Oregon. The people of Frisco gave Oregon troops an ovation while marching to wharf. [We were presented with] oranges, lemons, cigars, lunch and flowers. After a long and tedious wait on dock we boarded the Australia at 4 o'clock P.M. The Australia is smallest of the transports ${ }^{13}$ but is the best fitted up and speediest. Our quarters are beneath the water line. I will be a regular "hill" when the boys become seasick. The bunks are about 2 feet wide $\& 3$ feet high,just room enough to roll in. The isles between bunks [are] just wide enough to get through one man at a time. Electric lights out of order last night [one] could not see hand in front of your face. They crowded in like pigs in a pen. Persons seemingly trying to use ugliest language possible. We lay on section all night. Expect to leave in morning. Mailing for City of Peking [we have] to take in ammunition got [that] delivery. Breakfast this morning at nine. Canned beef, $1 / 2$ total potato, once a little coffee, no hardtack or bread issued. Received a letter from home and one from Miss Reid.

May 25, 1898 : Breakfast same as yesterday. All the boys making a good natured kick about rations and accommodations. Hoisted anchor yesterday at 5:03, crossed back at 5:45. The ships heard a great nation ship, steamers, launchers, tug boats up around them all day and preceded them to the bar. The order was City of Peking with California troops,

11 Throughout the diary Mamma is the way he refers to Mother or Mama.

12 C. U. Gantenbein, p. 30. Lieut. Col. Retired U.S. Army.

13 C. U. Gantenbein, p. 30. The three transports sailing are Sydney, City of Peking, and Australia. 
Australia troops [with] Oregon boys and my dory with regulars and 8 companies of Oregon boys. We keep this position at sea, it [is] a peaceful sight to see the five steamers.keep their island positions. We left the Tarallone Island at 1:30. The coast of America probably far away in months.

It was funny to see the men after crossing like [the] bar josh about sea sickness [and being] afraid, all were shouting and singing but one by one they all grew quiet and frail and commenced looking for the rail. The first sick were unmanfully joked about it can become an common story and no mention was made of it unless it was some well known fellow. I have not been sick so far but it is too early to brag. Rations have been mienable for supper last night we had nothing but boiled bacon, boiled potato and a little coffee and hard tack. The other meals were the same except at dinner we had bean soup and canned corned beef. It is a wonder that every man on board is not sea sick with the fat pork. P. Jarmon [Jarman] ${ }^{14}$ and myself made a graft today of good meal each. We made arrangements to help the firler clean trim and fill lamp a little while each morning for a good meal each during the whole trip. We are in luck.

May 26, 1898 : Woke up this morning feeling "funny." Got up and had my tribute to Oreplunei ${ }^{15}$ then felt better. Was not ask all day yesterday but made up for it today seasick and dysentery combined. I was not half as sick as most of the boys. The sea is very choppy today. White caps everywhere. The Australia rolls fearfully. Been taking water over her bows and dipping her rails all day. It is reported aboard that one man on the Peking died yesterday. ${ }^{16}$ Not confirmed. The rations continue miserable. I got a good

14 C. U. Gantenbein, p. 281. Charles P. Jarman Co. H, 24 years, Salesman, Private.

15 Most likely a reference to defecation.

16 This did not occur. 
breakfast from the kitchen for helping with the lamps, but gave most of it to Carr Morrow who is horribly seasick. The grub is enough to make every one sick. Am corporal of the guard today. The guard is a farce.

It is funny to see the boys who are sick. They will go to the side of the boat and while there a big wave will wash over them washing them to the skin but they pay no more attention to it than if it were flowers thrown at them. We have had no water for two days with which to wash dishes or face and hands. Everybody is dirty and the dishes are filthy. Three months ago I would not have believed I could eat under such conditions, but I do it and enjoy the eating but I would give a pretty penny for a bath or even a good wash. The hole where we eat is a regular hell. No man could stay in it without being sick.

The bunks are just for enough about one above another to roll over in and for a man as tall as myself they are not long enough. Last night I was awakened by the man on the same tier as I, kicking me in the head he had his shoes on and had my hair clipped short so it hurt. I hope he can sleep on deck in a few days. Today is Lottie Birthday I hope she has her party and has a fun time I wonder if she will think of me and miss me. Her writing is very good but I'd rather see her.

May 27, 1898 : Feeling all O.K. again today. Little sleepy after being on guard all night. Immediately after I got off guard this moming went down stairs to first class bath room and used my nerve and corporals stripes for a bath. Took Carr Morrow with me and woke him in bed also woke the cook for breakfast for both of us this morning. As usual I worked for the kitchen this morning and got my dinner. It is now arranged so Jarman works one day and I the next and each gets a meal. Jarman took breakfast this morning. I washed all my dirty clothes this morning. At least I put them in the water and took them out again. Did not get them clean, will use some Christian Science on them and believe 
they are. The sea is perfectly smooth today, that is no white caps [but] there is still considerable roll. Most of the boys are getting better but Kerrigan ${ }^{17}$ has appendicitis.

The sea is a perfect blue, nothing like I ever saw in water before. When there are white caps on the waves the contrast of the pure white and deep blue makes a beautiful picture. We are slowly getting into the tropics there is a warm lulling soft sweet sound this morning I think it will be warm enough to sleep on deck tonight by tomorrow, it will be hot. My watch has been gradually losing time. I do not pretend to set it every day but will get the correct time at Honolulu and again at Manilla (sic).

The food is worse if anything, for breakfast they served one potato and one small piece of fat half cooked bacon a little slop called coffee and hard tack. The hard tack was good. For dinner there was served vegetable soup with no vegetables \& hard tack, no coffee. No meal last night. For supper we had a stew with a few potatoes and vegetables that the boys all comment on the meat being extra pink. What a comment on the meals we are getting. I overheard the following conversation between two of the crew today "Did you ever see one carry one of those two things for my country [?]" (referring to our rifles). "No I never did! Well you never will I'll be God damned if I would have a own dog of mine in the U.S. Army after seeing the way they treat these poor boys." I went to doctor Whiting last night and made a order about the food. He had already examined it during the day and said he would make a kick [protest statement] to the Colonel in the morning. I think things will be lively in the commissary department when he starts his kick and gets the Colonel started too. The three shifts [ ships] keep their respective distance about a half mile apart. It is a pretty sight on a nice day. The ship rolls far more than the likes of the others.

17 C. U. Gantenbein, p. 274. Herbert W. Kerrigan, Co. H, 21, Bookkeeper, Private. 
May 29, 1898 : All boys are well today. At least nearly all. The grub continues the same though it is better cooked. Yesterday evening, some how some way several boxes of apples belonging to the officers I suppose, were broken open and such a scramble for apples you never saw. I got my share (about a dozen) and took them down to the boys in bed. The same evening a box of figs were discovered under the bunk of one of our boys. He had bought them in Frisco. The Co. H just got after them and when young Holbrook 18 came to bed he found his figs missing.

I find my one meal a day in the officers mess a great help. It is funny to see the boys who at home would not speak of their sweethearts not only willing but anxious to speak them to those who are acquainted with her. I'll bet a penny that $3 / 4$ in the old Co. H have some girls picture with them each one ready to swear that his is the prettiest in Portland. I am finishing quotas which I started in Portland. Then I will begin the New Testament and the Christian Science Book. We boys occasionally got a chance to begat [get] fresh sandwiches from some steward. Pies are quoted at $\$ .25$ each, sandwiches $\$ .10$ each.

Today the sea has been smooth and the weather was pleasant, although there was a hard shower late in the evening. Early in the evening we passed through to [two] storms. All around us was clear and the seas smooth but away off as near the horizons we could see the dark angry looking clouds and the choppy sea. You learn a great deal of a fellows character at sea. I find that many of the fellows that I have tried to do a good turn are not willing to return,the favor in fact it seems to be every one for himself and get as much out of the other fellow as you can. Although I guess I can take care of myself with the most fellow. I wish those of us who at home who thought out this trip would be one continual picnic could see some of us fellows trying to eat the grub we get after three days. We now 
have water $\{$ cold $\}$ to wash over dishes and face $\&$ hands. I hear that tomorrow they are going to fix up a bath for us.

May 30, 1898 : Yesterday was Sunday. We had services in the afternoon. The parson seems to be a pretty nice sort of fellow. He makes a good sensible talk. He brought tears to many eyes when he referred to the fellows at home \& the duty we owed them. A bathtub was rigged up yesterday. It is about 10 feet square and 4 feet deep and the water runs in all the time, so every one can have a cold bath whenever he wants it.

The meals are awful. All that is served to a man for the three meals is not enough for me. For breakfast yesterday morning we had bacon and bread and coffee. For dinner boiled beef and a little gravy and hard tack and coffee after we had rice and sugar, nothing else and I could have eaten it all at one meal and wanted more.

In the evening I began to think how I would spend the Sunday were I at home and thought of this call would probably have made a L - . - [Lottie] and the lunch she would have set etc. We are now getting into the warm weather and I sleep on the deck after this I think. The kids are getting gay after their sea sickness and by tomorrow will be well enough to all kinds of mischief.

The City of Peking and Australia were within two or three hundred yards of each other today \& the closest they have yet been. The nights are now perfect and many a time do I wish I was home biking etc. I saw my first flying fish this moming they fly much farther than I thought they could. They do not leave the water very far but must fly at least over 60 yards. They are white underneath and look like a whole streak in the air. The rumor today is that we will all have to be vaccinated. Wont there be a lot of sick boys here if that is so [?] The water is getting poor. I do not believe the tanks were cleaned before we left as it would remain sweet longer. Today is Memorial Day. We have service. I wonder what the folks at home are doing and I wonder if the folks at home will think of us today and I wonder how many of us will be alive next Memorial Day or if our graves will 
be decked with flowers by the folks at home. This Spanish war is not what it is cracked up to be in many ways. 19

We had several speeches today one by Gen. Anderson, one by Col. Summers ${ }^{20}$ one by Major Gantenbein 21 and one by Lieut. Col. Fran [Yoran] ${ }^{22}$ I was given a squad of 10 troop to look after today. I have to see that they keep their guns, clothes, bunks in a good condition. Most of my men are terrible and take no pride in their personal appearance. In fact I'll have a hard time with them.

May 31, 1898 : Inspection this morning. We are now only two days from Honolulu and it is getting very warm and uncomfortable the hot weather will be hard on me I think. The doctors have started to vaccinate our turn will come in a day or two. I suppose about the time we reach Honolulu we will be good and sick. Grub continues as bad as ever but the last two days the boys have had all they wanted. We've had vegetables, hard tack, beans or rice. We never had two kinds at the same meal and rarely have meals at the same time we have a vegetable for dinner today. Believing we had a regular roast we had coffee, potatoes, rice, and prunes. My share of the dinner was fine. I give $\$ 10$ for a good square meal with vegetables and fish. We may not be able to get ashore at Honolulu as there are two cases of measles aboard. I slept on deck last night and was very comfortable. The hole is stinking and stuffy and that to remain there even 10 minutes will give one the headache.

${ }^{19}$ Interesting perspective. One may be sure that the patriotic fever has died down.

20 C. U. Gantenbein, p. 99. Owen Summers, Staff, 47 years, Merchant, Colonel.

21 C. U. Gantenbein, p. 99. Calvin U. Gantenbein, Staff, 33 years, Attorney, Major. The author of this main reference work.

22 C. U. Gantenbein, p.99. George O. Yoran, Staff, 34 years, Publisher, Lieut. Col. 
Now that the boys are well they spend the day lounging about the deck reading and playing cards. I think the life is a very demoralizing one as each fellow seems to try and be as obscene in his language and stories as possible. I am thinking that the combination of vaccination and hot weather is going to make a whole lot of sick boys again. The Australia \& Peking stopped during the night and [the Sydney] cleaned flew so the Sydney got a good many miles ahead of us but we are overhauling her today and will probably catch her this evening.

June 1, 1898 : Nothing much happened today except sighting of a large steamer early in the morning. As soon as she discovered us, she headed directly toward us. The officers did not recognize and of course the boys thought she was a Spanish Man of War. We sighted the islands in the afternoon and entered Honolulu Harbor about 7 P.M. Such a reception will always be remembered. I believe everyone on town was down to the dock all eager for the news. ${ }^{23}$ No shore leave was granted this evening. Think cigarettes, etc. were tossed aboard in confusion. My bed was horribly soiled by boys dropping bananas on it in the scramble.

The islands were somewhat of a surprise. The sky out there is the most jagged and broken I ever saw. The hills are not as I expected and with tropical trees but once bare and brown and dry. The sides of the mountains were narrowed by crevasses formed by flowing lava. The mts.[mountains] came clear to the sea except in a very small strip. This strip is beautifully cultivated and, being planted in coconut, banana, and other tropical trees.

Honolulu harbor was also a surprise being small and at low tide almost surrounded by reefs. The town is about 25 or 30,000 . Here there seems to be a big scoop taken out of

23 C. U. Gantenbein, p. 33. Gantenbein states that Honolulu citizens had two reasons for this reception. One was the American patriotism that still owed allegiance to the great republic. The second was that if the annexationists would become involve in foreign difficulties the United States had no alternative but annexation. 
the mts [mountains] making a small semicircular basin probably 6 miles long and 3 miles wide. It is beautifully cultivated. The first people I saw in reaching the wharf were Dekum, McIntosh,and Adams. ${ }^{24}$ Some Oregon people came out in a small boat to meet us. They raised an umbrella on which was painted Oregon.

June 2, $1898:$ I got shore leave this morning at 10 and reported again at 2:15, then got off again [superstitiously\} [surreptitiously] until seven. First went to Oregon headquarters for Oregon \& Wash at office [with] Mr. Adams. The sign on front of headquarters was a large American flag from the lower edge corners of which was suspended a pair of rubber boots and also a large umbrella. Owing to having headquarters the Or. \& Wash. boys food [is] better than others especially the Oregon.

After a cleanup I went with the Stanford boys who were being looked after by the Stanford boys of the Island. They got the two largest rigs ${ }^{25}$ in town and started us out first putting all kinds of fruit in wagons. We went to Executive bldg \{formerly palace\} and other government bldg and then went to Wrights villa in Waikiki beach [which is] a suburban resort about 4 miles out of town where there are begant [several] bath houses etc. Took surf bath. Water warm and fine. Ate dinner at villa. Had some pictures taken. Met some more people. Streets of Honolulu are very narrow but smooth [much like a] kind of concrete. Business buildings are nearly all of brick. A few [are] of coral rock covered with concrete [and] all [are] two stories. Stores open at 7 or 8 and close at 4 or 5 Everybody rides in carriages or horseback. Ladies ride straddle. The homes are of no styles. Either old colonial or what I call beach cottages. All set back from the street in large yards amid tropical gardens of all kinds. All together the most beautiful homes I ever

24 C. U. Gantenbein, p. 207, 290. William MacIntosh, Co. E, 18 years, Clerk, Private. Waldo J. Adams, Co. I, 22 years, Student, Private. No record found of a Dekum or one that fits close to the spelling of Dekum. 
saw. Each house has a large lanai or porch which frequently is inclosed by a screen and nearly always used as dining room.

The Kanakas are lazy good natured folk not unlike our Indians or a cross between an Indian or Negro. The white people are nearly all rich. Young men receive good salaries but living is high so can save but little. All classes of natives are very immoral in fact have no morals. It's also a bad place for all young from all accounts. The people are more than hospitable. About $\$ 3,000$ was raised for entertainment of troops of this the share of our expedition was poor.

Everything was free. Street cars, cigars, sodas, meals, baths, busses, in fact we owned the town. Go to a store, buy something, start to pay, and some stranger would step. up and take your check. At one hotel where meals were served ordinary prices all that was charged was one brass button. By passing along the street or riding on cars and strangers who afterward proved to be of the wealthiest people on the Island would come up and insist on taking you home to dinner. Everybody was willing and answers to lend his bike or rig or both. The swell clubs were all thrown open including five terms club where we were served etc. Politics were thrown aside and everybody went to entertaining. The congress was adjourned so the boys in the night use the desks to write home.

President Pole ${ }^{26}$ met and talked with any and all who cared to meet him. The birds, fishes, animals, trees, and fruit were were to me wonderful. Fishes not only strange in form and none but all the colors of the rainbow. There is no crime here and tramps doors remain unlock at night. The city was one sea of American flags everybody wants Annexation and they ought to have it. If it is not accomplished before I return every little thing that I can do toward it I certainly will. ${ }^{27}$

26 This president was a territorial govemor of the Hawaiian Islands.

27 Bell writes a bit prophetically here. After Queen Liliuokalani abdicated in 1893, foreigners in Hawaii set up a provisional government with a view to negotiating for annexation to the United States. President Harrison sent an annexation treaty to the Senate, but President Cleveland, on his coming to 
The drive out to Waikiki was more than beautiful first through rows of beautiful homes then between forests and groves of tropical gardens flowers and fruits of all kinds in bloom. Birds to me beautiful and strange living colors and notes filling in and out around the branches. The baths cannot be surpassed the water being so warm that you can stay in all day without becoming chilled in fact bathing by moonlight is the fad. Everybody swims Men, women \& children. The swimming power of Kanaka kids are wonderful. They surround the streams and beg for money to be throwed [thrown] in the water then there is a grand scramble and dive and they always get this money. I never saw one fail. Although the money may have struck the water 10 feet from them. I missed carving through the surf. Mrs. James and husband and a young couple that I met have been more than kind Girls here are all fine, lazy, healthy looking, and bright girls but only a few are more than ordinarily nice looking. Did not see one that would compare with L. [Lottie]. Oh I wish she were here. How she would enjoy it.

June 3, 1898 : Today was the great day in Honolulu. A spread was set to which there sat down about 2,300 soldiers. The spread consisted of meat, salad, coffee, sandwiches, fruit, and sodas. All the wealthiest and best people in Honolulu ate with the boys. One man with a 6 million etc. (wealthiest on the Island) served the sandwiches. There was no speech making the people simply got in and in and did things. after the lunch we had liberty till night. I went around town and to the Times club. I also met Mr. James who went around with me and invited me to dinner at Wrights villa out at Waikiki beach. There met a half dozen nice people and took a swim and enjoyed a thoroughly fine dinner. Returned to town at night. The moonlight ride in was the finest I ever saw. I also saw a lunar rain lovely. The moon is bright enough at full moon to read by. Dinner was served on the lanai or porch at rear of house overlooking ocean. The waves rolling up and soft 
warm breeze from Diamond Head in the distance made the dinner more than enjoyable. The vegetable from which Poi, the native dish is made was spread and was very good tasted something like a dumpling. I had one dish of Poi which is not at all bad when eaten with milk and sugar. Mr. James had taken a lot of pictures of the troops and boys and [I will] send a copy to mamma and Lottie. Lottie's will be sent to Astoria [with] Mrs. Kinney [I] wonder if she will get them. I dropped out June 2 nd \{some way no I did not\}. 


\section{CHAPTER IV}

JUNE 4, 1898 TO JUNE 30, 1898 : HAWAII TO THE PHILIPPINES

On June 4, The Oregon Volunteers left Hawaii and travelled to Guam. There is much written by Bell of ship life and the monotonousness of it. The ships reached Guam on June 19, and Bell described the engagement that took place that enabled them to take the island. The ships left Guam on June 22 and travelled to Manila. The chapter ends when they reached Manila on June 30.

Much action occurred in the month of June in Cuba. On June 6, Sampson's Atlantic Squadron bombarded Santiago with a heavy naval barrage. Sampson established a coaling station at Guantanamo Bay and set up a base and fought off a three day attack by the Spanish, securing Guantanamo Bay in American hands. 16,000 men sailed from Tampa and reached Cuba on June 17. They landed at Daiquiri and Siboney, 15 miles east of Santiago to secure bases for an assault on Santiago.

The first American offensive of the war in Cuba occurred on June 24. Joe Wheeler sent the Rough Riders into battle at Las Guasimas, which guarded the road to Santiago from Siboney. After winning the battle, Wheeler pushed toward El Pozo Hill, seven miles from Santiago.' Spanish reinforcements were at the same time coming to Santiago from Manzanillo, 45 miles away. On June 30, preparations were made for a July 1 attack on El Canay, San Juan Hill, and Kettle Hill. 
The Diary:

June 4, 1898 : Left Honolulu under escort at 10 o clock. Before leaving women came aboard with wreaths and put them around the neck of each fellow. Fruit of all kinds, cigars, cigarettes, etc. were given to us in abundance. In short the leave taking was in keeping of the reception and the reception was far ahead of anything we experienced or thought of. They surpassed Frisco and Portland 10 times over.

June 5, 1898 : Sunday Got a Breakfast at 10. Rumor says only two meals a day, all of which I do not like. Hope it is not so. I suppose this is Lottie's last Sunday in Portland. I wish I was there to spend it with her. I wonder what she wishes.

June 6, 1898 : Cut down to 2 meals a day. Up at 6, coffee at 7, Dinner at 10, supper at 6 not half enough at either meal done in about every day at 9:30. We will be marched each day and at end of trip. Officers will know standing and a report will be made to Colonel. I shall try and lead our class think it will please the folks if I could make such a report. This two meal a day proposition with only half enough at each meal N G.1 It was rumored today that we will first go to the Ladrones about 1200 miles this side of the Phillipines (sic) and attempt to capture some Spanish gunboats and a town called Guam ${ }^{2}$ for a cooling station. The report is that about 300 Spanish soldiers is stationed there.

June 7, 1898 : Today is Marian's birthday I would like to see her. For breakfast today we had rice half cooked. The coffee is so bitter that I cannot drink it because it

1 Most likely means no good.

${ }^{2}$ C. U. Gantenbein, p. 34. On June 4 sealed orders had been opened directing Captain Glass of the Charleston to go to the Ladrone Islands and capture Guam which is the largest of the Ladrone Islands. There was a controversy over how many soldiers would be found there, it was figured by the men that there would be enough for a fight. Calling Guam a town shows the geographical ignorance of Bell and most likely of many of the men. 
makes me sick. 20 cases of Measles [measles] on board and seem to be spreading.

June 8, 1898 : Read Cap. Courageous ${ }^{3}$ today. The position of ships is changed it now is : Peking, Charleston, Australia, and Sydney. We were assigned squads yesterday according to heights. My squad is Hurley, Dodge, Smith, Bell, Perkins, Mann, Rickhaving, Wattenberg. ${ }^{4}$ The weather is still fine and the grub as poor as ever. A very noticeable feature of the tropical climate is the short twilight at 7:30 the sun sets and by eight it is dark.

A few evenings ago we had the most beautiful moon rise I ever saw. In the east was a dark bank of cumulus clouds from taking which the moon slowly appeared fast tipping the edge of the clouds with silver or gold. The moon was full and when it appeared it shot a path of silver clear to steamer. The sea continues smooth but the darned old boat rocks all the time. I must describe another meal wishing to continue appendicitis. Mess is as follows [:] Onions stewed or boiled $1 / 2$ or $3 / 4$ for each man, $1 / 2$ boiled potato, a small juice of boiled beef, possibly a cup of tea (that's what they called it anyway) those who got no meat got a amiable spoon of beans. Prunes as dessert in number eight. I was so hungry that I offered to trade prunes for beans even 1 prune for 1 bean but found no takers. The onions were only half cooked hardly that warmed through. I am thinking the noncom school is a farce. Half the boys do not learn the lesson and the instructor does not seem to notice what the boys say and allows incorrect answers to brass.

June 9, 1898 : Same old story. Saw Southern cross in evening. Water near ship

${ }^{3}$ Captains Courageous by Rudyard Kipling pub. 1897 tells of a story of fishermen on the big sea and was probably most fascinating for Bell because of his sea trip.

4 This is the same squad as his listing on May 30. 
was lighted by phosphorescence. Some time to sunlight we cross the 180 meridian and lose [actually gain] a day. We go to bed Thurs $9 \&$ wake up Sat 11 . Wattner [Noltner $]^{5}$ and I get a supper from Morrow \& Watson if we are in it when we get home if not we give supper. We had some nice music evening by boys songs National airs $\&$ home songs.

June 10, 1898. Skipped.

June 11, 1898 : We are nearing the Carolinas where there are some Spanish gunboats which Charleston will probably meet. We may see some service hope [we will]. Me [I saw] Pear Carters brother yesterday. He has been sick all the time since leaving Frisco and was brought on deck to stop had to give up my place to him. We struck up conversation and found out we had met before. Weather is all fine. Hope it will remain so. We of course are now in the Eastern Hemisphere. Wonder when we will go into Western again.

Inspection tomorrow. The articles of war were read to us today they are very severe and allow a man a very bitter feeling. I find that the fish I have been calling dolphins are not, but are Black fish. After tomorrow night no lights will be displayed in account of the nearness to the Carolinas. Our average rate of speed since leaving Honolulu is a little over 10 miles per hour as we make about 230 to 245 a day. From S. F. [San Francisco] to Honolulu we made about 300 to 320 per day but we were not accompanied by the Charleston. Her coal supply is such that we cannot steam faster and make such a long trip without revealing [ourselves] and there are no ports at which we can coal during war times after leaving Honolulu.

As the rumor goes the object of capturing ports etc. in the Carolinas \& Ladrones is as much for the purpose of obtaining coaling stations for future expeditions as for hurting

5 C. U. Gantenbein, p. 269. Fred Noltner, Co. H, 24, Stenographer, 1st Sergeant. 
the Spanish cause. I understand that besides the rumored gunboats at the Carolinas there is a fortified city which we are to attempt to take. According to same rumor the fortifications are quite modern and if a size sufficient to accommodate 700 men but it is not known how many men Spain has there.

Life on ship board has very much of the monotonous in it. Day after day one crowd of boys will play cards, another read, another sleep, and another continue at cut up. I think it is a very good place for character study. The noisy foulmouthed sleeper is very much in within. I never realized before how much the presence of girls did toward making more gentlemanly in their actions. Neither did I believe there were so many even of what are termed the best families who were only gentlemanly because of the presence of girls and who are naturally coarse in thought speech and action.

June 12, 1898 : I commenced keeping the diary on the 26th from the 2nd of May to the 26 th is largely from memory assisted by diary of Hardee. ${ }^{6}$ Today is Sunday. We have inspection at 11:30 everybody cleaning guns this morning. The parson and Gen. Anderson's son took exercise with my squad this morning. Weather still fine sea still smooth grub still rotten. The Co. which messes next to us found tobacco in the coffee this A.M. however we are getting used to it and you can shit your way and drink the slop and imagine it is anything \{except coffee\}. Have finished reading Museum Daydam. ${ }^{7}$ Officers went on a tear last night. I do not know what the celebration was for but the punch bowl was open and nearly every officer on board was hilarious. Charlie Mc [McKinnon] kept straight.

6 What the editor did was to take the diary that Bell added on at the June 12 point concerning the dates May 2 to 26 and put them with the original diary entries. This would prevent having two sets of the same dates at different points in the diary.

${ }^{7}$ Not sure what is being referred to here as to title of a book or author. 
The preacher gave us a fine sermon today. Like him better the more I see of him. He is to start Sunday School, if possible think I will have to join and help all I can for he has a hard work before him. 800 men without the refining influence of a single wife, mother, sister or sweetheart except the memory of those at home, is not the best and most encouraging place for a pastor. For immorality in thought and speech seems to be the pride of nearly all.

I must describe another meal this time because it was good, a regular first camp and with the usual ones. Grub made of beef, beans and rice that was fine, potatoes boiled, beef boiled, squash stewed, canned peaches, cigars and tobacco. The peaches were not given by the U.S. but were brought from Co. guard. The other Co.'s had none. The cigars I understand were a treat from one of our officers. The boys say that at Honolulu there was a quantity of fruits, coconuts, cigars, cigarettes etc. donated to the boys which we can get if we pay for it. Somebody is making a great "graft" I think. Lieut. Platt [Pratt] is head of commissary dept. but cannot believe he would make a graft from the boys. Something may be behind if we return by way of Honolulu. Furman [Freeman], Jarmon [Jarman] Morrow, Burden, Watson, O Neil ${ }^{9}$, Roy [Hurley] and myself form a push that hang forth well together. I have been wondering today if the fire at old K's mill will affect L [Lottie]. If it will make the old man meaner to her. Some of the boys seem to think we will go to Hong Kong. Time will tell, hope we will.

June 13, 1898 : This is hottest day we have had. We were all compelled to stand on clothing today, The festive are back had been discovered on some of the boys. 10 The

\footnotetext{
${ }^{8}$ C. U. Gantenbein, p. 273. Frank Freeman, Co. H, 20 years, Student, Corporal

${ }^{9}$ C. U. Gantenbein, p. 276. Robert O Neil, Co. H, 26 years, Lawyer, Private.
}

10. The reference is made to lice. 
cops have been busy all day, looking after and drilling squads finding where they slept etc. Our push make it a rule to divy (sic) up anything we get in the way of eating.

June 14, 1898 : "Oh would some know the Gifte gie us; To see ourselves as others see us." So said Burns in looking at the ladies bonnett. 11 So said the boys today when the Drs. discovered lice on ticks, blankets, etc. They made an inspection of the boys who sleep on deck. Our quarters now well policed but it takes a good hours work down in the hole every morning for Burden and myself. I exercise my squad every morning from 7:30 to 8 in calisthenics. I had to call down young Holbrook this A.M. for bothering the squad while at drill. It did him good. We are allowed to eat from the commissary canned fruits. Watson, Morrow, Jarmon [Jarman], Freeman, O Neill (sic), Burden, Roy and myself get 3 cans nearly every morning.

The sunsets and evenings are beautiful here. They beat anything I ever see at home. It is attack. We do not go to the Carolinas for we are past them. Cap. McDonald told me this morning that we would reach the Ladrones at Guam about next Sunday \& that we would probably see active service there. This is another hot day but the heat does not oppress me as I thought it would. Yesterday Coleman was sleeping on deck and about half past three the boys got a pair of blankets, doubled them, and put them on him. He slept under them for $3 / 4$ of an hour or more before he woke. Talk about a sweat box, it is not in it with a pair of blankets 15 degrees North of the Equator. Sunset last night behind a bank of clouds just before going below horizon there was a rift in clouds through which sun broke it looked exactly like a large flame from a burning ship. After noncom lesson today

11 The poem is "To A Louse ; On Seeing One On A Lady's Bonnet At Church." \{pub. 1786\}. The line comes from the eighth stanza of the poem and goes : $O$ wad some Power the giftie gie us

To see oursels as others see us!

It wad frae monie a blunder free us, An' foolish notion : What airs in dress an' gait wad lea'e us, An' ev'n devotion! 
the Major told noncoms that $\mathrm{Co} . \mathrm{H}$ was the only $\mathrm{Co}$. which had been perfect straight through. Col. Summers also gave us a send off in regard to condition of our quarters.

June 15, 1898 : I am Corporal of the Guard. Had the pleasure of calling down the officer of the day. He wanted to have me as Corporal of the Guard take prisoners out and do general police work. I objected saying Corporal of the old Guard should do it. Carried my point. The prettiest colors in the sky I ever saw one large ship looked like pearl of different colors. Brown the "fat boy" of Co G [F] 12 fainted last night something of heart trouble he probably will recover but may not. He to bathe twice each day in tank. Vaccination has begun to take but not hard. Officer of Guard Lieut. Hartman ${ }^{13}$ of day Cap. Gadsby. ${ }^{14}$ Latitude today 13 N. Long. 163 E.

June 16, 1898 : Long. 159-04 E-14-17 N. Tired out today [due to] no sleep last night. Corp. of Guard and I arrested 5 men last night for sleeping on post he let go because Gadsby would not prepare charges [against] one of his own men caught. I had a successful time on guard done good boxing a man from G. Co. back to Doc. Smith. He lasted about 2 minutes when he quit due to a bloody nose.

June 17, 1898 : Policed boat today under Capt. Heath. ${ }^{15}$ The officers $\{$ naval came aboard. The Australia it is a pretty sight to see boat lowered from Charleston and the

${ }^{12}$ C. U. Gantenbein, p. 219. Elbert K.Brown, Co. F, 22 Years, Corporal.

13 C. U. Gantenbein, p. 170. George A. Hartman Jr., Co. D, 20 years, 1st Lieut.

14 C. U. Gantenbein, p. 260. William Gadsby, Co. G, 39 years, Captain. Resigned due to sickness Dec. 31898.

15 C. U. Gantenbein, p. 103. Herbert L. Heath, Co.A, 33 years, Captain. Wounded in action at Marilao Apr.11, 1899 and wounded at Maasin May 4, 1899. 
white Jackets row to our ship. The Cap. of the Charleston brought plans or maps aboard and had a consultation with our head officers suppose in regard to the expected work at Guam. It is the belief of all the officers that we will see active work. After the officers came aboard our ship the Charleston dropped target over board and practiced with her $8 \&$ 6 inch guns. They make a horrible war. Would not care to see one come my way. Stopped a quarrel today will probably have to take in court.

June 18, 1898 : Something in the grub today knocked out most of the boys [and] gave them bad case of dysentery. We think it is the meat that had become tainted. The [cook] threw remainder over board today. We will have to use canned beef now. I had on gloves with Dud Newt [Judge New] ${ }^{16}$ last night, he became rattled and tried to rush me but got worst of it. Several of good matches today. We sighted land today. Some small island not on chart. 17 Guns inspected today. Everyone is looking forward to beaching Guam tomorrow.

June 19, 1898 : Sunday. Showers all day. Our 3 mate went aboard Charleston to pilot her into harbor. Do not know whether we go ashore or not. But think not. We had 3 good meals today. I was writing letters during church time. I have finished all I am going to before we reach Guam. I will add some then. I hope those long letters will not tire the folks. The home letter is of course O.K. but the one to L [Lottie] may make her tired. The parson on the Peking went aboard the Charleston. I think he was a missionary at the Ladrones once.

June 20, 1898 : Sighted Guam about 4 this morning. Boats signalled each other by

16 C. U. Gantenbein, p. 282. Judge D. New, Co. H, 21 years, Bookkeeper, Sergeant.

17 This is one of the Caroline Islands probably Namonuito which is about 1 day sailing from Guam. 
lights and whistles several times. About 8 the Charleston started into the harbor a small shot was seen and we supposed it to be a Spanish gunboat. Was not. I think it was Japanese because earlier the fortifications raised white flag after Charleston had fired 13 shots. Last news came to Island May 9. They did not know war was declared but thought maybe it was. Will write more fully tomorrow when truth is learned. 18

June 21, 1898 : The town did not surrender last night was given until $10 \mathrm{~A}$. M. today. At that time no answer was received and we commenced landing troops. Companies A \& D landed and also 5 volunteers from each of the other Cos [Companies] in our boat. I volunteered. 10 men went from Co. H. Just after getting aboard the boats which was somewhat difficult because the harbor is so open and the wind kicks up a choppy sea. It was very rough and unsteady several of the men were seasick just after leaving the ship. I went in seeing lots.

The men went about 18 in a boat, 8 boats in a row towed by a steam launch under men helping row. As we left the ship a rain and wind storm started. We were in our short sleeves and of course were soaked in a minute as wet as if we had jumped into the bay, and the waves rolled over us. Inside of 20 minutes there was bunches of water in the boat. We were equipped as follows--Field dress except House Rations in Kasesack [knapsack] for about two days cartons filled with cartridge belts with 40 rounds of ammunition. As we reached about $1 / 2$ mile from shore on $1 / 4$ mile from 1 st party. A boat put off from shore with flag of truce. The Governor had surrendered two towns and Island. The principal town is several miles inland and has 5000 people. There were only a little over 100

18 C. U. Gantenbein, p. 35. Shells were fired from the Charleston and were met by Spaniards shells. 2 Spaniards came aboard the Charleston to apologize for not having enough gunpowder to return their salute. They were reported to be overcome with astonishment when they heard of the hostile errand to capture the Island. They were held as prisoners which they thought was wrong since they came for a peaceful purpose. They were let go with a message to the governor at Agana to surrender. 
prisoners at the end of the day fight. No one lost [because there was] no fight. 19 of course the boys joshed us for not landing. Barkus was writing but fate was not well used. Land off Island tomorrow when truth is known. Plan of attack [shown below].

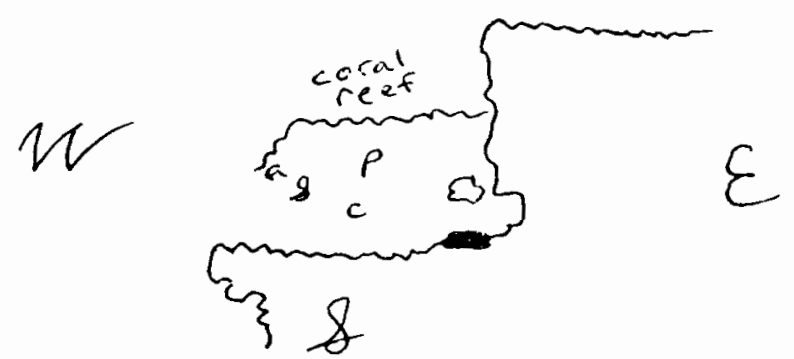

Some one on Sydney died yesterday. He was an Oregon boy from Hubbard. I think his name was Hutchinson. ${ }^{20}$ Some of [Company] L and G. boys went ashore yesterday. We leave here tomorrow for Manilla (sic).

June 22, 1898 : We left Guam at 2 PM carried away 50 old prisoners including Governor. Native soldiers were tumed loose A happier lot than the natives you never saw. They were hiked to death by Spanish Governor. It cost 25 p every time they wanted to kill a pig etc. Other things were in proportion. Yesterday after the Governor surrendered the American flag was raised over the fort at 2:55 after the bands played the Star Spangled Banner and a salute of 21 guns was fired. This was all the ceremony of taking possession after surrender of guns, ammunition and 54 Mauser rifle and 54 of some other make and 75,000 rounds of ammunition. The Governor and officers are aboard the Charleston and men aboard the Sydney.

${ }^{19} \mathrm{C}$. U. Gantenbein, p. 35 . Agana is written to be several miles inland in the next days diary entry. It is right on the coast. From the spot where Bell landed, it is about 4 miles North. At 4 P.M. fifty Spanish soldiers carrying Mauser rifles, fifty native soldiers with Remington rifles, and fifty without guns appeared on the beach. The disarming then occurred. Any natives were told to go free. The fifty Spaniards were put on the Sydney and transported to Cavite where they were held until a peace was arranged. The six officers were put on the Charleston and showed a fear that their families would not be safe without military protection in the lonely Pacific. Understandable.

20 C. U. Gantenbein, p. 368 . That is true. The name was Elias Hutchinson, Co. M, 23 years, Teacher, Private. His was the first death in the regiment. He was operated on for appendicitis a few days prior and died from the effects. 


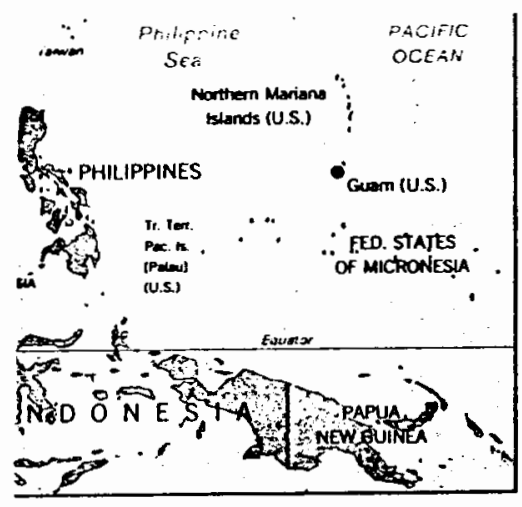

Philippine Sea
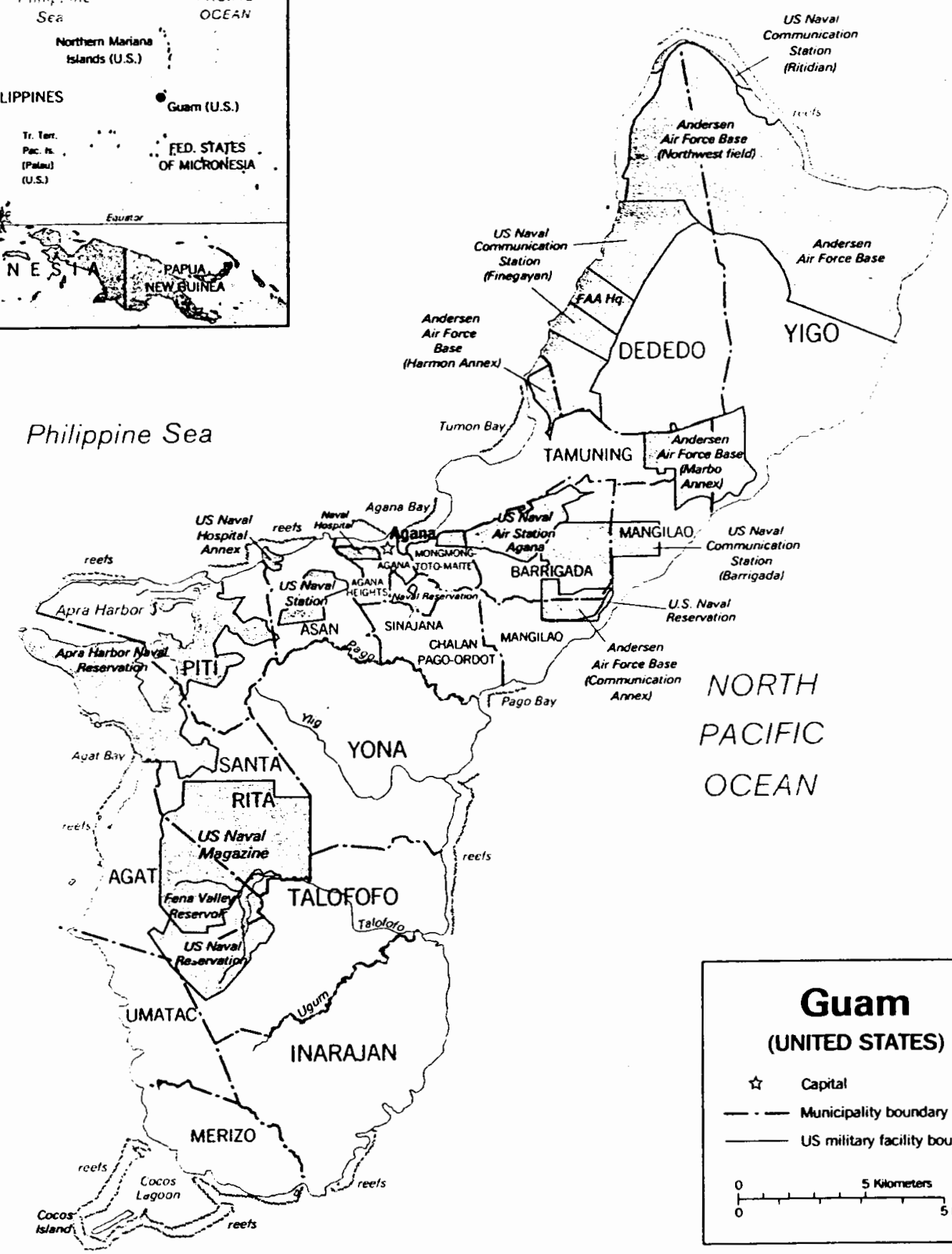

\section{Guam} (UNITED STATES)

it Capital

- Municipality boundary

_ US military facility boundary

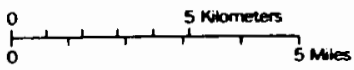

Figure 3. Map of Guam. This shows the coral reef near Agana that is in Bell's drawing. Central Intelligence Agency map. 
The natives are a peaceful lot something like a Kanaka. Their homes were raised from the ground to escape Malaria. No windows [and] no doors. A guard [Agana] is name of principal town it is 6 miles inland. The fort is a small one $50 \times 50$ built of stone. 10 feet thick The piece I have cam from where and of the Charleston's shots struck. The fort is dated 1801. The Governor and soldiers on surrendering did not expect to be captured and raised a big howlode when they found they were prisoners. The last thing done today was to haul down American flag. No attempt is to be made to keep possession. The island was turned over to the natives. There is plenty of fruit on Island but we got none because there is little little heat at this time and also because when the firing commenced day before yesterday the natives took to the woods. Most have returned but they were still scared of the bluecoats.

June 23, 1898 : School commenced again today after and interval of 3 days. We left for Valencia where we met [we are to meet] a portion of Dewey's fleet. This is rumor. But as Valencia is 300 miles from Manilla (sic) and right in course it seems probable. We expect to reach Manilla (sic) about July Ist and hope the 2nd expedition will be there soon after and we hope to receive mail from home. We are now going at Sydney full speed having found that there was sufficient coal. I will here put nicknames of some of the boys.

Frank Freeman

Don $\operatorname{Rea}^{20}$

Charlie Jarmon [Jarman]

John Watson

Carr Morrow [William C. Morrow]

Fred Nollan [Noltner]
The Human Snake

[The Human] Eel

Apex Mummy

Cynic

Conneseur (Connuser)

Titus

${ }^{20}$ C. U. Gantenbein, p. 270 . Co. H, 20, Student, Corporal. 
H. Claggett [William H. Clagett] ${ }^{21}$

Art Johnson 22

Mac Burden [Burdin]

W. Pratt [Irving H.Pratt]

Dobie Stanton ${ }^{23}$

C.[Chriss] A. Bell24

J [Julian L] Dodge 25

F.[Frederic A.] Coleman 26

W.[Wiley] W Ward27

[Edward] N. Barrett 28

[Herbert W.] B. Kerrigan

[Alfred] P. Watson ${ }^{29}$
Cupid

Splinter

Slaves

Tay

Payrole (Parole)

Deogenus (Washed in Tub)

Annanias 1st \& The Frog

Annanias 2nd \& Solomon

The Widow or Fanny

The Brownie

Boston oil Oil

Fat

21 C. U. Gantenbein, p. 269. Co. H, 21, Student, 2nd Sergeant.

22 C. U. Gantenbein, p. 269. Co. H, 24, Clerk, 3rd Sergeant.

23 C. U. Gantenbein, p. 270. Co. H, 21, Student, 6th Sergeant

24 C. U. Gantenbein, p. 270. Co. H, 24, Lawyer, Corporal. The author of this diary.

25 C. U. Gantenbein, p. 272. Co. H, 22, Salesman, Private. Discharged, no reason stated.

26 C. U. Gantenbein, p. 280. Co. H, 22, Newspaperman, Private. Discharged violation of 32nd article of war (abserft less than 24 hours).

27 C. U. Gantenbein, p. 278. Co. H, 21, Salesman, Private.

28 C. U. Gantenbein, p. 271. Co. H, 20, Clerk, Corporal

${ }^{29}$ C. U. Gantenbein, p. 279 . Co. H, 22, Student, Private. 
G.[George B.] Miller ${ }^{30}$

\section{H.[Claude] A.Hawkins ${ }^{31}$}

Joe Smith $^{32}$

[Judge] David New ${ }^{33}$

Sam Poole ${ }^{34}$

W.[William] L. Patterson 35

J. [James F.] Hill ${ }^{36}$

Lou [Louis] Scot [Scott] ${ }^{37}$

A.[Austin J.] Salisbury ${ }^{38}$

W. [William H.] Jordan 39

Sam Holbrook
Chick

The Sparrow or Tommyhawk

Modest Joe

The Prick

Robert Role

The Gladiator

Pug Hill

Laughing Jag

The Duke

Bullie the Grafter

"Weuns" or The Joker

${ }^{30}$ C. U. Gantenbein, p. 275. Co. H, 24, Clerk, Private.

31 C. U. Gantenbein, p. 281. Co. H, 23, Waiter, Private. Discharged early to accept civil employment.

32 C. U. Gantenbein, p. 277. Co. H, 24, Capitalist, Private.

33 C. U. Gantenbein, p. 282. Co. H, 21, Bookkeeper, Private. Discharged early as clerk board of health.

34 C. U. Gantenbein, p. 276. Co. H, 21, Student, Private.

35 C. U. Gantenbein, p. 276. Co. H, 27, Clerk, Private.

${ }^{36}$ C. U. Gantenbein, p. 273. Co. H, 21, Painter, Private.

37 C. U. Gantenbein, p. 277. Co. H, 21, Brickmason, Private.

38 C. U. Gantenbein, p. 277. Co. H, 23, Com'l Traveler, Private. Wounded in action

${ }^{39}$ C. U. Gantenbein, p. 281 . Co.H, 22, Clerk, Private. Discharged early to accept appointment as 2 nd Lieutenant. 
D.[A. L.] Richardson 40

J.U [Edward] Gantenbein ${ }^{41}$

A.[Albert] H. Spillings [Spierings] ${ }^{42}$

Robet [Robert J.] O Neil [O’Neil]

[Halvor H.] Rasch 43
Dirty Dan

Dutch

George Washington

Colonel Bob

Oliver Wendell Holmes

June 24, 1898 : Same monotonous old story. Stayed away from school. Brad with Rasch. Looks like a storm. Barometer very low. Good meal last night. Potato salad and prunes.

June 25, 1898 : Nothing new. I have had dysentery for two days.

June 26, 1898 : Same old story. Wind storm this evening every one sent below. Canvas sails issues cost \$1.98. I [My] guess is they are worth that much.

June 27-28-29, 1898 : Have been sick in hospital. High fever and dysentery. Nothing happened.

${ }^{40}$ C. U. Gantenbein, p. 276. Co.H, 21, Surveyor, Private.

${ }^{41}$ C. U. Gantenbein, p. 281 . Co. H, 27, Clerk, Sergeant. longer needed.

42 C. U. Gantenbein, p. 277. Co. H, 24, Farmer, Private. Discharged early due to services no ${ }^{43}$ C. U. Gantenbein, p. 276. Co. H, 19, Student, Private. 
June 30, 1898 : Met Baltimore and entered Manilla (sic) Harbor. It is fine harbor. We have 9 ships there. There are about 20 of other nations. 44

44 C. U. Gantenbein, p. 39. The fleet has been cut off from communication for almost a month and they had last heard that France and Germany might intervene. They saw a ship in the harbor that closely resembled the Baltimore from Dewey's fleet and that she proved to be. They found out there was a penned Spanish fleet at Santiago de Cuba. They went North and then traveled South into the China Sea looking for any vessel with the Spanish flag. They did come into high winds in the teeth of a monsoon, but that was the extent of any danger for that day and night. 


\section{CHAPTER V}

\section{JULY 1, 1898 TO AUGUST 15, 1898 : GETTING SETTLED IN THE PHILIPPINES}

From the beginning of July to the middle of August, many military events occurred in both theaters of war. The Oregon Volunteers unloaded their transports and based their camp about seven miles from Manila. Bell wrote many letters and did some guard duty. By the beginning of August, no attack had been made against Manila and troops were waiting for more reinforcements. Spanish and American officials on August $12 \mathrm{had}$, through Frenchman Jules Cambon, signed a peace protocol to end all fighting. The Volunteer troops waited until the 13th of August. Unaware of the peace protocol, Manila is attacked by Commodore Dewey and General Wesley Merritt, and the town surrendered on August 13. The Oregon regiment has the job of disarming troops as they surrendered.

In Cuba, on July 1, El Canay was taken after a fight of several hours. The Spanish had about 600 men in the town and General William Shafter used about 6,000 men against them. As the battle of El Canay went on, the San Juan Hill and Kettle Hill got underway. About 10,000 troops left El Pozo Hill and marched through the jungle and toward the two hills. At one in the afternoon, a twin assault was launched on both hills. General Lawton charged up San Juan Hill, and Roosevelt urged his dismounted Rough Riders up Kettle Hill. The two hills cost 1,000 dead but the Americans held the ridges of the hills over Santiago.

On Sunday, July 3, Cervera's fleet tried to go from the harbor's mouth to the open sea. The blockaded vessels spotted them and in a short time all six of Cervera's ships were aflame, sunk, or beached. The naval battle of Santiago was over. General Jose 
Toral surrendered Santiago to Shafter on July 16. About that same time, McKinley signed the treaty annexing Hawaii. On July 18, the Spanish ambassador to France asked the French government to help negotiate a truce. On the same day, General Miles got permission to send a force to invade Puerto Rico. A week later, 3,300 Volunteers were put ashore at Guanica. The landings were unopposed and the island became secure in American hands. On August 12, 1898, 113 days after war was declared, a peace protocol was signed ending all hostilities between Spain and the United States.

\section{The Diary :}

July 2, 1898 : Getting settled today.l There are here several choice Spanish soldiers [who] have prisoners. Insurgents have drawn all Spanish into Manilla (sic). We are about 7 or 10 miles from Manilla (sic). Gen. Anderson wants to attempt to take Manilla July 4th. I think we wont.

July 3, 1898 : Everything settled except Commissary department which is bum. The Barracks here are beautiful Regular tropical scene and reminds me of an old castle. The fort is very ancient. Fruit is plenty but natives are great fellows to sell. ${ }^{2}$ They do not know the value of American silver so we have a hard time making change. ${ }^{3}$ A copper will buy more than friends.

1 C. U. Gantenbein, pp. 40-41. The first person of the regiment to touch Philippine soil was Colonel Summers on the moming of the first. The first battalion of the American army to land in the Philippines was the Firs Battalion, Second Oregon Infantry, Major Gantenbein, the first company was K, Captain Worrick, the first enlisted man was Private McKenna, Company L.

2 Ibid. The men had been warned of taking water, fruit, or liquor because of the fatal consequences, unless it was strictly regulated. The water was not regularly boiled and the boys ate freely of great quantities of fruit that was offered for sale at trifling prices. The Klondike rations of the army became nauseating in the tropical climate and combined with eating the native food without any digestive preparation for it obviously produced much sickness.

${ }^{3}$ C. U. Gantenbein, p. 42. The petty character of the natives can be seen in their commercial transactions where if a soldier could be cheated in any manner, it was proper by the natives to do so 
July 4, 1898 : Very little sleep. The steamers are being slowly unloaded and we are getting a little better grub!! The barracks here are fine old Spanish style. All rooms open into an inner Court no outside entrance. Fruit is plentiful but money to get it is not. We will probably be paid in two weeks. Their small piece of money is a Centavos a copper equal to about $11 / 4$ cent. They have a 10 cent piece called ceno centavis. Their equivalent for $\$ 1$ is the Peso. They have a $\$ .20$ piece called Pesato. Uno $=$ one Dos $=$ two Tres $=$ three Quanto $($ sic $)=$ four Sinto $($ sic $)=$ five. Seis $=$ six Sieta $=s[$ seven] Ocha $=$ eight Nueve $=$ nine $\operatorname{Diez}=$ ten .

July 5, 1898 : From today we get up at 4:00 \& drill one hour--before breakfast. It is altogether too hot during the day for anything. We have a heavy thunderstorm nearly every day. There are about 2000 Spanish prisoners here captured by insurgents took [taken] in Cavite ${ }^{4}$ today.

July 6, 1898 : Lay around barracks all day. Rain nearly all time much like Oregon than any spot. Very close \& warm.

July 7, 1898 : Did police duty for butcher hard time making Coleman \& Jarman work.

July 8, 1898 : Borrowed Mexican dollar of Freeman. Went up town bought about 100 bananas paid. Freeman has money and has 22 cents left.

July 9, 1898 : Half sick today. Wrote to Mother \& Bud \& Hogue. Did not finish letters because mail went out. Hope to get letters from Lottie \& mother soon. 2nd

${ }^{4}$ C. U. Gantenbein, pp. 2,44 . The action actually occurred on July 7 when the Navy took Isla Grande and a garrison of 1300 without resistance. 
expedition expected shortly. Weather is hot. Most of the boys sick with dysentery. Boys all shirk their share of work.

July 10, 1898 : Lay around and did nothing all day. Was very sick part of day.

July 11,1898 : Nothing done. Rested was sick.

July 12,1898 : Went to drill today. Feel all O.K.

July 13,1898 : Took long walk after drill with Lee Morse ${ }^{5}$ went up beach got lot nice shells to send home.

July 14,1898 : Nothing happened. Same old monotonous routine.

July $15,1898:$ 2nd Battalion, ours, went on practise (sic) march and had target practice. We went out and about 3 miles \& the point beyond the Navy yard. We had battle formation also.

July 16, 1898 : Lay around quarters most all day. Got my old blue uniform. Rumor says we start for trenches in a few days. China of 2 nd expedition arrived today.

July 17, 1898 : Answered some letters. Guess I will write to usual all the girls I know as I find home letters are very fine things to receive. The company is getting to drill

5 C. U. Gantenbein, p. 348. Lee K. Morse, Co. L, 27, no occupation listed, 1st Sergeant. His accidental death will be discussed on March 25, 1899 listing in diary entry. 
more like old Co. H. It makes me feel better. There is not much variety in garrison life and not much to write about.

July 18, 1898 : Wrote to Emily, Mary, Helen, \& Marion just answered Lotties [Lottie's] letter told her nothing. I wonder what Mary, Helen, \& Emily will think about a letter from me. 6 weeks ago if I were going to write I would have laughed. I found I need the home folks more than I thought for. Also wrote to mother.

July 19, 1898 : Am sick of guard. Nothing to write of. Wrote to L [Lottie].

July 20, 1898 : Slept in afternoon. Rumor says we start for the trenches tomorrow. California boys were fired on. No one hurt. 14 went crazy from heat [and] had water, and [went crazy from] the nervous strain of being in trenches and being fired at without retuming fire.

July 21, 1898 : Did police duty nearly all forenoon. Wrote letters in afternoon. We will not leave for before Manila until after Menitt [Major Gen. Wesley Merritt] arrives unless something develops that makes it necessary. Dewey says he has no authority to firing government. Anderson wants to move. We are also waiting to hear about outcome of peace negotiations.

July 22, 1898 : Nothing happened.

July 23 and 24, 1898 : Rain both days. 
July 25, 1898 : Lee Mirre [,] 3 other Co. L boys [,] and myself rowed Col.

Summers across the bay to where troops are camped. ${ }^{6}$ We ran line and went as insurgent firing [on] line. Where [Then] there was a half hour wait. I'll not go again till I leave [have] too.

July 26, 1898 : Rained all day. No drill.

July 27, 1898 : One drill. Received rubbers [and] fine hat.

July 28-29, 1898 : Nothing happened regular drill.

July 30, 1898 : Signed payrole will probably get money Just [first] of next week. We are to be paid from the 2nd of May the day we were called out instead of the 13th the day we were mustered in.

July 31, 1898 : Made two trips in boat once to the point once to Steain [on the ship] Kwong Hoi [Kwonghoi]. ${ }^{7}$ Very stormy all day. Jaeirs said we were in tail end of typhoon. Five transports of third expedition came in today [they are :] Cavite[,] Mug on City[,] Valencia City[,] r Peira ohri[,] \& Indian 8 -- we will get mail tomorrow. We got a few Oregonians.

6 C. U. Gantenbein, p. 44. The camp was Camp Dewey located across the neck of the bay from Cavite to Paranaque. The Oregon boys hoped to follow soon.

7 There is no place on any atlas that was researched by this author that Stean existed as a city on the Philippines. The "point" is most likely about 60 miles south of Cavite near Batangas, most quickly accessible by boat.

8 C. U. Gantenbein, p. 2. The Third Expedition was made up of four companies of the Eighteenth and four companies of the Twenty-third U.S. Infantry, four batteries of the Third U.S. Artillery, and one company U.S. Engineers, First Idaho Volunteer Infantry, First Wyoming Volunteer Infantry, Thirteenth 
Aug. 1, 1898 : Do police work in quarters with Freeman. Lamberson ${ }^{9}$ \& Holbrook were not reporting at retreat. Sargent (sic) Clag [Clagett] reported himself and Barrett. I'd not crow why he'd did not report us. Received three letters from home 2 from folks $\& 4$ from Luther with his picture.

Aug. 2, 1898 : Expect Monterey \& Monoduaon [ships are due] any day now. Heath expedition due in about a week. Not yet paid probably will be the last of week. Our lines near Manila have moved up between the Insurgents \& Spaniards. Insurgents have left that side of city. At night working party was attacked by Spaniards in force. The battery and Penns sought [of Penns had fought] finer Penns firing \& 7 out of 50 of their shots [hit their target] before Calif came up. Calif fought well and Spaniards were forced to retire. 312 Spaniards were killed and probably 1000 were wounded. 8 Americans were killed \& 40 wounded divided among battle of Penn. and Calif. No one could have fought and stood better than the volunteers showing against much odds. [Their actions were] was fine.

Aug.3, 1898 : Everyone has left Cavite except one battery and Wagon vets. It is very probable we will stay here as guard. Everyone is hot about it but seems to be no help although Gen. Anderson says that we will get our share of fun. It is possible only one battalion will be left in that case I am afraid it will be the 2 nd (mine). Hope not.

Aug. 4, 1898 : Corp. of Guard. Big scare in the evening. At 10:00 we received word that an attack was to be made on us by natives of Cavite. All three chiefs were called out and posted 20 pickets. Co. A. furnished 30 men as extra guards \& the remainder of Co. held itself in readiness. Battle was prepared and carried on streets. The excitement

Minnesota Volunteer Infantry, First North Dakota Volunteer Infantry, Astor Battery, and Detachments Hospital and Signal Corps.

${ }^{9}$ C. U. Gantenbein, p. 275 . R. A. Lamberson, Co. H, 21, Clerk, Private. 
was all caused by this wedding among natives. Did not have a bit of rest for 24 hours [I] was in duty and running all the time. Monterey came in today--no mail on her.

Aug. 5, 1898 : Laid around and slept all day except evening drill.

Aug. 6, 1898 : Did not do police duty. Had a crew of 10 oarsmen to row Gen. Anderson but we did not go. Raining hard nearly all day.

Aug. 7, 1898 : Mail leaves today. Sent letter home \& to mother.

Aug. 8, 1898 : We were paid today up to July 1 st. I received $\$ 35.40$ after paying debts [and] deposited $\$ 25$ with paymaster until discharge. Draws $4 \%$. Have $\$ 5$ to run me until next payday. Which we expect sent [on September] 1st. Money deposited with paymaster cannot be withdrawn until discharge. We understand our pay will be doubled from July 1st.

Aug. 9, 1898 : Foreigners are leaving Manilla. Dewey gave notice that all must be out by Aug. 10 at 10: 30. We expect to [do a] bombardment tomorrow.

Aug. 10, 1898 : No bombardment today [I] understand another 24 hours has been given for the arrival of sick and women $\&$ children. We move from old quarters today down into fort. We have about same amount of room but end of building is fun and not much roof over any of it so when it rains everything is damp and boys at lower end might as it well be out of doors. Other boys have much better quarters.

Aug. 10, 1898 : No bombardment yet do not know why seems as if every thing was ready but supportment knows best. This is rainy season and the rain comes down in torrents about $2 / 3$ of the time. Oregon is not in it. Mail leaves tomorrow. Wrote to 
mother, Miss Reid \& Mr. \& Mrs. James. Also sent home book of Mrs. Hogins and old letters and pictures.

Aug. 11, 1898 : Raining like h - - everything disagreeable. The boys nerves in the trenches must be in a horrible state. Fourth expedition expected at any time. Also Monadiwick. Dispatch boat from Hong Kong is also drier. Will probably bring news of truce negotiations.

Aug. 12, 1898 : Rain again. We received word today that we were to take Manilla (sic) the 13 . We the $1 \& 2$ bombardment and Co. F of the 3 rd to be used as a landing party after the bombardment by the troops. Cap. told us to make a good showing at evening drill \& possibly we might be appointed to Gen. Merritt's body guard but Co. F. would probably get it because we were Col. company. We all spruced up \& shaved I faced my beard with the others and we put up a splendid drill that F Co. could not touch but it was no use [,] F Co. had the pull. We were issued 10 extra rounds of ammunition and took rations for two days. We stored everything but Haversacks and Ponchos. Many of the officers and boys celebrate the good news by drinking too much.

Aug. 13, 1898 : Up at 4 breakfast at 4:15 and aboard the Kwonghoi at 7 . When we went out to fleet at about 9:15 fleet move towards Manilla (sic) and bombardment commenced at 10 A.M. ${ }^{10}$ It was a pretty sight but we could not see well enough to tell effect of shot. Qfficers could see our land troops advancing. Shortly afternoon the town surrendered. 11

10 C. U. Gantenbein, p. 46 . The first shot was fired at $9: 15$ A. M. by the Olympia it was a six inch gun off her starboard side.

11 C. U. Gantenbein, p. 47. The Spanish General agreed to surrender, and asked to have 600 men put inside the walled city of Manila to maintain order. The 600 men were made up of the nine companies of the Oregon regiment and the two ships, Kwonghoi and Zafira, took the men in but the Kwonghoi ran 
After a long wait we started for the city. When about 200 guards [yards] from pier, boat grounded and we had to go ashore in small boats. We landed just in time to see Old glory run up. Marching about the walls of the old fort we stopped near the flag and gave three cheers. Then proceeded through fort to castle. Here we lined up by companies and Spanish forces marched in front of us and surrendered. We then marched into palace and were quartered in the stables for the night. However it was not the first and probably will not be the last times we have to sleep on the rough stones. I secured from the palace a pretty little vase as a momento. The palace is an immense square building of stone two stories high. The interior of main rooms is beautifully fixed up. About the only feature that had modern appearance was the electrical lights. There was a general air of ancient grandeur gone to decay. There is also the case of the whole town which is very ancient.

The walls and Fort being typical of past ages with its old viru called walls, moats, porticullis etc. The old city could never be captured by land attack. In places the walls are 100 feet thick and the moat 200 feet wide.

It was a long to be remembered sight the raising of the flag and the surrender of the soldiers. Most of the privates seemed glad but the officers especially the younger ones were broken up, the women were also weeping and no one could not help feel sorry for them. Our boys are as usual all swelled up, were being given the post of honor. The landing party was a dangerous bit of work for there were only two batteries of us marching through a city where there were at least 5000 Spanish soldiers armed. 12

aground trying to reach the sea-wall and her troops had to be transported in launches. Company $F$ were the first troops to land.

12 C. U. Gantenbein, pp. 47-8. There were five companies that marched through the throng of soldiers that did number close to 5000 men they had their bright splendid uniforms of Spanish officers and soldiers and Oregonians could not help but remember the tales of Spanish treachery. 
Aug. 14, $1898:$ Up at the usual hour. After breakfast, started for barrack where we are too be quartered. They are very fine modern barracks but on account of water being shut off they were in a most fearful dirty condition. The Spanish women stared at us when we marched by and judging by their looks bore us more innity [emnity] than the soldiers. After reaching quarters we went downtown in body to the municipal headquarters and got bunks.

While waiting two Spanish women presented some of us with cigars. We answered with a most elaborate bow. Once in a while are seen a Spanish woman that is very handsome but they seem to decay early. After returning with bunks I was unfortunate enough to be detailed guard duty at palace. We relieved Co. F. Our duty was to disarm troops as they surrendered. In the entrance to palace were immense piles of swords belts guns and ammunition. That night a body of about 4500 soldiers marched by to their bugles and surrendered. It was a pitiful sight. They were dirty and forlorn and realized their position. Slept on marble floor in entrance [I] can sleep anywhere now and get rest.

Aug. 15, 1898 : We off duty. Fired up bunk and slept. Freeman, Watson, Morrow \& I are together. Took walk over to Wyoming's headquarters. Just outside of walls for Capt. Wells \& McDonald for some wine. Came back and slept. Our two day provisions are gone and Gantenbein is so inefficient that he has secured nothing. 13

13 C. U. Gantenbein, pp. 48-49. For two days the commands from the trenches came in to surrender thus Americans were kept quite busy receiving and storing the arms and ammunition. Colonel Summers was placed in charge of everything inside the walls as the provost marshall leaving the immediate command of the troops to Major Gantenbein. The duties were so heavy that not many soldiers were able to sleep. The Oregon regiment was given charge of the southern half of the city along with Co. F. 


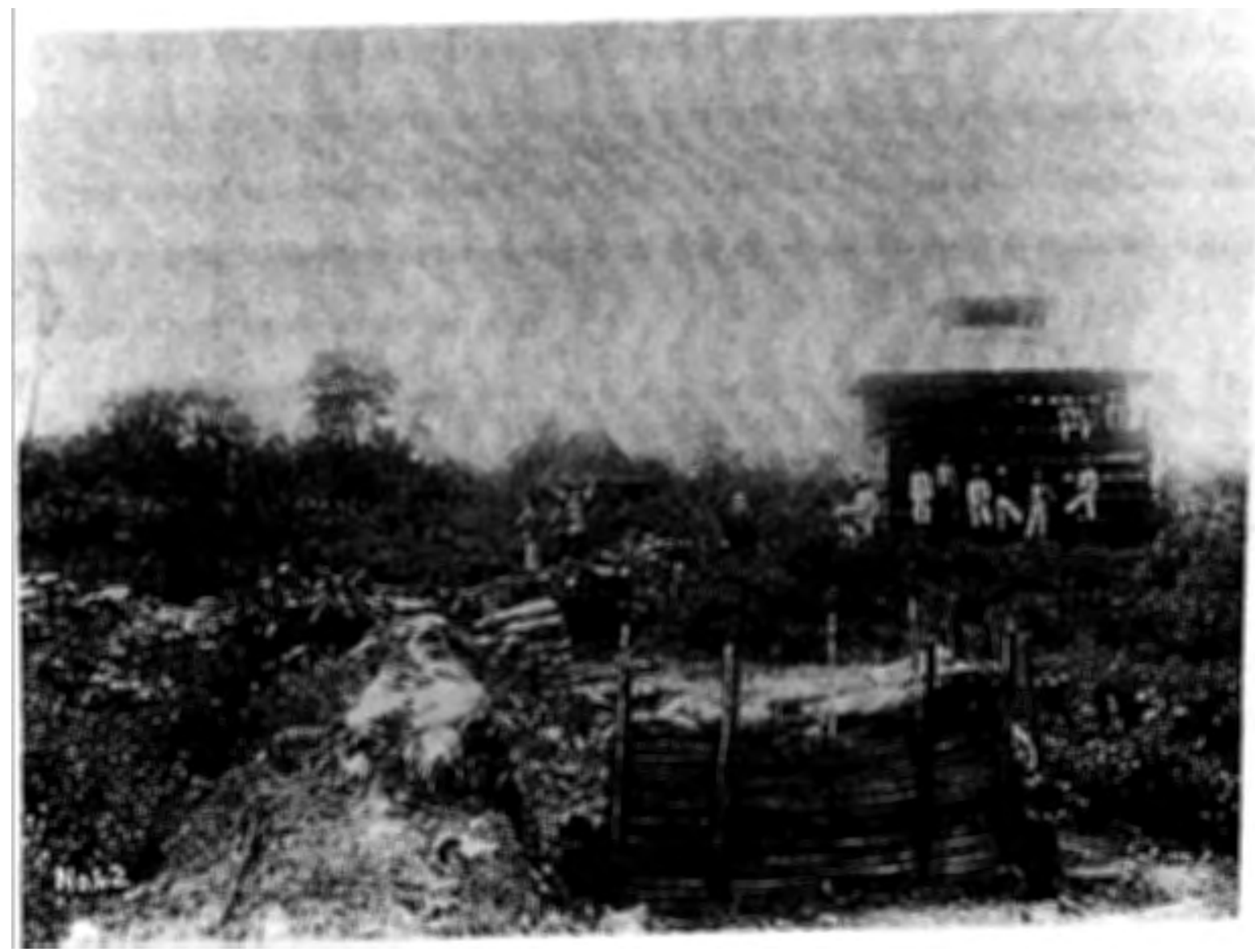

Figure 4. Blockhouse 14 Outside of Manila. Oregon Historical Society Negative Number - 86864 Lot 254, Box 1, f. 7 . 


\section{CHAPTER VI}

\section{AUGUST 16, 1898 TO JANUARY 4, 1899 : GARRISON DUTY BEFORE THE OUTBREAK OF FIGHTING}

From the middle of August to the beginning of January, a long monotonous period of the same duty every day, and little to no diversionary activity occurred for the Oregon Volunteers. Bell did his duty from an old Roman Catholic church called Saint Augustine. He received and wrote letters, listened to many rumors about home going, and did a lot of laying around and resting. Most of his entries reflect his feelings about being there and doing nothing. Very few of the passages are over four lines long and at times he clumps his periods of boredom into one entry.

There were four things possible at this period of time for the Philippines. The Philippines could be given their independence; Spain could keep them; Germany could obtain them; and the United States could take possession of them. The United States saw a window of opportunity for an Asian market and did not want to give up such a potential economic money market in the gateway to China's trade.

McKinley did not place limits on American involvement. In mid - July he had spoken of acquiring Manila and Luzon, and by the middle of September he demanded both Manila and Luzon from the Spanish. McKinley instructed his peace commissioners to acquire all the islands. On December 10, The Treaty Of Paris was signed. This treaty transferred the sovereignty of the islands to the United States. The United States paid Spain 20 million dollars for the islands. McKinley wanted the United States to protect and 
not abuse the Filipinos. He wanted the mission of the United States to be one of benevolent assimilation.

The Americans intended to rule the Philippines until the Filipinos could effectively control the islands. The United States intended to help the Filipinos when they were ready to take control. There were no guidelines or criteria set to show when the Filipinos would have been ready to govern on their own. Unfortunately, actions carried out by Army soldiers resembled oppression in some cases. Efforts by the Army to clean up Manila streets, enforce sanitary regulations, or collect taxes were carried out in an authoritarian manner that showed little concern or respect for Filipino and customs. The Filipino people thought of U. S. control as another form of oppressive rule and worried that they had traded one oppressor for another. The Filipino leader, Emilio Aguinaldo was ready to lead his people against American rule and establish the Philippines for the Filipinos.

\section{The Diary:}

Aug. 16, $1898^{1}$ : On outpost at Gate next to main entrance. Lots of travel. Have to examine passes and disarm. Secured several revolvers one of which I keep. Yesterday there were many swords taken away. I took a machete as a souvenir. During day arrested 4 or 5 insurgents. Clothes are getting very dirty hope packs will soon be brought from Cavite. In morning of 17 th went over to the town and got breakfast. Just outside the gate where I was is a monument to Magellan and it is supposed to be over his bones.

Aug. 17, $1898:$ Off duty, rested up. Have rest [and] considerable sleep.

${ }^{1}$ C.U. Gantenbein, p. 3. General Merritt received a telegram that day from McKinley announcing the cessation of hostilities. 
Aug. 18, 1898 : Out post at treasury building where there is considerable Spanish money. Hard post cannot leave it at all. Nothing of importance happened. ${ }^{2}$ For rations for the 24 hours, 21 of us were issued 2 cans of beef, nothing more.

Aug.19, 1898 : Off duty. Packs came. Fixed up bunk Oregon boys allowed no passes so have had no opportunity to see town. Went out for water and went through an old Catholic cathedral. ${ }^{3}$ Very large. Old pictures. Full of stores for soldiers as were also other churches. Spanish soldiers were quartered there. Bought of a Spanish soldier for $\$ 4$ Spanish [money] a medal for valor and two awards of merit. Good buy.

Aug. 20, 1898 : Carr Morrow has been quite sick but is better though. Laid (sic) around barracks all afternoon studying law. At one o'clock I got myself Freeman, Morrow and O'Neill [Neil] a pass good for walled town for Oregon boys are not allowed outside of it. However we passed out the gate by passing off as $\mathrm{N}$. Dakota boys. At main gate we were turned back but made it at second gate. We did not have time to take in anything but main street of town. Appearances there is but one. The town is a strange mixture of grandeur \& modern speed. I made a hasty inspection of stores for relics and located some. Rest of boys went to beer hall \& got gay. We passed back into lines safely. Nearly all our boys who had passes were drunk. It was the first liberty we had for a month.

${ }^{2}$ C. U. Gantenbein, p. 49. Between August 15 and January 4, five long weary months passed for the Oregon men. The months were filled with issues,trying experiences, and disappointments. Directives had been issued,by the McKinley administration regarding the future of the Philippines. The U.S. was to rout the Spanish, establish order, enforce U.S. sovereignty (even though the Philippines were not in the possession of the United States) and have the U.S. there only to protect, not fight Filipinos. The soldiers were soon reported to be weary of their service in the tropics, but there was no alternative for the U.S. government. The soldiers never knew whether their sacrifices were for American possessions, or a continuation of an adventure. They also believed that through their contract of enlistment there would soon be a discharge after the cessation of hostilities.

3 This was Saint Augustine's Roman Catholic Church. 
Nearly had a bad fire in quarters. A Company B man carrying a monkey passed a large lamp. Mr. Monkey makes a jump, tips over lamp and soon burning oil is spreading. Man with monkey has clothes on fire and jumps into a bed \& covers up [and] is unhurt. Fire is just out, without damage. New town of Manilla (sic) is on me [my] side of passage. Old or walled town in other new town is of Spanish pattern. Our street line [has] no modern improvements. Before siege was raised eggs were worth 40 cents a piece, flour and coffee unattainable for cils. Military stores were stored in Catholic churches in immense quantities. They would not have lasted for a very long time.

Aug.21, 1898 : On guard today. Have a detail of 3 men in a large cathedral filled with stores. Rice, coffee, sardines, oil, sugar, salt, dried fish etc. Spanish soldiers to the number of a thousand or more quartered here if they wished it as a fine time for them to murder us but all the privates seem to be decent fellows and treat us fine and are more than glad of having prisoners not fighting insurgents whom they despise. I do not blame them, for a dirtier, lower, more disgusting lot of fellows I cannot conceive. All rations [for] six Co. $\mathrm{H}$ men were issued for 24 hours was 4 cans meat. Letters from home arrived today. How did we yell when we got om [them]. Freeman \& I went out to Spanish restaurant and got supper $\$ 3.00$. Menu [was] Scrip \& olives, chickens in tomatoes, fish salad, beef steak $\&$ french fried potatoes, bread, jelly, bananas, black coffee $\&$ cheese. Wine if desired.

The church where we are is very fine and large one It must be at least 400 [feet] by 400 [feet] and the alters, crucifixes, trappings, paintings etc. are magnificent. The paintings are oil and bear every man of great age. They are dim, the canvas is cracking and rolling away and (in my junior) They bear the other great mark of age [and that is] lines poor. 
Aug. $22,1898^{4}$ : Lay around all day except started a letter for home.

Aug. 23, 1898 : Still writing letter. Drill show at 8:30 and then go to bay for a bath. In afternoon went on detail for commissary to new Manila. Took supper in town with Dillon [at] 8:50 then took drive around Luinilla [Lunetta].

Aug. 24, 1898 : After drill this A.M. got pass for Freeman, Morrow, Watson \& myself. From 11 to 6 . We took in whole town and saw all there was of interest. Took dinner at English restaurant and bought a few souvenirs in all the 4 of us spent between 50 \& 55 dollars and had a fine time. Mail came last evening got nothing but a paper. Nothing particular happened today.

Aug. 25, 1898 : Got letter from Mame today. Sent home 2 packages of curious etc. slept from 1 to 5:30 P.M.

Aug. 26, 1898 : Lay around barrack all day. Took soap bath after drill.

Aug. $27 \& 28,1898^{5}$ : Nothing of interest. Same old story of barrack work on 28 th was guard at St. Augustine Church.

Aug. 29, 1898 : Rested \& slept all day, usual thing after guard.

4 C. U. Gantenbein, p. 3. The disembarkation occurred of Light Battery D,Sixth U.S. Artillery. The desire to get back to the U.S. was aggravated by the act of favoritism done by the War Department in returning this Battery so shortly after the Spanish war ceased.

${ }^{5}$ C. U. Gantenbein, p. 5. On the 28th General Merritt assumed duties as military governor and transfers command of Eighth Army Corps to Major Gen. E.S. Otis, U.S.V. Brig. Gen. Arthur McArthur relieved General Anderson in command of Second Division. 
Aug. $30,1898^{6}$ : Gen. Merritt left for Paris and Dewey for home. England has allowed our ships, also Spanish if there are any, to be docked at Hong Kong.

Aug. 31, 1898 : Mush this A. M. Will probably get money Saturday the 3rd. All kinds of rumors afloat as to time of our return home.

Sept. 1, $1898:$ On guard near palace in large building alarmed by private prison U.S. wants it for barracks. There are 6 or eight Spanish families there with whom I became more or less acquainted. There was a number of young folks from babies up. Had a pleasant time especially with the little girls and boys.

Sept. 2, 1898 : Rested in forenoon \& in afternoon went over town chased around a while then went into a saloon where we met 4 English sailors. We sat and talked until time to return to quarters. 2 white suits and a helmet were issued to us today.

Sept. 3, 1898 : Nothing happened today. In evening we had dress parade out on the Lunitta (sic). Boys made a fine appearance in their white helmets \& suits. We did not get back to camp until about 7:30 making supper very late.

Sept. 4, 1898 : Nothing of note today. Here after we will drill at 6:45 A. M. instead of 8:30. Dress Parade Tuesday, Thursdays, \& Saturdays. Company Monday, Wednesday, and Friday.

Sept. 5, 1898 : On guard at Palace. Nothing happened out of ordinary.

${ }^{6}$ Ibid. Gen. Otis relieved Gen. Merritt in command of the department of the Pacific and as military governor of the Philippine Islands. 
Sept. 6, 1898 : Rested all day.

Sept. 7, 1898 : Lay around barracks all day listening to all sorts of rumors as to pay day and home going.

Sept. $8,1898^{7}$ : Got carriage and Lee Morse \& I went for a ride. Went several miles beyond city toward Malalin [Malolos]. Insurgents still keep sentries their first line within 100 yards of ours.

Sept. 9, 1898 : Mail came this evening received several letters and a letter from mame.

Sept. 10, 1898 : Lay around and read all day. Co.H. played baseball with Co.E. Game stopped by rain but $\mathrm{E}$ Co. was leading.

Sept. 11, 1898 : On guard First Sunday since I enlisted that my turn came on Sunday. Two of my men took sick and had a little trouble with 2 drunks. Some of the boys from the Pigmy, an English ship, came to see us. Will try and return the visit this week.

Sept. 12, 1898 : Freeman took sick today. Seems to have Malaria. Mail was expected but did not show up.

Sept. $13,1898^{8}$ : On guard St. Augustine church. Nothing special happened.

${ }^{7}$ Ibid. General Otis demanded the withdrawal of insurgent forces from the entire city of Manila,its suburbs and defenses.

${ }^{8}$ Ibid. General Otis conferred with an a commission appointed by Aguinaldo in regard to his demand of Sept. 8. 
Sept. 14, 1898 : Took walk and slept all day.

Sept. $15,1898^{9}$ : Pay day. Went over to Manila, got something to eat. Bought box of cigars to send Bud \& Hogue.

Sept. 16, 1898 : Nothing happened.

Sept. 17, 1898 : On guard at St. Augustine. Capt. Gadsbey (sic) officer of day tapped in where sentry was making rounds, took guns then raised a stink. I was asleep. That was O.K. but took belt off which was wrong. Gadsby reported me.

Sept. 18, 1898 : Guard took wads. Corp. Bell under arrest for neglect of duty. Released. I think this will be the last of it I think. Gadsby is afraid to press matters. Maybe mistaken.

Sept. 19, 1898 : Nothing further about neglect of duty.

Sept. 20, 1898 : Dobie, Dodge, \& Smith go to hospital. Ganties discharge papers seem to be hung up. Cant be proud. He may not go in Rio Janerio.

Sept. 21, 1898 : Went over to new Manila with Morse \& Hubbard and had a good dinner and took in Chinatown and Photograph galleries. Had a huce of tumeron. Got $1 / 2$ clay odd cups for Mame.

9 Ibid. Insurgents withdrew from limits of city of Manila, as established by Otis, with exception of districts South of the Pasig river. 
Sept. 22, 1898 : On guard at San Francisco church. Nothing unusual.

Sept. 23, 1898 : Off guard. Rested.

Sept. 24, 1898 : Inspection and guard [gun] cleaning, went cross river.

Sept. 25, 1898 : Sunday went to church.

Sept. 26, 1898 : Mailed letters to Mother and Lil. Also sent some chinaware to mame.

Sept. 27, 1898 : Two of our men died yesterday. ${ }^{10}$ Buried today. We get mail today sometime.

Sept. 28, 1898 : On Guard [at] Ricollidos church. Mail came. For me is [are] letters. Read 2 Luther, 1 Lottie, 1 Mary S., 1-10 mamma, I received some papers but saw nothing of packages mentioned. I also got some papers and paper.

Sept. 29,1898 : Rested all day. Wrote to R \& H. In evening got pass. Took a sea boat slung by sting arci crossed over into new Manila. Got 2 ice creams and candy. Walked through main street then back.

Sept. 30, 1898 :PHard drill this morning between 1 Qerri gun of $\mathrm{H}$ and an A Co. man for orderly. A man got it. Wrote to home. Freeman went to hospital.

${ }^{10}$ C. U. Gantenbein, p. 677 . The two men were George W. Starmer of B Co. and Eliot W. Ordway of $\mathrm{H} \mathrm{Co.}$ 
Oct. 1, 1898 : Watson sick today. Regular Saturday inspection and dress guard.

Oct. 2, 1898 : Sunday wrote to Lottie \& Mr. Sellwood. Two more of our men died. ${ }^{11}$

Oct. 3, 1898 : Lay around barracks all day, same old story of barrack duty.

Oct. 4, 1898 : Watson getting better I think. Have not received packages mentioned in letters. All kinds of rumors as to going home time.

Oct. 5, 1898 : Carr Morrow on guard again for the first time in several weeks.

Oct. 6, 1898 : Birthday. On guard at the collecties. I hope will not have to spend many more holidays on guard. Received news of Oxdways [Ordway's] death.

Oct. 7, 1898 : Rested most of forenoon In afternoon mosied down to other end of building. Another company coming in here. A little case of small pox in camp, no scare yet, hope it will not be epidemic.

Oct. 8, 1898 : Company sent letter of condolence to Mrs. Ordway. Went over town with Lee. Went through chinatown.

Oct. 9, $1898^{12}$ : Sunday. Went to church.

11 Ibid. The two men were Ormand Fletcher and James J. Reid, both of M company. 12 C. U. Gantenbein, p. 4. While traveling up the Pasig river in a steam launch, General Anderson and his staff are ordered to the city by a Filipino guard. 
Oct. $10,1898^{13}$ : Played out with Lee in morning went over town and took in Philippine Circus saw some very fine tumbling

Oct. 11, 1898 : On guard at St. Augustine. Bad night. Had diarrhea. Priest wants me to come each day \& teach him English. In morning arrested a couple boys whom Forrest charged with stealing watches from them.

Oct. 12, 1898 : Slept all day Carr gets detailed as orderly on some commission. The court commission I think.

Oct. 13, 1898 : Came off guard I have skipped a day. I should have gone on guard on the 12th instead of 11 th. Guess nothing Happened on 11 th [or] I would have remembered.

Oct. 14, 1898 : Sick with cramps and diarrhea all day. Rumors about going home are still thick but it seems to me we are booked until spring time any way.

Oct. 15, 1898 : Considerably better today. Lee Morse is out [in a fight] knocked out. Raining hard. Coolest weather we have yet had.

Oct. 16, 1898 : Played crib with Lee today both of us are better.

Oct. 17, 1898 : Lay around barracks all day.

Oct. 18, 1898 : On guard in quarters first time since being in Manila. Like it about same as outpost.

13 Ibid. Gen.Otis made a formal demand for the retirement of Filipino forces of Paco and Pandacan to outside the city limits. 
Oct. 19, 1898 : Nothing happening. Have diarrhea again.

Oct.20, 1898 : Chas Ruhl died today. He was sick but a few days, lasted with a boil turned to erysiphilis caused meningitis. He also had typhoid malaria.

Oct. 21, 1898 : Ruhl buried today. Wanted to embalm and send him home but it was not practicable. He was buried in Manila vaults. Had charge of firing party consisting of Taltz [Teatz], Percy, Dustin, M. Holbrook, S. Holbrook, A.P. Watson, Jarmon (sic), and Pratt.

Oct. 22, 1898 : Another small pox patient taken away today. I was vaccinated again Oregon boys were to play baseball with Idaho today but rain prevented.

Oct. 23, 1898 : Sunday. In bed all day with cramps and diarrhea. In evening went to $L$ Co. quarters played Lie [Lee] Crib was badly beaten.

Oct. 24, 1898 : On guard at Recollecties. Nothing of note happened. Saw the arrest of a Lieut. of Aguinaldo's who was telling Spanish soldiers that we were to fight in a day or two and he wanted them to help.

Oct. $25,1898^{14}$ : Oregon's played Idaho's baseball yesterday score 17 to 2 favor Oregon. Raining like h - , - today.

Oct. 26 to 28, 1898 : Lay around barracks doing nothing. On 27 Frank came from hospital and on 28 Dutrie came back. Both better but not yet O.K. for duty.

14 Ibid. Filipino forces retired from points indicated by Otis in his Oct. 10 demand. 
Oct. 29, 1898 : On guard. In evening Dins Rea took my place for a while and I went to reception given by women of Red Cross. Had a pleasant time. Oregon boys beat S. Dakota at baseball score 5-0.

Oct. 30, 1898 : Rested all day.

Oct. 31, 1898 : Did very little police duty. Mush in morning. Rumors that we will soon be sent home.

Nov. 1, 1898 : Halloween last night. Battalion (sic) have extra duty for raising cane.

Nov. 2, 1898 : Carr Morrow sick. Will take his place as orderly tomorrow.

Nov. 3, 1898 : Carr went to hospital. I went to court. Lieut. Hildarich M. Dax Judge advocate. Good place. Am reading International Day by Glenn Honbook [Hombrook] series.

Nov. 4, 1898 : Read nearly all day.

Nov. 5, 1898 : Pay day. Several more cases of small pox from our regiment.

Nov. 6, 1898 : Last night I called in Ladies of Red Cross. Ate dinner with me.

Nov. 7, 1898 : In evening went over to Manila [and] bought underclothing, handkerchiefs, envelopes, \& cane. During day ran guard man errands for Lieut. Holdrets 
[Hartman]. Freeman \& Harder will probably go places I mentioned to them. Try rape case today. 15

Nov. 8, 1898 : Rape case finished. Verdict not given. Lost $\$ 5$ gold.

Nov. 9, 1898 : Getting ready for editors case \& getting commission together. Frank F.[Freeman] gets place with commutation of rations. Expect mail in day or two.

Nov. 10, 1898 : Mail arrived today. Received 9 letters \& 2 papers from home and one from Lila. Thought I would receive more. News from home looks as if we should be here some time, maybe our full term. Last night bought 4 canes $\&$ one pencil madiser bullet.

Nov. 11, 1898 : Did nothing all day. Maybe letters to Mamma, R \& H., Luther \& Lila.

Nov. 12,1898 : Heavy rain all day \& night. Sean dig leaves today with sick for home. Rained hard all day. Was so stormy. Sean did could not sail. Went to Billy bid prison or could work in court.

Nov. 13, 1898 : Still stormy. Played crib with Lee and in evening went across river to New Manila \& took dinner. Freeman has requested job with commutation of rations so see little of him now. 
Nov. 14, 1898 : Mail arrived today received several letters. One from Lottie. Fairly started on sedition case. It will be interesting. New recruits are in the bay will come in tomorrow. Received new beds. Hot or good as cane made of bamboo.

Nov. 15, 1898 : Busy all day with sedition case. It is an interesting trial. Last evening woke up with a gagging feeling throat finally threw up a worm about 6 or 7 inches long. Looked like an angle worm.

Nov. 16, 1898 : Went to Dr. this morning about worm. He says if there are any more there [they] will probably have to throw em [thrown] up. Went across river with Lee took lunch at Alhambra. Got some fine boston (sic) brown bread at Claggetts stand.

Nov. 17, 1898 : Feel fine this A. M. Hope to finish sedition case today. Were rumors about home going. It is possible we may be exchange.

Nov. 18,1898 : Rape case finished yesterday. Expect mail today.

Nov. 19, 1898 : Mail did not come. Busy big part of day getting ready for embezzlement case. In evening our officers gave banquet to California officers. There has been more or less hard feeling between the two organizations which it was hoped to overcome.

Nov. 20, 1898 : Sunday Lay around barracks most of the day. In evening took walk along Luenetta (sic) down to river, crossed in canoe went to Oriental restaurant for supper. An unusual thing for me drank [to drink] fine wine with dinner.

Nov. 21, 1898 : Try sedition case tomorrow. Nothing of importance happened. 
Nov. 22, 1898 : Started sedition case. Good many spectators among them was American girl said to be a newspaper correspondent. Mail came today. Received 3 letters from Mamie [and] Sty sent me a camera [It is] something I have wanted for a long time, if the films work will have a fine time with it. Our rookies also came. ${ }^{16}$ Have not landed yet. This mail brought me a nice box of candy from the Miss. Bodleys.

Nov. 23, 1898 : Busy with sedition case all day. Rookies will land tomorrow.

Nov. 24, 1898 : Thanksgiving. Rookies came up this A.M. Rumors some. They seem like an fine set of boys. In evening [had] banquet over in a American restaurant. We had fine time. Some good toasts by Capt. Mc [Macrum] both Lieuts. Morrow, Freeman, Watson, Brook, Claggett, \& Bill Smith and Patterson. Morrows on the girl I left behind was particularly fine. The meal was fine but they left out several courses.

Nov. 25, 1898 : Off special duty. Morrow goes back this A.M. Lay around and slept all day.

Nov. 26, 1898 : Took a few pictures. In evening played crib and went with Lee for ice cream.

Nov. 29, 1898 : Sunday. Kerrigan on Saturday arrested for refusing to work in kitchen police.

Nov. 30, 1898 : Drill \& school resumed slept all day. Wrote short letter to mother.

${ }^{16}$ C. U. Gantenbein, p. 8. Those "rookies" were the Twenty third U.S. Infantry and Washington Volunteer Infantry. 
Dec. 1, 1898 : Read mail [Received] one letter from Bess W. \& one from Camilie one also from Mamie \& Mother. Answered all of them. We hear Co. $\mathrm{H}$ is to be detached for duty at custom house.

Dec. 2, 1898 : On guard today. First time for several weeks and probably the last for it is certain that we will be detailed at custom house. Another mail leaves this evening so will write a letter to mother if possible.

Dec. 3, 1898 : Wrote two letters. Slept nearly all day.

Dec. 4, 1898 : Rained on camera. Harpers Weekly correspondent who is going to interior will get pictures. I did fatigue work. Read \& played crib in afternoon \& evening.

Dec. 5, 1898 : Lay around quarters all day. Sick at stomach and very dizzy. Threatened with Malaria.

Dec. 6, 1898 : Already to move this A.M. Moved to custom house this P. M. Quarters are very crowded and premises are dirty but think duty will be better than drilling.

Dec. 7, 1898 : Spent all day getting men to clean up quarters and yard. Mail came, got letter from Home, Dolly, Pratt, Frank, Grant, Annie Reid also picture from Annie.

Dec. 8, 1898 : Moved officers goods to new quarters. My duty will be to as Corporal of the Guard every 3 days. Most of the boys are on ship board.

Dec. 9, 1898 : Mailed letters to Grant and Mother. No guard duty. No men. I only have charge of quarters now every 3 days. All boys seem satisfied with work. 
Dec. 9-13, 1898 : Have been working to get settled in quarters. Every thing is now running smoothly. I have changed quarter all the time. But little to do. Other corporals out on boats. Every one seems satisfied. Christmas boxes coming ashore and we should get them in a few days. Camia not yet back. Every one seems confident that we will be home within 3 or months. Fred Mollner [Noltner] the 1st Sgt. has received a furlough with permission to leave Island. He will probably go home $\&$ receive a discharge. ${ }^{17}$

Dec. 14,1898 : Boxes came yesterday two for me so far. In each 2 jars were spoiled on account of heat. One was from Mrs. West other from Mother \& Neighbors. Will send letters to all this or next mail. The box was one of best sent and will last some time.

Dec. 15, 1898 : Wrote to Mother, Mrs \& M.West, Miss Reid, Dolly Pialo \& Candie. Astors Batten about home Today. The American has a telegram stating regulars are on way to relieve us \& we hope to be out in Feb. or March.

Dec. 16, 1898 : Nothing of note occurred. Launacia's Mother \& sister called [and] seem to be of better \& brighter type than most Philippines. Will call on them Sunday.

Dec. $17,1898:$ Have at last managed to get scavengers to clean up each moming.

Dec. 18, 1898 : Sunday. Had a very fine dinner. Christmas boxes add greatly to our bill of fare. In afternoon Jim, Carr \& I called on Launacia's folks. They live about 2 miles from Adeiano in a pretty lougi district. Besclis mother father there is Herbina about Launacia are very bright and pretty. They are like all Phillipines (sic) but cleaner $\&$ are

17 He does not leave. On the 10th the Treaty of Peace was signed between U.S. and Spain. 
brighter. Carmen does fancy work for soldiers. Mother makes chocolate. They are very hospitable. Girls are odd. Do not hesitate to brush hair, powder face before company. It was a funny call we could not speak Togae or Spanish \& they no English. Some of our rude remarks were startling. They served chocolate snails. Old man was sick. Palpitation of heart. Insisted on our staying. Are going next week to take picture.

Dec. 19 to $24, .1898^{18}$ : Neglected to write each day so will lump it. Nothing of importance has happened except the arrival of mail and more wies [wires]. I received another box. Letters from home, Marian, [and] Lottie. Wrote to Bert Harrell and others sending boxes. Mr. \& Mrs. Miller, \& Mrs. Dallin sent a cake. Astor Battery has gone home. American says 6 regular regiments to regulate us. If this is so we ought to be home in 3 months. Jim Watson went to hospital with fever.

Dec. 25, 1898 : Christmas Day. Did but little. In afternoon Frank \& I took a long walk. At seven in evening we had a company supper. It was very good. The day gave nearly all of us the blues.

Dec. 26, 1898 : Boys did not work today so we slept. In morning went to hospital to see Jim [and his] fever is bad.

Dec. 27, 1898 : Jim has small pox and a bad case. Little or no doubt but that he will pull through., Mail leaves first of next week so must write some letters. Wrote letter to mother and one to Lottie.

18 C. U. Gantenbein, p. 6 . The President ordered the relief of the Spanish garrison at Iloilo by U.S. forces on the 23rd and on the 24th the Spanish garrison evacuate the city and insurgents took possession of it. Gen. M. P. Miller organized the first brigade and proceeded to Iloilo. 
Dec. 28, 1898 : Nothing particular happened. Frank brought home camera. Frank, Carr, Mill and I went out for a walk on Lunetta and spent evening at Franks.

Dec. 29, 1898 : Took a few pictures today. In evening went up town with Brook and bought souvenir for Mamie.

Dec. 30, 1898 : Wrote up charges against Dan Richardson for own [owning a] revolver.

Dec. 31, 1898 : Went to band concert in evening. Mrs. Bowman came to see me today.

Jan. 1, 1899 : Called on Neamous folks took some pictures. In evening went to Lunetta to concert \& variety program. Was very bum. Games in a pluno were also bum. In evening many of boys were drunk.

Jan. 2, 1899 : Took long drive with Miss Bowman. Capt. was to take her but had to be at quarters. We went to Fort Malata also took in baseball game. We burned about 5 [to] 15. First time in 6 months have had a visit with American girl.

Jan. 3, 1899 : Another man sent away with small pox. This makes 3 in our company Watson, Davis, \& Ludwig.

Jan. 4, 1899 : Had 3 dozen pictures developed today. Most of them good. Washed rooms with Cailslie water. Will finish tomorrow. 


\section{CHAPTER VII}

\section{JANUARY 5, 1899 TO JUNE 24, 1899 : THE WAR AGAINST THE INSURRECTIONISTS}

From the beginning of January to the end of June, the Oregon Regiment was involved in conflicts and skirmishes against the Filipino insurgents. Bell wrote at the beginning of January about the only accidental death that occurred in the Oregon Regiment. There is a sense of urgency in his January writings that something is going to happen and Bell is unsure when it will take place. He seemed to be always ready for the action. He wrote about the skirmishes in early February when the natives engaged other state Volunteers in the beginning of the Philippine war. The Volunteers fought with the objective of using their numbers and fire power to surround the countryside and small towns where insurgent resistance was the strongest, and attempted to make Aguinaldo surrender by wearing him out. Bell discussed the capture of small towns done in late February and what it was like being on guard duty at the Custom House away from serious action around Manila and Tondo.

In March, Bell wrote about what he heard of Oregon boys at the front actively involved in the fighting. Military actions occurred around the towns of Malapat Na Bato, Pasig, Laguna De Bahia, and towards the end of the month at Malabon and Palo. He mentioned the deaths of many of his friends and how they died in action.

In April, Bell and his company are still on duty and occupied their time writing letters and getting involved in games. He told of the actions of Oregon's Volunteers at Marilao on April 11, Santa Maria on April 12, the 23 - 25 action at Norzagaray, and 


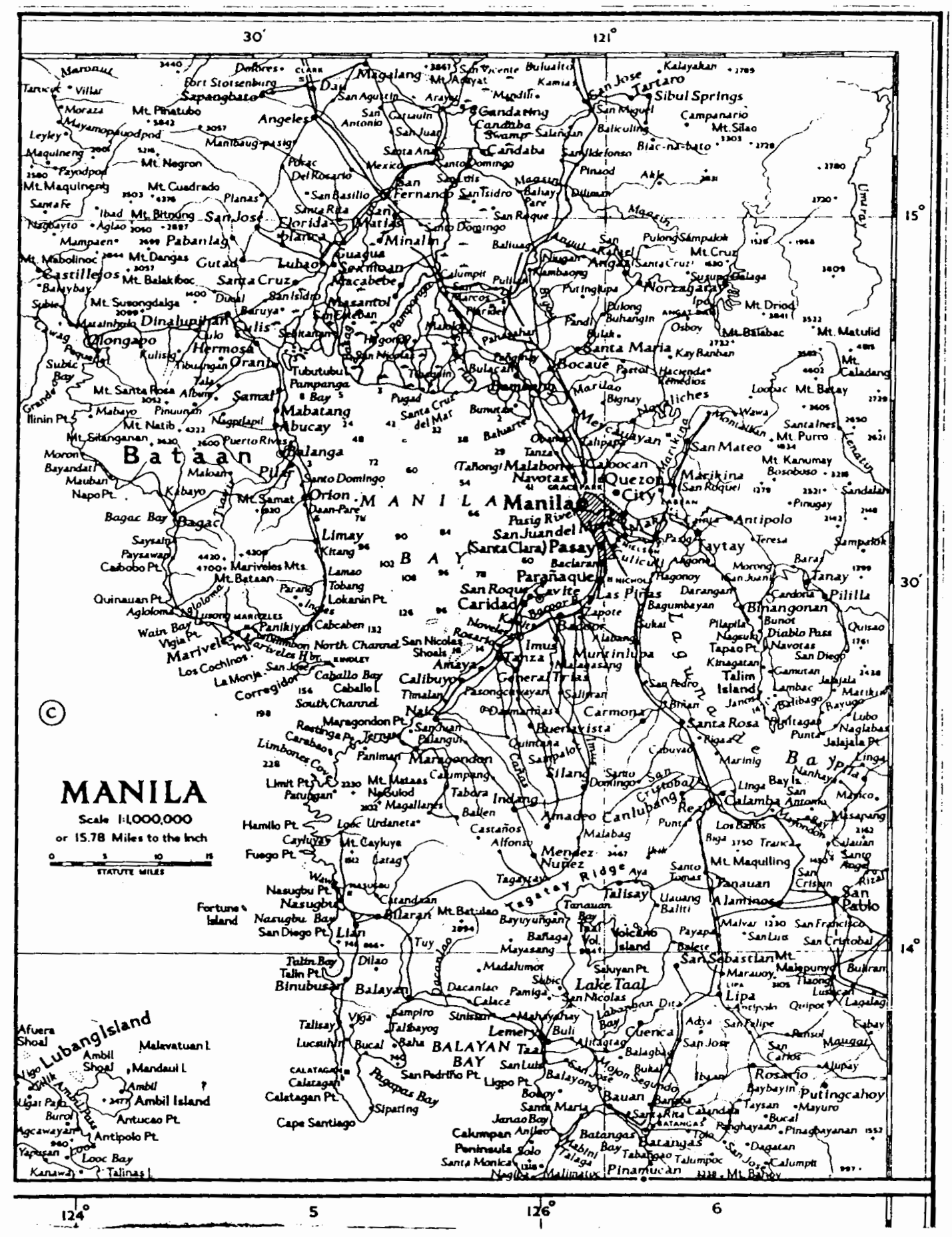

Figure 5. Manila and the Surrounding Areas of the City. Central Intelligence Agency Map. 
South

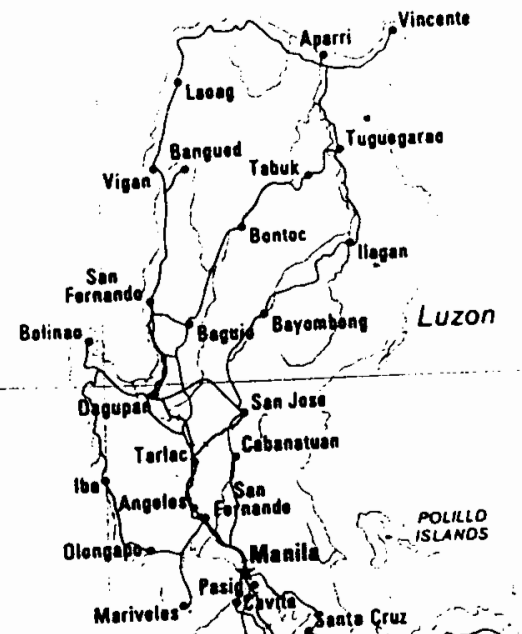

\section{Philippines}

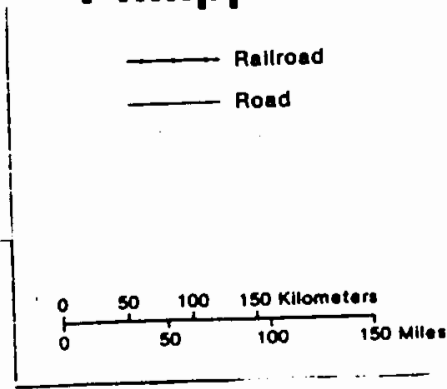

Chiñá

Sea
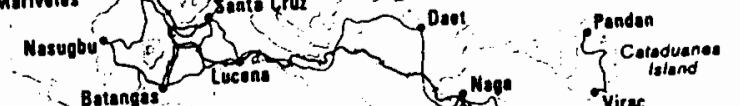

Virtace

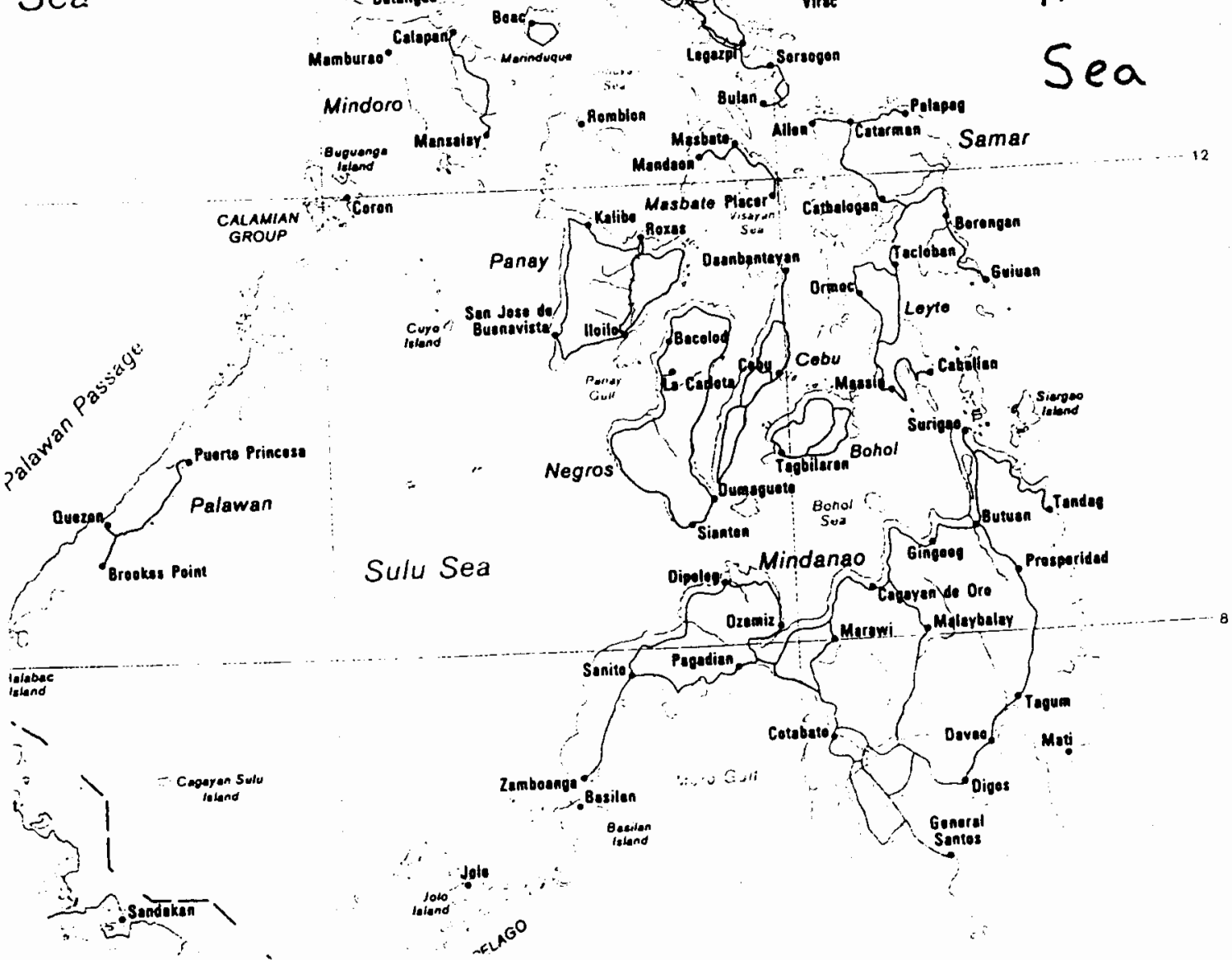

Figure 6. The Philippines. Central Intelligence Agency Map. 
Maronco on April 27.

In May, more fighting by the Oregon Volunteers is mentioned at San Rafael, Baliuag, Maasin, Salacat, Tabon Bridge, San Isidro, San Antonia, and Arayat. Bell and his company did not get involved in actual combat until June when they are part of the Morong expedition.

In fighting in central Luzon provinces during March, April, and May, the U. S. Army quickly established military superiority over the Filipino nationalist forces. In June, the army swept into the southern Tagalog provinces. Even though heavy causalities were inflicted on revolutionaries, most victories were inconclusive. Of the 26,000 troops that General Otis commanded, less than half could be used for operations around Luzon. One finds the soldiers fighting Aguinaldo's forces, occupying a provincial capital or key city, then withdrawing back to Manila. When the monsoon started in late May, there was little to show for the armies record. General Otis was forced to wait until new army reinforcements arrived in the fall before resuming any offensive.

\section{The Diary:}

Jan. 14, 1899: Had neglected to write for last 10 days although much has happened that is of interest. A few days ago in fact Jan 5, Lee Morse was killed. ${ }^{1}$ He was in New Manila during evening. I was with M. Holbrook, Freeman, and Carr [and] we last saw Lee at the Alabama at 8 o'clock. From there he $\&$ Percy went to theater and returned to quarters about 10:30 going in back gate of walled city. On [At] Maekin officers quarters they heard some shots fire wall near magazine. They stopped and spoke to sentry asking about shooting. Capt. Wells of Lee's company came out of quarters to see about shooting. Together, followed by Percy they went up on the wall. Sentry not on incline [and] who should have challenged them, had left his post looking for natives.

\footnotetext{
1 What follows is the account of the only accidental death to occur in the Oregon Regiment.
} 
Lee and Wells were followed onto wall by Major Gantenbein and Capt. Heath. None of these officers had a right on the wall as sentrys (sic) had orders that no one was allowed on or near magazines. The officers with Lee stood talking to sentrys (sic) asking about the firing for several minutes. Lee in a few minutes unnoticed left the crowd. He went up and around a small mound and reappeared in front of and about 21 feet from sentry in place where native was last seen. Without any warning sentry fired hitting Lee in ribs. Capt. Heath recognized Lee kahkie (sic) uniform but could not speak quick enough to save him. Percy meantime had gone to quarters. Lee was carried where all was done that could be but it was of no avail. Lee died in about 10 minutes. His funeral occurred next day and was largely attended by officers and men of regiment. On the 13th Percy received a furlough and started home with body.

The situation at Hola [Iloilo] the last 10 days has been critical. We sent down several regiments of troops in Puwua [Paragua with] several cruisers but the instructions of Gen. Miller was such that he did not band when he first went [into] town. Later the insurgents saw his proclamation and heard Aguinaldo's. ${ }^{2}$ Their manner changed and they fortified the city and blockaded the river by every means at their command. They spread coal oil in all principle buildings. It seems as if there may be much fighting before natives are subdued.

The situation in and near Manila is also very critical. Aguinaldo is belligerent in his attitude. The strain is so great that the shooting of a dog in the streets by a soldier a few days ago caused such excitement and such rumors to start that within 20 minutes all business houses were closed. Spaniards were flying toward walled city natives to cover and American soldiers were seizing street cars and cabs and flying to quarters. The general call to arms was sounded and in an incredibly short time from the shooting of the dog the

\footnotetext{
2 This proclamation is the same as that cited by Gantenbein in Chapter 5, footnote 18 .
} 
American forces had taken their positions assigned to them in case of outbreak. It was several hours before officers had quieted down [and] business was resumed.

The natives all over town are getting up subscriptions and leaving town for the insurgent lines. Throughout it all they in most cases seemed friendly, and consider the fact that they are in ending to fight us a great joke!! Their little joke become very serious for them if they are not very careful. The strain has caused us, $\mathrm{Co} . \mathrm{H}$, to use guards at night. We have 2 posts and 4 reliefs, posting guard from 9:30 to 5:30 so each relief has but two hours. I act as corporal sleeping downstairs where and [I] can be awakened easily in case of emergency.

The work at Custom House goes on as usual. I have taken about 4 dozen pictures \& have copies [and] have done well with them. Watson, Davies, \& Ludwig, the small pox patients are doing well. Yesterday met an Mexican girl. Daughter of American Capt. She has a america (sic) [accent and] I went with her \& Mr. Peters to the photographers. I have some picture finished. Will probably go out and shop to see her in few days. She expects to be here a week more. Nurses have come ashore but have not yet called. Will soon.

Jan. 15, 1899 : Rain bad. Force we [Forced us] in quarters all day. Was to go see the Ilhambra [Alhambra] flower girl but was to wet. She seems to wish to pull my leg.

Jan. 16, 1899 : Went to hospital to see Jim. He has blotches all over face but they will disappear in a few months. Jim will be in quarters in few days. Had Andres skipped [skip] out with $\$ 65$ American Company money. All is quiet in regard to natives. I do not believe there will be any fighting. Regulars are on their way here presumably to relieve volunteers. We may be home in a few months. 
Jan. 17, 1899 : Took orders for pictures. Jim came home today. Went out to graveyard and put flowers on Illivas grave. Howers was sent home ${ }^{3}$.

Jan. 18,1899 : Lay around quarters all day \& evening.

Jan. 19, 1899 : Ordered copies of pictures. In evening went to call on Mrs. Bowman and other nurses.

Jan. 20, 1899 : Usual round of work. Much joshing about [having] no clothes etc.

Jan. 21, 1899 : Went to Corrigedor (sic) [and there is] not much to see but old fort. Did not go up to lighthouse [but I] took two pictures of native village.

Jan. 22, 1899 : Sunday. Lay around quarters with bad throat all day. Sunday. Billiards in evening.

Jan. 23, 1899 : Nothing of interest. In evening we went with Claggett, Watson, \& Morrow \& played game [of] billiards.

Jan. 24, 1899 : Mail expected in 2 days or so. Wrote to mamma, Lil \& Barton. Kerrigan's 21 st birthday [was today and] about $1 / 3$ of company was drunk.

Jan. 25 to Jan. 30, 1899 : But little happened in the last few days. Mail came on the 28 th. It was very small mail. I received nothing [but] as the 27 th mail arrived I received 3 bibles, one from Harvey, one from Mr. Reid, and one from mame. The boys

${ }^{3}$ No mention found of a "Howers" and no "Howard" or "Howell" leaving on January 17, 1899. 
spent my $\$ 3$ for Christmas and I was to go back to the office. This is good news. Carr, Jim, and Frank \& I had dinner on the $\$ 3$. There seems to be little or no doubt but we will leave for home sometime in March.

Have been playing billiards a good deal of late. Like the game very much but find it somewhat expensive for a poor player. Have done but little reading the last two weeks but hope to finish up Addison's Spectator before we leave the island. [On] our trip home [I] shall read Laws of Evidence again. I shall also take up my shorthand in June. Boy there has been but little sickness in the company for some time and the little there was is a light nature. Last night Ball ${ }^{4}$ fell down the hatchway, it was shit. He cut a 6 inch gash in his scalp. It came near being a fatal accident but some thing broke his fall of 15 feet \& he was nicely gazed [dazed]. I received a few days ago some 110 copies of the pictures I have taken will probably get the remainder this week. Boys are forming a sort of Glee club. We have very good music [and] nearly every evening.

Jan. 30, 1899 : Went to see Pointdexter [who is] Cox's cousin. He is under arrest again for leaving his guard, Freeman or I will probably defend him. He will surely be sentenced for he [will] have to admit the charge. Prurous [Price's] ${ }^{5}$ conviction will also work against him. Received mail. One letter from mame \& one from mother. Home people expect to see us out of here soon.

Jan. 31, 1899 : We [were up] early [and] all men were out in boat today so had to remain around and did not get a chance to work up Prints [Price's] case. Reading Addisons [Addison's] Spectator part of the time. Must Finish soon. In evening went to

${ }^{4}$ C. U. Gantenbein, p. 375. Edward J. Ball, Co. A, 29, Post Office Clerk, Private

${ }^{5}$ C. U. Gantenbein, p. 362 . Frederic Price, Co.M, 29, Blacksmith, Private. Was tried by a summary court for violation of $32 \mathrm{nd}$ art. of war (absent without leave). Sentenced to forfeit $\$ 8.00$ for time absent and was deducted on pay roll. 
see Capt. He is sick. Probably Malaria fever although he has some symptoms of small pox. Rumor says we [may] be away from here before March 1st. Do not believe it. B Company man named Murray ${ }^{6}$ was down in evening $\&$ did some fine clog dancing.

February 1, 1899 : Pointdexter was tried before a summary court [in front of a] Lieut.Col. He was fined $\$ 10$ making no defense. Think it was a surprise to him as General Court Martial was expected. Capt. McDonald was sick with fever. Not yet serious \& we expect it will not be as he was better in evening. Mail leaves tomorrow but will send no letters.

Insurgents last night advanced on the Nebraska outposts they fell back according to orders so as to avoid trouble. The insurgents who made the advance are not directly under Aguinaldo \& want to fight. [Gen.] Otis hopes to arrange matters peacefully so will not oppose them with force until it becomes necessary. It seems to natives [our] policy gives false idea of us. Makes them think we are afraid so gives them much confidence if trouble ensues [and it will] finally will make that much harder work to subdue them. There was no general call to arms last night but several regiments were under arms. Our mess is no so good it was when Ferlnabador [Fehrenbacher] ${ }^{7}$ first took hold. He is somewhat close $\&$ seems to wish to make a stand as a money saver instead of serving fine meals. We ate much better under Pratt than under Fernbacker (sic) we now get very little but government rations although there is something like $\$ 400.00$ in food.

Feb. 2, 1899 : Capt. McDonald better. Went out in the forenoon to milk ranch to get him some genuine cow milk. Was told to come again at 3:30, did so \& got the milk.

${ }^{6}$ C. U. Gantenbein, p. 130. Thomas H. Murray, Co. B, 29, Stonecutter, Corporal.

${ }^{7}$ C. U. Gantenbein, p. 271. W. Fehrenbacher, Co. H, 24, 21, Clerk, Corporal. 
Paid 200 for one glass to drink. First milk I have had since leaving Portland eight months ago.

Before getting milk I rode out to the outpost where Washington troops are located. It was there the natives made demonstration the night before. All was quiet. Few sentrys (sic) are within 200 feet of the natives. I took two pictures one of the blockhouse and one of native guard \& guard house. The demonstration They made was simply to advance and as our troops did not retire but were set in, [they] forced $\&$ formed skirmish but the natives retired. Understand our boys have orders not to fire under any circumstances but in case of determined advance [they are] to retire in good order. This I understand are [is] because Aguinaldo hopes of settling difficulties without bloodshed. The troops near the Washington boys are not Aguinaldos [Aguinaldo's] personal force but under another insurgent leader. He wishes to fight $\&$ it seems hard for Aguinaldo to hold him down. In the evening Freeman, Walker, Pointdexter $\&$ I went out to call on the Army Nurses, not Red Cross, we found at home Miss Bowman, Miss Dunsh, Miss Carhast, \& Mrs. Biddell. We spent a very pleasant evening. Took a walk etc. Also saw Miss Killiam \& Mrs. Antwood but the government nurses do not jibe with the Red Cross.

Feb. 3, 1899 : Nothing out of ordinary happened today. In evening Carr, Frank Holbart \& I played billiards. James during day played Shorty 3 games chess Holbart [won or lost] in every game James [Then] in evening about 9 we were all [done for] today [and] we walked out [to] Whalleys when we heard the call to arms played at California quarters just across the river.

We started to quarters notifying the boys we saw. Just a few minutes after our arrival the boys came from the circus $\&$ told us they had heard firing in the outposts. Some [Soon] we could hear the firing it was general although the [in our] bones we were just ready to go. Slept with clothes on. I was Corporal of Guard. Firing continued all night. Several shots coming very near in the Buttels were found in the morning. In early morning 
Dewey opened on woods with some of his guns. Cannot yet tell results but believe found all that can be learned [that] the insurgents were driven back all along the line. We went [and] lost some men. Dont [Don't] know how many. There has been no general uprising in town but wounded men returning from front \& policeman \& others etc. have been set upon by 8 to 10 natives, 7 in several instances badly wounded or killed. 8 The beets in position as now being cause as to prevent this. One of own sentries was shot at. It came from river probably from Ciscos attack the [we] are learning something about fighting. With proposal, [we] fire across, which they did not before know if we have call. ${ }^{9}$ Question as to final outcome but we may have some severe fighting. Tomorrow we will know something of todays fighting.

Feb. 6, 1899 : This morning reports show that our [troops] advanced driving natives before them. Most of the firing at night is by the natives answered by and [an] occasional volley from our men. But at daylight much to the purpose of the natives who expected us to remain quiet, our men opened fire at the same time. Dewey let them have it. The result was something awful. Natives were killed by them by the hundreds. They did so much shooting from bamboo huts that an order came to fire the huts as the men advanced. This was done \& men, women, and children suffered. The natives are but poor fighters \& do not understand our style charging under fire. Freeman was in the thick of the fight but was in the company and could not get away.

8 Ibid., p. 55. In the Paco district of Manila Filipinos were firing at soldiers in the rear and at ambulances with wounded soldiers in them. That afternoon Companies D and L, under Major Gantenbein took a patrol. Along skirmish line was formed and a march through the Paco zone was done. They drove from the zone all who were bearing arms and captured forty-five men who were strongly suspected of being the ones doing such firing. Some of them were caught in the act of casting their weapons into sloughs. Four or five of these natives tried to escape and they were the ones shot.

${ }^{9}$ Apparently what was being done was a chivalrous action where warning would be given of firing so the defenders could try to prepare to seek safety. 
In the evening I got permission of the Capt. to take a walk. Carr, Jim \& I started and we met Dustin \& ( ? )dale who joined us. We started for Kansas lines but got on a road which finally led in the jungle \& stopped. We could see a quarter of a mile to our right a big hut on fire so we retraced our steps. ${ }^{10}$ Crossed a rice field on the dikes and reached the fire but if our men started it they did not remain now. Just before reaching fire we ran on a hut. The inmates were watching fire on seeing us they began to yell "Buenos Noches, Onega Cara Beno." They were nearly frightened to death. From the fire we soon ran across the main wad \& soon met some boys of G. Co. Kansas going to the front with blankets. We went across with them but once ran off the road \& ran into Montana outpost. We turned back \& in about an hour reach block house where Kansas Co. was located. It was on top of a hill to left of church where 3rd A battery was sited at. We could see but little and there were only a few stray shots fired so we did not go into action. In the return we got a ride in as far as Bibi Bid We got back about 12 \& went on guard at $4 \mathrm{~A}$. M.

Feb. 7, 1899 : Nothing of importance happened during the day except arrest of all men who went to front without leave including Morrow, Watson, Clagget, \& Pratt. In evening 2 natives were shot within 30 feet of me apparently no cause as neither of them had any sort of weapon. On guard all day.

Feb. 8, 1899 : On guard all day. Privates who left without leave were fined from $\$ 2$ to $\$ 7$. The non coms I think got a severe lecture because of charges were preferred a General Court Martial was necessary. It is rather hard on privates to be fined and non

${ }^{10}$ C. U. Gantenbein, p. 56-58. His partner with Dustin cannot be deciphered because of the next page print that shows up through to his writing and marks up the beginning of the name. The fire was started by incendiary origins. It broke out in the Santa Cruz district. Three blocks were burned toward the center of the city, in the Chinese quarter. A few days later on the 22nd there was an insurgent attempt to burn Manila and on the 22nd, flames began to leap up from the Tondo district, where Co. C of the Minnesota regiment was quartered. Shooting broke out in the effort to reach and put out the fire. The whole Tondo district became infested with Filipinos carrying arms with their purpose being to cut off the Minnesota boys. Co. $\mathrm{H}$ of Oregon came to the rescue of the Minnesota regiment and they cut off communication between the large force in Tondo and the scattering sharpshooters. 
coms let go with a talk. Shorty, Pratt, Coyine, \& Hampton all tell of a very exciting time. Hope I'll get a chance to see some action.

An incident happened which showed native character. During the battle one of Aguinaldo's Generals who took part in Peace conference appeared with a flag truce. It was answered by Col. Crowder [Major Cardwell] \& Col. [Q.M. Sergeant] Potter who also took part in peace conference. The American officers advanced to near the insurgent lines $\&$ were met by officers. Immediately after insurgents fired on the crowd. When our officer demanded of insurgent officer what was meant by firing on flag of truce he answered, almost in ha [laugh] that he was forced to admit that his men were untamed savages without the first principle of humanity and apologized for being a part of such a disgraceful affair $\&$ asked to be allowed to retire. He himself was pured on by his own men. The chances of the Oregon regiment $\mathrm{Co} . \mathrm{H}$ in particular going to the front grow leanfully less each day. Was on guard all last night nothing very exciting happened. There was more fighting at the front. 11

Feb. 9, 1899 : Nothing had happened today. The usual round of work \& guard duty. In evening put on extra guards as outbreak was expected. The non coms who took trench leave were reprimanded by Clagett \& Capt. Mc [McDonnell] was very cool to them but in evening he took up their regulations played crib with short $\&$ said let by gones be by gones. Privates were all fined from $\$ 2$ to $\$ 10$. Little now fighting.

Feb. 10,1899 : Last night American forces captured two small towns ${ }^{12}$ \& California [was] fighting in left was severe but insurgents were licked. At one place center of our lines fell back purposely let insurgents in then caught them on the flanks \&

11 C. U. Gantenbein, p.7. General Miller was directed to take the city of Iloilo.

12 Ibid. The two towns were Caloocan and Iloilo. They were fired and abandoned by the troops and were immediately occupied by U.S. forces. 
slaughtered them. Another hospital man killed. This makes three I think. A few days ago 6 natives were shot for firing on hospital wagon. We were issued one days rations \& rolled blankets yesterday as outbreak was expected and we had some hopes of going to front but as our lines were strong enough we were not sent $\&$ fear we will not be.

Feb. $11 \& 12,1899$ : Nothing happened but usual round of duty. Several boys are off ships so guard work is less heavy on me. No province boats are allowed to leave harbor. Skirmishing goes on at front with but little loss in either side. Will try and take camera to front tomorrow.

Feb. 13, 1899 : Went to left of our line today. Took 5 pictures. Was under fire nearly all day but was not allowed to return fire. Lieut. and some regulars did shooting. Battery opened up once. Several of our men wounded.

We were in plain sight of Malabon. Passed through Caloocan. Battery on river just outside of Caloocan. The line out from town is a desolate sight. Houses burned. Huts shot down wearing apparel scattered round. Dogs howling. Deserted inturshments [instruments]. Cartridges scattered on edge of town while flags at each hut nearly all deserted. Soldiers chasing pig. Soldier drinking glass water saying :"Would it not be funny if a shot should knock the glass out of my han." Just then tymn zip and a bullet came so to him that he choked himself in dodging. Everybody dodges. One Corporal, a tall skinny fellow went out in front of trenches in plain sight but no one fired at him, I was with Barrett, Kaltz ${ }^{13}$, \& Hill. Returning came in on railroad. Visited and took pictures of battery. Ho Ho [Binondo] fell today. No men lost.

13 C. U. Gantenbein, p.271. Bruce Kaltz, Co. H, 21, Clerk, Corporal. 
Feb. 14, 1899 : Valentines day. Miss Bowman sent me some candy, cigar case, and handkerchief. Have not sent hers yet. I am her orderly. Took pictures to Cheenu photo says he will finish them in a week. Played Anderson two games chess. First he gave me queen. I beat. Second he gave me Castle. He beat. Both games were close.

Feb. 14-20, 1899 : Some round of duty for us the last few days. As little skirmishing At the front but nothing of great importance has happened. Have been feeling miserable for some days. Dr. Christiansen has been treating me. Think he is O.K. Mail comes today. Have played several games of chess. Guess I have not won any but can see that I am improving see new points and enjoying the game every time I play. Have got most of my pictures \& will get remainder today if I can raise the money.

Feb. $20-26,1899$ : Have ben sick since last writing. Got pictures on 23rd. Nothing has happened except on the night of the 22nd when outbreak was made and attempt made to burn. The attempt was partly successful the Native huts and several blocks in Tondo district. We were called out and went to Calletries [Caloocan] where we saw some active work. Got some tools then did patrol duty.

Feb. 27, 1899 : On guard. Everything quiet. Hook beat me three games chess. Wrote to Mamma, Reed, \& Hogue \& Kenneth Rummy.

Feb 28, 1899 : Muster \& Inspection at 7 AM \& 11 AM One of our guards, Kerrigan, shot at a Philippine last night but with no result $\&$ no particular news. Mail should be in in a few days. No news from front. 
March 1, 1899 : A little skirmishing at front but nothing of importance. Usual round of work in town. Still kept in quarters and not allowed uptown. Yesterday started to read Smiths Mercantile law.

March 2, 1899 : On guard as quartermaster. Everything quiet. Still kept in quarters. Little fighting at front.

March 3, 1899 : Still playing chess. Can see but little improvement. Wrote letter to Lila today. Must write several others before Monday. Usual round of duty \& everything quiet.

March 4, $1899^{14}$ : Wrote letters nearly all day. In AM to Lila and started one PM to Farret. Was on guard during night. Have been bothered with cramps for several days. Senator came this AM with part of 22 regulars. Ohio expected tomorrow with remainder also mail. Senator brought a little mostly from Hong Kong. [The ship] Scandia came yesterday with supplys (sic) and officers wifes (sic).

March 5, 189915 : Mail came with remainder of troops on this I got letters from officer \& home. Was on guard part of time. Cramps still pretty bad.

14 C. U. Gantenbein, p.61-63. Sharpshooters along the water line were bothering nightly the outposts and Major Eastwick was to make an excursion to clear the country. They met the enemy in force at Cruznalis for five hours. Corporal Panath of Co. G was shot in the right lobe of the lung but recovered.

15 Ibid. Captain Moon sent 24 men to clear the woods along the Mariquina road three miles from the area defended by the Oregon men. The railraad ran North from Manila to Dagupan on the Lingayen Gulf 120 miles away. The village was taken at right angles to the road. The Filipinos had an ambush planned and saw the men and fired on them for about a half hour then tried a flanking movement. Capt. Moon went to a little ridge and was reinforced by three companies that was to be their rescue. The excellent firing of the regiments caused the Filipinos to flee in panic. 
March 6, 1899 : Oregon Batt [Battery] in an engagement under Major Eastwick. One man wounded. Boys did good work. Natives made an unsuccessful attempt to force center of our lines. I will play in chess. Seems to progress some. Battery came in from boat last night $\&$ one opened up his box. There was a box of candy from her sister for me and several others. On guard last night.

March 7, 189916 : Pay Day. Soaked $\$ 25$ with paymaster. Was on guard at quartermasters. Atwood was drunk \& slept on post arrested being but believe they will not soak him.

March 8, 1899 : Little has happened out of the usual run. Miss Bowman passed today and called for a few minutes.

March 9, 1899 : Huck Stansberry was ordered to Frisco probably for a discharge. Leaves Saturday. I send by him a spoon for Mamma. He also beat me several games of chess. He plays to (sic) strong for me yet. I heard Dodge [may] also leave tomorrow. 17 Mail expected today.

March 10,189918 : Oregon regiment ordered to pack up and be ready to move into quarter Espana. No mail.

${ }^{16}$ Ibid. After resting a day Companies $\mathrm{G}$ and $\mathrm{K}$ moved against the Mariquina village. They dispersed all opposition in the vicinity and burned what was left of that place.

17 Julian Dodge does not leave.

18 C. U. Gantenbein, p.17. First and Second Battalions ordered to join Gen. Wheaton's flying column for the Pasig campaign. 
March 11, 1899 : The three boys left this A.M. Oregon regiment goes up river to drive natives from that part of country preliminary to general movement. ${ }^{19}$ Lawton came yesterday on [the ship] Grant with regiment of 4 th infantry \& one battalion of 17 . Still no mail.

March 12,189920 : Company A does not go into regiment in flying squadron. All their things are packed and stored at bottom in $2 \mathrm{M}$ Dpt. [Department] [,] but they will have to remain. Mail did not come today probably tomorrow. Boat guards all have to wear a band on cap on which is printed U.S. Custom House. Jim Watson again returned from hospital. Perkins will get his discharge. Small fire yesterday but not large enough to call out troops. Now that regiment is gone $\&$ we are not going all $\mathrm{H}$ company boys are ready to go home. There seems to be some scheme to have volunteers to re-enlist either individually or as organizations. This may mean compulsory enlistment for 6 months, unless it is compulsory none of our boys will reenlist.

March $13 \& 14,1899$ : But little out of routine has happened. Oregon boys are fighting well at front a few are wounded. 21 Dodson was wounded in foot and while stooping over to examine it was shot through cheek of ass. Wounds not serious.

${ }^{19}$ A flying squadron means stripped down light infantry that was part of this general movement.

${ }^{20}$ C. U. Gantenbein,p.17. The two battalions marched from Manila to San Pedro de Macati at 3:15 P.M.

21 Ibid. Oregon Volunteers advanced upon Guadalupe at 5 A.M. with Fourth Calvary, Twentieth, and Twenty-second Infantry. The enemy was repulsed and volunteers camped at Malapat na Bato. The next day Companies E and I under Major Willis crossed the river and engaged the enemy opposite Pasig. They returned at 3 P.M. Companies B, D, and $L$ under Major Gantenbein, engaged all day from the bluff overlooking Pasig. 
March 15, 189922 : Troops still advancing. Watson to go home on next transport. Manning sick with dysentery. Jack Spurings died last night of dysentery.was buried at 2:30. Mail came in evening received letters from Mamie \& Lil forgot to give Girlies address. Centennial came in with government supplies.

March 16 \& 17, 1899 : Still no mail. Wheaton brigade continues its advance meeting with some resistance but never stopping. More or less firing going on along the whole line but it amounts to little on either side. ${ }^{23}$ Minn. are to be relieved from provost guard.

Monday 20th reg to take place. 20th was with flying squadron but have not become acclimatized so could not stand work \& were rapidly becoming sick. All will without doubt be relieved in a day or so and join regiment at front leaving only $F \& H$ in with little or no hope of their gain [getting] out. Mail comes today.

March 18, 1899 : Mail arrived. I got 3 letters one from Annie Reid. She is to be married in April. A \& F company say they are to be relieved \& go to front. They also say H will go but I doubt it. ${ }^{24}$

22 C. U. Gantenbein, p. 17, 67. Companies D and M under Lieut. Col. Yoran advanced with a wagon train two miles. Companies $\mathrm{E}$ and I under Major Willis crossed river again and engaged enemy opposite Pasig a mile in advance from yesterdays position. First Battalion was still engaged from bluff near Pasig. Just how many Filipinos were killed could not be ascertained but it was believed that the number was large.

23 Ibid. The First Separate Brigade engaged the insurgents at the Jaro bridge and at Mandariao. Two companies of the Colorado Volunteer Infantry attacked a body of insurgents retreating from Canita and drove them through the town of Mariquina. On the 17 th Gen.H.W. Lawton relieved Gen. T. M. Anderson in command of the First Division.

24 C. U. Gantenbein, p.17. Co. D was sent to relive company of Washington regiment at Taguig. They captured and burned the town when they arrived. Companies B, D, E, I, and L under the command of Col. Summers, and Majors Gantenbein and Willis, started early that following morning on the longest march of the Philippine Insurrection campaign. From 6 A.M. to 11 A.M. the line swept steadily forward and cleared all opposition that was found. They kept moving till the afternoon at Malapat na Bato completing a march of twenty five to thirty miles. They had carried ammunition, rations and a full 
March 19, 1899 : Flying squadron continually advancing. Went 20 miles yesterday came back to quarter Espana it is afternoon. Gen. Wheaton says "That damned reg can be sent any damned place." Hope we may be able to join regiment in ten days but I fear not . No particular news.

March 20, 1899 : Mail left today. Sent one letter home. Brook \& I went up town with mail. Ate dinner at English hotel. After dinner took in Peinya cloth stalls. I bought 1 Housa apron, 1 Housa Handkerchief, 2 Peinya handkerchiefs, [and] 3 Peinya Doilies. Shoudan came in five days ago. 1 whole division is to be rebrigaded. Oregon will be relieved from Provost guard \& put in 3rd brigade until Gen. Hill May. Gen. Anderson is to go home. Co. H will probably be backed from brigade \& reg. \& kept at Custom House. 25

March 21, 1899 : Reg. camped on Luenelro [Lunetta]. Boys all tired and sore footed. Do not know what is to happen next. Rumors of all kind afloat. Everyone seems to believe $\mathrm{H}$. will be relieved. I dont [don't] think it also will not be lines. Shaudon did not come up but is expected every day. Another battalion of Cal went to negros.(sic). ${ }^{26}$

March 22, 1899 : A man arrived with 1200 odd troops by way of Suez. ${ }^{27}$ Telegram came from War Dept.asking if it were not possible to send an organization home

haversack and their Springfield bayonet all in the hot season of Luzon making their achievement more remarkable.

25 C. U. Gantenbein, p.68. The regiment returned to Manila.

${ }^{26}$ C. U. Gantenbein, p.9. Companies F, G, L, and M, First California Infantry sailed from Manila en route to Bacolod, island of Negros.

27 Ibid. That expedition was under the command of Col. J. H. Page, Third U. S. Infantry. They had sailed from New York on February 3 via the Suez Canal. 
on Grant as guest pass was being made at home. This [was] replied "No Hunters can be shipped at present will send them home as soon as possible." Mail leaves tomorrow on Grant Watson is not yet discharged or ordered to be so.

March $23 \& 24,1899$ : Reg. getting ready to move. H was not go, was ordered relieved, but orders was countrimanded (sic). We'll have to stand considerable joshing. Had some punch [at] dinner last night. Fellows made much noise $\&$ fuss so I suppose had a good time. Perkins goes home tomorrow. Mail arrived. Got letter from Dottie. Pratt left for Colocron [Caloocan] this A.M. Will probably see lots of fighting before returning. Capt. thinks we will get to front before we retum. ${ }^{28}$

March 25, 1899 : Big battle occurred today. Worst of war. Gen. Wheaton's brig. [brigade] on left of line comprising Oregon \& three other reg. [regiments] made a demonstration before Malabon while Gen. McArthur moved whole division around and by Malabon so at present both wings of our army rest by Wabu surrounding Malabon in crescent formation. ${ }^{29}$ Otis telegraphed home he expected to capture 14,000 [in] a day or two. Oregon boys were in heaviest of fighting wading through marshes and climbing

28 Ibid. Companies C, F, G, and $\mathrm{K}$ were in the movement. Soldiers were happy because they were in Wheaton's brigade because that insured a fighting position.

${ }^{29}$ C. U. Gantenbein, p. 69-73. The fighting was very dangerous and many were killed. At Malabon, there was a channel separating that city from the mainland. Oregon was in the pivot point. The territory to be covered by the extreme right and center was to require nearly a day. The plan was to have Oregon move late in the day on the 25 th, the attack started instead at 8:30 A.M. There were heavy fortifications that the Filipinos had developed. The initial fire in the attack of the first trenches was intense and several boys of Oregon did fall. The Filipinos tactic was to make a stronger stand further back where greater numbers were. Greater obstacles had to be overcome and most of the land in the second and third trenches was marshy with few accessible roads. Going through thick bogs that had footing on either side was nearly impossible for Captain Wells to find for his men and several were killed at this point. The last line of retreat for the Filipinos was the Tuliahan river east of Malabon. Filipinos tried to find shelter in the brush and ruins between the trench tunnel and the river. General Wheaton called for an orderly this time seeing how fast Oregon had moved over the required ground and said to, "Catch those Oregonians, or they will be out of the country before we can stop them." 
breastworks in fine style. We lost about 45 killed and wounded. Among dead are Ben Fayln [Fane], Guy Millard and several other of boys I knew were killed. ${ }^{30}$ Luis Brazee and young were wounded. Millard had dysenteria [dysentery] but went with regiment because boys of his company called him cold feet said he was not sick but afraid to go. $\mathrm{He}$ was killed while marching a useless though ordered charge down in expand causeway. As he fell he said "You boys can see I am no coward now" and died. Nothing worth noting today.

March 26, 1899 : More fighting on lines. ${ }^{31}$ Oregon boys lost several more men Freeman, Holbrook, O Neil [,] Jarman and others wounded. Did lots of charging but no firing. Malabon was evacuated by natives $\&$ burned. It is expected a big fight will be made today. Our lines from a crescent both ends on the water. All troops have left city and are on lines in a ciet [crescent]. As reserve no chance for us. A bomb was discharge in street last night. It was probably intended to destroy some soldiers quarters but did no harm cept [except] put out electric lights on one circuit.

March 27, 1899 : Oregon boys rested yesterday but fighting continued on right of line. We lost about 14 men killed \& 70 wounded and advanced our lines to within a few miles of Malalos [chief city in Bulacan] which is expected to fall today but a heavy resistance is expected. Beat Jim Watson 3 games chess evening putting me one in lead.

\footnotetext{
30 Guy Millard's death that Bell writes about is one of the saddest and most unjust ways to have a man die in warfare.

31 Ibid. There was a scouting party sent out early in the morning of Co. A and Co. L men totalling 11. They crossed the water and entered Malabon itself. They took down the entrenchments put up in the night and saw flames coming from various quarters. They tried to put out the flames so they would not be surrounded by insurgents. They found out that 3,000 insurgents had just left the city thinking the scouting party was the first of the regiment coming in and the Filipinos had started burning the city so the victors could not have it. The Volunteers marched to Polo and again had to go through a serious fire and face Filipinos in their circular trenches. The nerve of all the officers and soldiers was recorded to have been tested because the ammunition fire was so heavy.
} 
Brook beat me 2 out of 3 . Small mail today. Eight $\mathrm{H}$ men put in jug for going to front without permission. Coyne gets two weeks. Coleman 4 days. Others between. Those in are Sam Holbrook, Coyne, Bodley, Davies, Kerrigan, Taft, Fremont, \& Coleman.

March 28, 1899 : Sent home letters maps and papers of the fight. Malabon has fallen \& troops are near Malolos where it is now expected a hard fight will be made. Oregon after a rest of two days will again advance. Mail held at P.O. came today. Got 5 dozen films.

March 29, 1899 : More mail. One from F. Grant now have charge of Guard House. It is a thankless job. Everything is quiet at front except for rumor that the insurgent general Monteney is killed or wounded.

March 30, 1899 : No news from front and same old story here. Am kept very closely at Guard House now and will get in some good reading on law books.

March 31 - April 1, 1899 : Another attempt to burn town was expected but failed to materialize. Rumor says regiment will come in action in a few days.

April 2, 1899 : Albert Springs leaves for home today. Send box of Pina \& Housa by him. Everything quiet at front and at lines. Got one letter from home yesterday.

April $3-4,1899$ : Everything quiet in town and at front. Usual round of duty. A chess tournament has been started in company. Players are divided into 3 classes. A class gives $\mathrm{B}$ class a bishop \& $\mathrm{C}$ class a knight. $\mathrm{B}$ gives $\mathrm{C}$ a bishop. A class players are Smith boys Anderson, Coleman, \& Wade. B class Watson J., Clagett, Holbrook, Truman, 
Barrett, Harder, Walker, \& myself. C class Morrow, Little Herb Watson, A. Patterson, \& Pierce.

April 5, 1899 : No news. [I] played several games of chess. Won one from Holbrook lost one to Watson. Sent up town in afternoon. Called on Miss Bowman [and] took her picture [and] we went downtown and had a soda. Saw Mrs. Biddel, Miss Durm, \& Miss Earhart [and] met another nurse never heard her name. They will soon give a town party and Mrs. Biddel to go to Capt. \& Mc [McKinnon] to let some of us go.

April 6, 1899 : Everything quiet in town and at front. Rumor says that we will soon make another advance on natives. Played Jim two games chess in toumament series. Lost both. Played Shorty one game. Outplayed him but made a poor move \& got a stalemate.

April 7, 1899 : George Miller shot last night. He was drunk uptown without permission and was arrested by 20 th man. In trying to escape he was shot. Have not yet heard full particulars. Everything quiet at front. Mail came in yesterday. Received announcement of C. Rockwell engagement.

April 9, 1899 : Alls quiet at front. Was sick for several hours last night. Must have eaten something that went back on me. Drew some clothes yesterday One hat--One blue shirt.

April 10, 1899 : Lay in bed all day yesterday. Feel much better. 
April 11, 1899 : Everything quiet. Expect Jim to go to Corrigedor. He seems some worse. Oregon \& Minn. outposts have all attacked last night. ${ }^{32}$ Oregon lost 3 men killed two wounded. The outpost was of five men they were surrounded and could not be reached by company because that was also surrounded. For a while it looked as if Heaths battalion was a goner but he held them off till morning when help came. Co. D \& E of Oregon went to assistance of Minn. Co. or they could have been annihilated. Gen. Lawton crossed Lake [Laguna de Bai] and captured Santa Cruz. City next in size to Manila.

April 12, 1899 : Everything quiet both on lines and in town. Santa Cruz was captured by Lawton with no trouble \& Santa Maria by Oregon \& Minn. Ornegas ${ }^{33}$ have caused so much trouble \& murdered so many of our boys that they recognize them no longer but shoot on sight all natives. Natives will not or cannot understand kind \& civilized treatment. If you treat them as equals they will think you are afraid of them \& murder you. Several lands of hostiles captured. ${ }^{34} \mathrm{~A}$ truce flag is to them nothing. Out a ruse to get near our troops and fire on them with safely to themselves. They also [fight]

32 C. U. Gantenbein, p.81-84. It was estimated that 1,000 Filipinos moved down to the city of Bocaue where the Minnesota and Oregon men were stationed. Fighting was to the North and the men were coming South. Oregon men fought the night and next day and captured Santa Cruz. Oregon and Minnesota captured Santa Maria. Oregon came to Minnesota's assistance and came across 150 insurgents leaving Bocaue and the senior Minnesota officer ordered Oregon's Lieutenant Dunbar to not fire because he thought the insurgents were American troops. Firing did occur and 19 insurgents were killed. It became evident that the insurgents making the night attack came from Santa Maria and were probably guided by some of the friendly Filipinos who had been coming daily to the camp for food. General Wheaton planned to destroy the city. The General took Companies B, I, and E of Major Willis battalion and Companies A and L of Captain Heath's. They marched through Pandi and then Santa Cruz and destroyed them both putting the armed natives to flight.

33 Ornegas was his name for one of the groups of natives that occupy the Philippines.

34 C.U. Gantenbein, p. 10. The towns are Pagsayjan, Longos, and Paete. 
contrary to all civilized warfare make it a point to abuse his figure ${ }^{35} \&$ kill all wounded [and] torture all captured \& shoot all hospital men.

April 13, 1899 : Everything quiet Troops expect to move in Calumpit Saturday.

April 14-15, 1899 : Still everything quiet. No move yet made on Calumpit. Penns [Pennsylvania] came in front line \& I was to take their place. Everything points to some volunteer troops going home. One [on the] Sheridan which will leave within a month. Spoke to Capt. about getting a job in Custom House says he will do what he can.

April 16, 1899 : Sunday. All quiet. Davies go to front and Penns. take their place at Cavite all sorts of rumors as to home going.

April 17, 1899 : Wrote letter home. Alls well on lines. Expect to go to Custom House to cook in a day or two. Mail expected soon.

April 18-21, 1899 : Nothing to note in last three days except mail arrived yesterday and massing of brigade to move down valley. Now Col. Summers is in charge of brigade. All quiet.

April 22, 1899 : All quiet today. Our troops begin river movement. ${ }^{36}$

35 C. U. Gantenbein, p. 84 . On the 11 th, Co. $M$ men were returning to their camp at Marilao and were caught by Filipinos. Millard and Berry were two men that were caught and when they were found the following morning they both had been fearfully mutilated by the savages and left for dead. Berry died later that morning, but Millard recovered. This is what Bell is referring to when the writes that Filipinos abuse figures and and torture.

36 C. U. Gantenbein, p.10. Troops in the north successfully assaulted and occupied the city of Novaliches. 
April 23, 1899 : Sunday. All quiet in town. 4 Cavite [natives] \& Nebraska got into a mix-up. We lost about 25 men wounded \& killed. Col. Stottemberg of Neb. and his Adjutant were killed. It seems that calvary was ambushed \& Nebs. went to their support were also surrounded and had to charge as bunch to get out. 37

April 24, 1899 : Went into action. House as inspection in place of Nicolly Walker who goes out as boat guard. The work will be an agreeable charge to doing nothing in quarters. Inspectors is a good place to learn \& work in to the office. Took pictures up to photographer in evening. Met Miss Bowman \& Earhart. Went down to train and helped carry wounded who came in from front. Nebraska's still losing men. Agguis [Aguinaldo's] policy seems to be to kill a few of our men each day $\&$ thus wear us out.

April 25, 1899 : About 40 wounded \& dead brought in last night mostly Nebraskas (sic) \& Cavalry. No one yet from Summers Troops are now near Calumpit which will probably be taken in a few days at most. ${ }^{38}$ Mail leaves tomorrow.

April 26, 1899 : Summers heard from. He beat Lawton to meeting place by two days. Captured town and cleared country around Brigade. Lost, killed, \& wounded about 10 men. Am slowly getting on to work at Custom House. Like it much better than at quarters. Mail came yesterday but none for me.

37 C. U. Gantenbein, p.18. Calvary at 3:40 in the afternoon engaged the enemy at Santa Maria. Santa Maria is upriver and the movement started considerably South of the barracks. They advanced to a hill approaching Norzagaray. They fought a small body of insurgents and but then encountered a larger force. Some shelling of the city was done until nightfall.

38 C. U. Gantenbein, p. 87. Most of the fighting was for the village of Angat. The place did become occupied. There were Nebraska men wounded at Norzagaray while the engagement occurred at Angat. A number of boys were reported bathing when they were fired upon and did not have much chance for dressing. The fifty insurgents were dislodged rather shortly when General Lawton and his staff arrived while the fight was in progress. 
April 27, 1899 : Calumpit fell yesterday with loss smaller on side although the city was entrenched behind the most formidable trenches yet uncountered. No further news from Lawton \& Summers. We are a wondering as to plans of the movement. From maps \& what is known of plan of campaign cannot see how much can be accomplished lie in way of capturing Aguinaldo's men It appearing that he is not surrounded and can easily retire. Same old routine of duty at Co. H. [I have] Guard every other night. Nothing news is good to home going. Sheridan left yesterday carrying again sick but no troops. Dillon came up from visit at Corrigedor (sic) where Jim W is. Jim no better but in good spirits.

April 28, 1899 : Col. Mas Arguell \& Lieut Col. Jown [and] Adj. Gen. Luna yesterday [went] through McArthur's lines to proper terms of peace asking for cessation of hostilities: ${ }^{39}$ After interview with Otis they were turned over to Press Marshall. This is probably ending of the insurrection. Calumpit fell $\&$ our troops are still advancing along whole line. The crossing of Rio Grande Pampanga is said by Gen. Wheaton to have been one of greatest feats of modem tactics.

April 29, 1899 : Saturday only work 1/2 day at custom house. Philippine Commissioners left for lines at noon. They asked for armistice of 3 weeks so as to call their congress together $\&$ see what could be done. Otis told them he did not recognize their congress [and] did not know they had one. 10 hours after leaving our lines to surrender unconditionally Commissioners logged hard for two weeks Armistice but it was not granted. In afternoon Carr \& I made a call on the nurses Miss Bowman, Miss Earhart,

39 C. U. Gantenbein, p.87. Colonel Summers was to march on Marunco which they passed through. All battalions pushed on toward to San Rafael which was evacuated by the enemy without a fight. General Lawton was ordered to sustain his march because the Filipinos were making overtures for peace at Manila. The brigade was withdrawn from San Rafael back to Marunco. 
Mrs.Biddell, \& the one who knows mamma. We staid (sic) a big portion of the afternoon $\&$ had a pleasant time.

Sunday April 30, 1899 : Read until 3 PM when Claggett, Holbrook, Morrow, Rea, J. Pratt, Freeman \& myself went across tunnel [and the] river Lilnela where we jollied around all afternoon. Shoot taking several pictures of the gang. Was on guard in evening. 3rd Relief.

May 1, 1899 : Finished Red Rock. Usual work at custom house. In evening Rea \& Freeman took a party of we boys consisting of Dillon, Claggett, Morrow, Jarman, J.Pratt \& myself to dinner at french restaurant. We had a fine time came home shortly past seven \& the gang got into Morrows (sic) room where gossip, joshing, singing, \& storytelling made a pleasant evening last night quickly. We frequently gather together $\&$ sing this way. While in bathroom came near getting into squabble with King Housa drunk $\&$ bluffing as usual but his bluff did not go.

May 2, 1899 : Mail came today. Received one letter from home \& one from Mary S. \& Cleona. Most of the boys received a large mail. Am still trying to get Watsons (sic) discharge. He May leave on next steamer. Commissioners from Aggies [Aguinaldo's] army came in again yesterday and rumor has it that terms of surrender are at last completed and insurrection will be off in a few days. Telegram from McKinley came a few days ago say volunteers must not be kept here unless they so wished and to send them home in order of their arrival.

May $3 \& 4,1899$ : Commissioners Otis could not agree so they left $\&$ we are advancing. Nothing of note occurred. Mail leaves in a few days. Secured all my pictures from Chrene \& sent copies home. Am to take dinner with nurses tomorrow evening. 
May 5, 1899 : Usual round of work at custom house. Nothing new from front except all lines are moving forward. 40 In evening went out to supper only man present. There were five girls at our table Had a fine American meal. Later hospital boys came up \& we had some dancing. Got crafts pass \& it worked okay. Most pleasant evening spent since Honolulu.

May 6, 189941 : Custom house closed at 12. In afternoon Brook Morrow \& I went uptown shopping. Got Pajama and handkerchiefs.

May 7, 1899 : Sunday. Lay around quarters reading all day. About 5 Miss Dunn called for me in her cart we went out on Luenetta listened to music of the people and about 6:30 came over to dinner then drove out toward Emilia. Shower came up so we returned home about 7:30. Had a fine drive. Luenetta (sic) is becoming great place for American women. They all come dressed in their best which is of course fine. They have adapted the Spanish custom of going without hats which is far ahead of a unexpected treat. I came home on Capts [Captain's] pass about 10 p.m.

May 8, 189942 : Nothing of importance occurred today. Received one letter from home.

40 C. U. Gantenbein, p. 88-89. Colonel Summers brigade forded the stream near Marunco and was near San Rafael when 500 insurgents on the right of the city opened fire. The city was surrounded and a charge was made and three Oregon men were wounded. The next day, eight miles beyond Baliuag, Maasin was captured. The Fílipinos were driven away and three Minnesota men were wounded.

41 C. U. Gantenbein, p.90. Major Willis on the 6th and 7th took his battalion on expeditions near San Ildefonso, three miles from Maasin and in the direction of San Miguel. Coming across the enemy formation for battle would be done but no engagement was done.

42 Ibid. An advance was made on San Ildefonso and fire was encountered. Major Diggles of the Thirteenth Minnesota was struck in the head and would die several days later. 
May 9, 1899 : Change in guard. Guard mount it's (sic) quarters at 5 each evening [at] Guard House. There we mix up with F. Much harder work for Corporals. In evening Miss D asked me to go out Saturday to Waterworks. Will try but understand have to have pass from Brigadier of division.

May 10, 1899 : Nothing out of usual routine of Custom House work occurred yesterday. 43 Transport with troops \& mail in few days. Finished reading the Christian. It is one of the strongest books I have ever read.

May 11, 1899 : On guard last night with regulars. More like old guard work Guard mount \& all red tape. Mac came on Hancock also 21 st Inf and Battery E light artillery. Received 6 letters home 3 Lila, Bert, \& Lottie. \$5 in Berts for souvenirs.

May 12,189944 : Everything quiet usual round of work.

May 13, 1899 : Saturday. 21 st Infantry start for lines near Waterworks also some regulars start for Lawton's division to relieve Oregon. ${ }^{45}$ In afternoon get Carmetta [and] get Miss Bowman. Go to convent where I bought 2 Spanish \& two Philippine bags also some doilies 7 a nickel of Juna Cloth. Took some pictures of girls at work \& mothers. Then started out through Paco to San Pedro Macati a fine trip through a fine country.

43 Ibid.,p.11. Gunboats engaged the enemy at San Luis.

44 C. U. Gantenbein, p.90. San Ildefonso was captured. Companies G, K, and F of Oregon were sent up to the city at night to hold it in case there was a attempt was made to recapture it.

45 C. U. Gantenbein, p.91. The city of San Miguel was captured by Co. A of Oregon and one company of Minnesota under Captain Heath. 300 to 600 soldiers were in the first line of entrenchments. The enemy abandoned them and retreated into the city. A few well directed volleys were shot into the city and close to 1,000 Filipinos were taken. 
Every inch in rice fields well cultivated. Country is rolling in nature and hills \& through a jungle of bamboo etc. Took several pictures along the road and several at San Pedro Macati from Gen. Kings old headquarters. Returning reached home at supper time. Took supper at Chinese restaurant with Tuft \& Freeman.

May 14, 1899 : Lay around quarters all AM. At two met Miss Dunne who took me for a drive. Out out toward the waterworks as far as Deposit where we were stopped. Came back \& went out toward old Kansas line pass the Department hospital. Stopped at Cemetery and got flowers. Rode home [in carriage] through Tondo arriving at 4:30. Chicken dinner then guard.

May $15,189946: 23 \mathrm{~F}$ Company to be relieved tomorrow. They go to one of Lower island where there is danger of insurrection. H. Company of 23 relieve them. They are under cannon of a Lieut. McK [McKinnon] to convent where we ordered about a dozen flags. Took some more pictures. Took 3 men and guarded some 3 prizes captured some time since Mosquitoes thick as H- - - .

May 16, 1899 : Everything as usual.

May 17, 189947 : Most inspectors sick today makes work very hard. Had had some fine music by native orchestra in evening. Brook came up from Corrigedor (sic). Jim is no better in fact is worse is getting very weak.

46 C. U. Gantenbein, p.91. Salacat, a small village on the fork of the Rio Grande was captured without opposition.

${ }^{47}$ Ibid. San Isidro was taken after a daring save of the Tarbon bridge. That bridge crosses the Rio Grande and the enemy set fire to the bridge and scouts under Lieutenant Thornton were able to check the flames under possible fire from insurgents. They saved the bridge. San Isidro was captured and rescued a prison of sixteen American soldiers and realized how their comrades had been receiving such severe treatment. 
May 18, 1899 : Much work at Custom House. At 4 got white trousers Tit Jason well. In evening the gang went over to Luenetta (sic) where there was supposed to be some music. Lots of swell American \& Spanish ladies out. Saw [the ship] Wainn come in. Mail Manana.

May 19, 1899 : More mail today. Got one. Still have to do guard duty. I spent a pleasant evening at Gov. nurses with Carr [and] Freeman. \& Taft failed to show up commissioners from Aggies [Aguinaldo's] congress are to come but today with power to make a surrender upon terms laid down in proclamation of Philippine commanders.

May 20, 189948 : Took in market in afternoon got some hats etc. In evening was on guard so could not go to see ladies as promised. Carr did not go either.

May 21, 1899 : Went to Cavite. Place is much changed old quarters are dangerous and about torn down. The town is clean. Spent afternoon and took dinner with Doc Littlefield.

May 22, 1899 : First good rain of season a typhoon is looked to strike lower end of island today sometime. We will have rain and hard winds from now on. Last night telegram went out for to our boys "Send Oregon Reg to Manila at once they are the first to return to us." California goes some weeks later. We will almost surely go in a few weeks. 49

48 C. U. Gantenbein, p.93. The First and Second Battalion Companies A, I, and L under Lieutenant Colonel Yoran engaged the insurgents in a fight. The companies had crossed the Candaba swamp got into an engagement at San Antonio. The Filipinos left and march was resumed to Calumpit.

49 Ibid. The men had been under the impression that a long fatiguing campaign was being planned and their notice of leaving assumed a boisterous character. 
May 23, 1899 : Big storm on Bay too rough for boats or canoes to go or come. Newport in but cannot land mail. Californias on Warren are not able to leave. Oregon boys occurred in around at Calimport [Calumpit].

May 24, 1899 : Typhoon been raging for several days. For now calmer today. About 700 niggers attacked McArthur in the forenoon when the artillery Montana's and Dakotas [Dakotas'] get through with show was but little left. There were are 100 niggers killed and wounded. Regiment expected in Manila. 50

May 25, 1899 : Was not at custom house today. Bothered with diarrhea. Seven regiments came in and a more sunbumed blacker dustier looking lot of boys one could not imagine. ${ }^{51}$ I would given almost anything to have been with them. They are all tired and not in best health but would not have given up the expedition for money. We expect to be off for home in a few weeks.

May 26, 1899 : Remainder of regiment came in this evening. Everyone believes we will start for home in a few days. Acting sergeant of game last night.

May 27, 1899 : Spent afternoon uptown \& in evening crossed to Lunetta and with pass went to see nurses.

50 C. U. Gantenbein, p.12. Insurgents had engaged in harassing outposts at San Fernando and were driven off with a heavy loss. No mention given in records of number lost as Bell states.

51 The regiments are the ones that came from battle in the Northern expedition. 
May 28, 1899 : Sunday. Lay around all morning and about two o'clock again went out to see nurses spent nearly all aftemoon. Succeeded in getting photos of men. Bed drill also photographs of she \& Miss Bowman.

May 29, 1899 : Mail arrived. None for me. Miss Bowman sent down asking boys to call manana evening.

May 30, 1899 : Last evening went with Lieut.Mc [McKinnon], Morrow, Brook, Pratt, Johnston, Freeman, Craft, Walker, Major Eastwick and Cadwell Lt. Murphy and Farrell to the nurses spent a pleasant evening until 11. We leave Custom House tomorrow at least another comes in, 6th artillery, we may have to stay for a few days.

June 17, 1899 : Have not kept diary because most of time have been in field and could not carry it with me. 52 We left Custom House on 2 nd after working a couple days with new men. Our reception at quarter by members of the companies was not the most cordial.

June 18, 1899 : The Reg was put in Hills - Lawton's division for a trip through Mariquina battery and around lake [Laguna de Bai] tomorrow [June 2] we started in. In evening of 3 marched eight miles to Waterworks there we deployed into rice fields got supper and Dept. H Cos first experience as a company in the field. The eight mile hike we stood fairly well but you may be sure we all were ready for supper \& bed.

On the 4th we were up at 3:30 breakfasted and started in the March at 4:30. There were several regiments ahead of us but later in day we took lead. Crossed Maraquina river

52 C. U. Gantenbein, p. 94. What follows is the only actual time that Bell would go on a expedition. Over half of the regiment was said to be unfit for duty because of suffering due to stomach and bowel trouble bad water, food, heat, and sore feet and ringworms. Companies A, B, C, D, E, G, H, I, K, $\mathrm{L}$, and $\mathrm{M}$ under Colonel Summers to approach the city of TayTay on Palawan. Volunteers traveled South from Manila, to Mindoro, then to Palawan. 
and started across valley when about half way across we started up valley it was here we took lead. Our scouts \& a calvary scout was thrown and fired a few shots. After about an hours march and an unaccountable halt for about some time we eventually found right and started back across the width of the valley. Another halt of two hours where a 11 foot slough washed and in eve. went within a mile of a few shots from the scouts.

Warned us the gugus [insurgents] were in front. Saw the order camp. Column right in front into line of squads and old $\mathrm{H}$ was deploying for our first scrap as a company and there was not a man in company but meant to go to the top of the hills if it were in him. In a few minutes came the order forward guide center $H$ company was center so on us depended the line for advance and we all excitement $\&$ desire to make a name for the company went at it with a rush.

The first quarter of a mile was easy through rice patties that were dry and the edges low. Then we came to a swamp and as we were right in the middle of it the gugus opened fire [but] their aim was poor. Just beyond the swamp was [a] cornfield surrounded by chipped juice through which we had to go. Through it, over it, under it any way we could [,] by this time we were all tired and double timing through soft plowed ground was awful. At the quarter edge was a natural rise [,] here we doubled and commenced firing first at will, then by volley's.

We could see but few gugus though they could see us and as we came through the field the range was good and bullets whistled all around us after firing a while we again went forward on the double time another swamp and another cornfield and boys began to drop out. [I] was sick at stomach \& puked but would rather have been shot than quit. Major Heath told me to take the wood but I refused to have the squad.

Now we struck the hills proper and forward we went double time for awhile then a up to fire a few volleys. Several times I threw up but managed to keep going until the top of the hill was reached. Left far in advance of the line, only a few men followed out. The gugus had left so we halted to rest. 
In summarizing up we found we had one man wounded Rea is through the usual no service after this fight we were ordered to wait for the reserve $\&$ when it arrived we went back down the first hill \& resumed the march. There was some 4 or 5 who could not stay with us but caught up when we camped for the night.

Next moming we started up when we camped for the night. Next morning we started up the cut one reg was rear guard [and] progress was slow [we had] no breakfast we passed through Antipolo and reached a small town called Theresa [Teresa] in morning. [We] waited for supply train to catch us \& had bkfst [breakfast] about eight o'clock started on the lake and reached Morong in afternoon after an awful march during which many of the boys were [exhausted] from heat.

Next day we boarded caecues [cascoes] \& came to Manila reaching there about 10 P.M. Our stay at Manila a just few days on boat were without note. We reached Nagasaki on 19 and stayed there several days getting shore leave each day from 7:30 to 6:30. Spent all my time \& money sightseeing. Left Nagasaki evening at 2:30. On morning of 24 entered the Inland sea. So was a fine trip though nothing particular to note.

June 24, 1899 : Inspection today. Sea smooth. Grub good. [Last entry in the diary.] 


\title{
CHAPTER VIII
}

\author{
EPILOGUE
}

\section{ACTIONS CONCERNING THE PHILIPPINES AFTER THE DEPARTURE OF U. S. VOLUNTEER FORCES UNTIL THE END OF THE PHILIPPINE WAR}

On August 7, 1899 Oregon's Second Volunteer Infantry was mustered out in San Francisco, California. ${ }^{1}$ Up to half of General Elwell S. Otis's force of 30,000 soldiers were state volunteers and were slated to be repatriated and discharged during the summer. The volunteers had been recruited to fight the war with Spain and that had officially ended on April 11, 1899, with the formal exchange of ratified treaties. These volunteers then had to be discharged within six months. General Otis was able to persuade only ten percent of the state volunteers of all states to reenlist in the newly formed national units. He offered a five hundred dollar bonus for those willing to do so. ${ }^{2}$ The volunteers had been confident that the war would be over in a matter of months. The rainy season in the Philippines had begun in June and few desired to remain longer. If one was a veteran of six months combat, as most volunteers were, it is hard to conceive why one would want to remain in the field for two more years. That ten percent actually did reenlist is still a wonder. One possible explanation is that the soldiers had nothing to look forward too back at home.

\footnotetext{
1C. U. Gantenbein, p.14.
}

${ }^{2}$ Stuart Creighton Miller, Benevolent Assimilation : The American Conquest Of The Philippines, 1899 - 1903, (New Haven: Yale University Press, 1982), p.189. Hereafter cited as S. C. Miller. 
Much of the desire to leave was produced by the disillusionment that is brought about when the expected glamour of combat did not materialize and the dreary restrictions of army life, climate, sickness, and boredom of remote barrios became a reality. ${ }^{3}$ Bell's diary describes his own disenchantment, and similar feelings were most assuredly felt by a good many more.

The U.S. Army took the leading role in bringing the conclusion of the Philippine insurrection over the next three years until Theodore Roosevelt declared the war over in July, 1902. The army hoped to bring a quick end to the war and also follow a benevolent course of action with the Filipinos. The goal was to show the benevolent character of the American government, making it easier for the United States to establish a firmer control of the islands, and improve the well-being of the Filipinos themselves. ${ }^{4}$ One of the first problems the Americans faced was maintaining law and order. The problem with this was the fact that one had to work within the existing framework of the Spanish laws that Filipinos were familiar with. The military government were able to reestablish courts and give them both civil and criminal jurisdiction. ${ }^{5}$ Moving outside Manila the army began to clean the sanitary conditions of the towns and villages. If crops or supplies had been destroyed by wars fighting or confiscated by the revolutionaries, Americans distributed food to villages, hospitals, lepers, and prisoners of war. This was a powerful benevolent image showing Americans wanting to help and not harm the Filipinos. ${ }^{6}$

3 S. C. Miller, p. 190.

4 John Morgan Gates, Schoolbooks And Krags : The United States Army In The Philippines, 1898 - 1902, (Westport, Connecticut : Greenwood Press, 1973), p.84-85. Hereafter cited as J. M. Gates.

5 J. M. Gates, p.86.

6 J. M. Gates, p. 87. 
It was the development of the schools that was appreciated by most Filipinos. General Otis wanted to open as many schools as possible because of the help education would bring to the pacification campaign. This was also a general principle of pacification. Very often a school was the first thing established in a town, even before developing a municipal government. ${ }^{7}$ The schools generated much goodwill between the military and Filipino people. Developing municipal governments was undertaken next. General Order No. 43, issued August 8, 1899, stated that the governments were developed to "Promote peace and tranquility...to impress proper respect for property, ...to reopen churches and schools; in fine to render life property and individual liberty secure." 8 Municipal governments were formed with the same dedication as schools had been.

Americans generally were optimistic about the war and had reason to be. Many Filipinos were reluctant to fight the U.S. Army rule. The revolutionaries were criticized by the Filipinos because of the abuses of robbery, rape, and murder that occurred. ${ }^{9}$ The revolutionaries were divided among themselves by ethnic lines, and this was one of their main problems. Aguinaldo and most of his men were Tagalogs and concentrated themselves in central Luzon. In the south the people were Visayan and did not want Tagalog rule. The situation caused intense worry for the revolutionary government of the Tagalog. 10 Filipinos in the few towns that Americans controlled did cooperate with the Americans and served as spies and scouts against the revolutionaries.

7 James H. Blount, The American Occupation Of The Philippines : 1898-1912, (New York : Knickerbocker Press, 1913) p.563.

${ }^{8}$ Congressional Records, 56th Congress, 1st session, vol. V, P.144-145.

${ }^{9}$ Brian McAllister Linn, The U.S. Army and Counterinsurgency in the Philippine War, 18991902 (Chapel Hill : University of North Carolina, 1989), p.74-75. Hereafter cited as B. A. Linn. 
The Filipinos striving for independence made effective use of propaganda to woo support for their cause. Aguinaldo attempted to appeal to American opposition to annexing the Philippines by stating that he was not making war on the United States but upon the imperialists who did not want to let the Filipinos govern themselves. 11 With the withdrawal of the Volunteers, the American army could only hold certain cities and key points on islands and could not prevent the revolutionaries from exerting pressure on the population. Some Filipino citizens feared that Americans would eventually leave, and leave the Philippine government in the hands of Tagalogs. Many of the reforms that Americans began in municipalities contradicted local customs. American rule did represent a threat to Filipino culture. Health regulations forced the Filipinos to be cleaner than they wanted to be, and Americans outlawed Filipino pastimes such as gambling and cockfighting. In the governments that were created the rulers were the educated minority and had a lack of public responsibility, and graft and corruption became prevalent. ${ }^{12}$

In October 1899, General Otis planned an offensive to eliminate the revolutionaries working against the help the United States was giving the towns. It ended in a success of what Gen. Arthur McArthur called "general enervation."13 The Filipino revolutionary army as a fighting force did cease to exist. Americans were convinced they had won.

General Otis relinquished command over the army, now totaling 60,000 , in the Philippines to General McArthur on May 5, 1900. McArthur wanted to continue the policy of benevolent pacification and continued to use the schools as an integral part of his pacification campaign. What occurred changed his view of the war. The Filipinos were now convinced of the futility of their resistance of fighting Americans with a regular force.

11 J. M. Gates, p. 102.

12 J. M. Gates, p. 104.

${ }^{13}$ Congressional Record, 56th Congress, Ist Session, vol. III, p.467. 
Following the successful campaign of General Otis, Aguinaldo and his staff decided to fight in the fashion of guerrilla warfare. The objective was to tire the Americans and make their occupation of the Philippines as costly as possible. Guerrillas were to constantly harass the Americans by raiding supply trains, small patrols, and detachments. ${ }^{14}$ They became a hidden enemy. Ambushing, sniping, and sabotage were typical tactics.

The revolutionaries used propaganda effectively by citing American crimes of rape, looting, murder of prisoners, and using exploding bullets. 15 When propaganda failed to stop Filipinos from cooperating with Americans, the guerillas used terrorism. Judgements and executions by revolutionaries took place on the spot. Rewards were paid to those who assassinated officials that collaborated with Americans. Penalties invoked on Filipinos by revolutionaries ranged from fines, beatings, buming of homes, decapitation, and burial alive. ${ }^{16}$ The Americans found it impossible to garrison all towns. The U. S. army could go into a town and establish a school, a municipal government, start public health programs and move on to another town. This would leave those that collaborated with them to the mercy of revolutionaries.

The U. S. Army divided the Philippine main island Luzon into four small provinces. This had to be done because of the small number of U.S. forces, ambivalent policies, rugged terrain, and poor communications. The officers in charge of each province soon found that the policy of benevolence had to be altered or abandoned altogether. Each province began to develop its own counter-insurgency methods and the campaigns in all

14 S. C. Miller, p. 93-98.

15 J. M. Gates, p. 160.

16 J. M. Gates, p. 165. 
four were fought independently of each other. In each of the four, guerrilla warfare was different and therefore local policies and methods were different. ${ }^{17}$

The First District was the Department of Northern Luzon. It was originally seen as a place hostile to a Tagalog - dominated Philippine Republic. When it was discovered that guerrillas actually controlled civil governments, Americans fought short but intensive campaigns that cleared provinces from guerrilla influence. Martial law was declared, civic officials were held accountable for townspeople actions, and travel was restricted. In the fall of 1900, revolutionaries launched a brief offensive, the American response was immediate and drastic and many crops were destroyed. By the late spring of 1901 , the first - district was completely pacified. ${ }^{18}$

The Second District was the Department of Southern Luzon. A powerful and united resistance was established there. The guerrillas had more popular support and were well led. There was no unified strategy in army leadership throughout 1900. In 1901 the guerrilla forces were forced to surrender key officers and were driven into a few isolated areas. In late 1901, American Brig. Gen. J. Franklin Bell did a thorough and complete district pacification. The guerrillas were separated from the population. Large expeditions were sent into guerrilla strongholds, food supplies were destroyed, and the native elite had to commit themselves to the army in order to survive. The counterinsurgency policies worked and all resistance collapsed within a few months. 19

The Third District was in another part of Southem Luzon. The guerrillas went into the hills with much of the population. They spent most of the time controlling the countryside and refúsing to engage with the army. The army enticed the civil population

17 B. A. Linn, p. 163.

${ }^{18}$ B. A. Linn, p. 31-60. The complete army pacification program in the First District is told.

19 B. A. Linn, p. 120-161. The complete army pacification program in the Second District is told. 
back into the towns with benevolent policies of civil government and schools. Then they concentrated on making the hills inhospitable for the guerrillas. They cut the food supply and carried out harassing attacks with small patrols. This caused the revolutionaries to launch attacks on towns occupied by U. S. troops. By mid - 1901 most guerrilla bands had surrendered. 20

The Fourth District was also part of Northern Luzon. The guerrillas here were weak and poorly led. Most guerrilla resistance had collapsed in 1900 and most of the insurgent war was fought in the hills and away from the towns. Brig. Gen. Frederick Funston combined the anti - Tagalog feeling of the local Filipinos, a fine intelligence network, and a few active military operations to weaken significantly guerrilla resistance. ${ }^{21}$

One action by Funston that was of considerable merit was his disguise as prisoner, deceiving the revolutionaries, and capturing Aguinaldo in his own Northern Luzon camp on March 23, 1901. Near the end of April, Aguinaldo issued a proclamation asking those still in arms to surrender. Numerous revolutionaries did surrender in the two months following the event because they agreed with Aguinaldo that peaceful existence under the Americans was better than continuing guerrilla warfare. ${ }^{22}$

The final campaigns of this conflict took place at the end of 1901 and into the middle of 1902. On the island of Samar in the town of Balangiga, C company of the 9 th Infantry was almost totally massacred and revolutionaries started attacking towns and U. S. Army troops. Brigadier Gen. Jacob H. Smith conducted the campaign to stop the insurgents. On Samar he used widespread destruction of property in an attempt to force the inhabitants to cease supporting the guerrillas and turn to the Americans from fear and

20 B. A. Linn, p. $96-118$

21 B. A. Linn, p. $64-94$

22 David Howard Bein, Sitting In Darkness : Americans In The Philippines, (New York : Viking, 1986), p.230. 


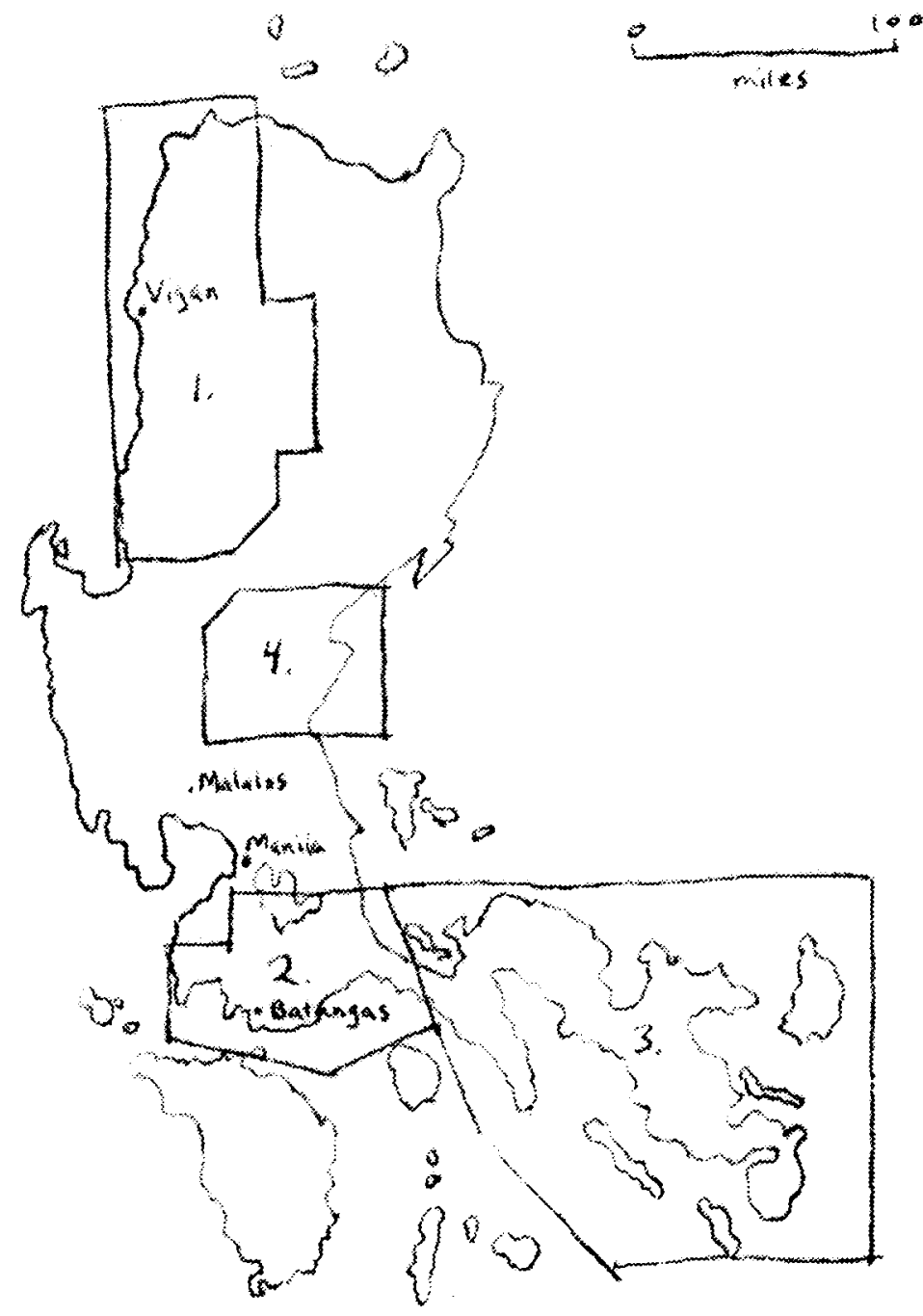

Bigure 7. The Four Districts of Luzon. 
starvation. ${ }^{23}$ One Army Major reported that in an eleven day period, his troops burned 255 dwellings, slaughtered 13 carabao, and killed 39 people $^{24}$. This obviously accomplished little toward pacification in the manner of having the Filipinos of the area support Americans and their policies. But on February 18, 1902, the revolutionary leader Vicente Lukban was captured and his successor surrendered at the end of April. His surrender was partly due to the pacification policy that Americans started of giving much favorable treatment to the Filipinos that took no active or voluntary part in the revolt.

After three years of continuous warfare the American army defeated the Philippine revolutionaries. By May, 1902 the last strongholds of rebellion were pacified. The civil and military forces began to think in terms of amnesty and reconstruction. Theodore Roosevelt officially published a peace proclamation effective in the islands on July 4, 1902. A full pardon was given to all Filipinos who participated in the revolt unless one had been convicted of murder, rape, arson, or robbery. The civil authority was given supremacy over the military affairs of the island. ${ }^{25}$

Three factors were involved in ending the Philippine opposition to United States control. The first involved efforts of winning Filipino support and giving the Filipinos those things they could not get under Spanish rule. The Filipinos gradually realized that little could be gained from supporting the revolution and resisting the Americans. A second factor involved separating the populations and the guerrillas. Once Filipinos saw the advantages of American rule, the natives became a powerful weapon against the insurgents.

23 S. C. Miller, p. 202-204.

${ }^{24}$ Congressional Record, 57th Congress, 2nd Session, vol.XII, p. 441.

25 J. M. Gates, p. 281. 
The third factor that allowed Americans to gain control was using American military force to defeat revolutionary insurgents in the fields. ${ }^{26}$

The Americans won the Philippines. Most of the problems that occurred in the Philippines after the war were a result of colonial rule and not necessarily a result of the pacification program. Many tactical military lessons were leamed from fighting in the Philippines. The lessons of fighting an insurgency that wanted to give the right of self determination to its people appeared to have been lost almost sixty years later in the next Southeast Asian war involving the United States.

Oregon Volunteers were actively involved in part of the four year conflict that - spanned the war against Spain and the struggle against the Filipino insurrectionists. What Bell wrote in his diary probably typified the feelings of many soldiers in the $1898-1902$ war and insurrection. The war was fought in an idealistic, simple-hearted, and patriotic aura that was greatly enhanced by the immensely popular victory over Spain. Bell represented a youth enthralled by imperialism at the turn of the century. Naively optimistic young Americans, like Bell, wanted to go to a frontier overseas just like the western frontier that challenged Bell's parents and grandparents. His diary represents the way a young man's mind grows and changes once faced with the reality of military life and death and the actual combat.

Based on the diary and the perceptions expressed by Bell on soldier life, warfare, and being away from home, one can draw some evaluations of how the war experience affected the enlisted men that fought in the Oregon Volunteers. Bell never expressed a desire to kill an enemy and show the superiority of America. Rather, Bell felt he had do his duty and perform it well and come back home. What would occur in the meantime would change his perceptions of what duty involved. He never felt any better or worse because 
he was not regular army, which was typical if one considers what occurred in Congress to show the importance of state militias.

From the beginning there was criticism expressed about the conditions that must be undertaken in order to have performed his duty. He had a lot of problems with the food on the ship. This was normal considering so many men were traveling on such a small ship and so much food had to be kept to feed so many. It was obvious that refrigeration was crude in order to store so much for so many. He wrote of tainted meat, eating very small meals because of what can be kept under refrigeration had to be shared equally by all the enlisted men. Bacon, potato, hard tack, and coffee were expressed as not being adequate for a soldier of the size he was. The living conditions on the ship were horrid and he wondered what he got into when there is no fresh water for washing dishes and bathing and all became filthy and dirty. The sleeping conditions were cramped and when so many get seasick or dysentery the smell made beds a most terrible place to sleep. He learned some underhanded dealing in his actions of working with the cook and with his friend when they rotated job positions in order to get more food.

He learned about humanity and the strength of one's character. This showed his naive optimism about his journey. He founds out that every one is for himself and one had to get as much out of the other fellow as one could. He tried to show that he was of moral character by commenting on how hard the priest's job is on ship. He saw and heard foul language and joking around done by the boys and did not understands why it is allowed to continue. Bell spoke of Christian Science twice in his diary but no mention is made of prayer and his actions attempted to show a moral character but there is a sense he portrayed himself like that so as to remain honorable to his girl at home. One statement is made, again showing his naive optimism, when he wrote that a woman's presence made a man act differently. It was a wonder that he would be surprised and not have already known it. Groups of men together like that on a ship not appreciating conditions, food, and their sickness, were not going to speak positively to each other about life's meaning or what is 
happening to them. They were going to talk a lot of exaggerations and how they felt and disregard proper manner. They developed a negative attitude early in their service because of the conditions they had to endure to get to their job they volunteered for.in the Philippines.

The enlisted men, once there, had a lucky strike occur. They do not have to wait long to see any action. The fall of Guam on their way there shows them action may be seen soon. Once the Spanish surrender, they had a purpose in their job of disarming them. In the following five months the affect of the war could be seen in what Bell wrote. There were so many rumors and talk of going home, they felt they had done their job and nothing should have kept them there. No explanations are given by officers why they were not leaving and this made them realize how the army worked and how pointless their presence was. They do not feel anything for the Filipinos; they were there to fight the Spanish and they wanted to return home. The letters from home, from girls, and the packages, made the men realize the actual distance they were from loved ones. They resorted to games of chess and billiards to relieve their stress. There was a sense of unhappiness with the army, but they all felt it and actions drew their companies closer.

Once the fighting started, Bell and his men were on duty at the Custom House and remained on duty there for several months. They were still affected by the war even though they were not seeing any action. There was a sense of the Filipinos being in the wrong and this negative attitude later comes out in calling them "gugus" which was no different than the calling of the enemy of another Southeast Asian war 60 years later, “gooks."

Another way the war experience affected the enlisted men was when friends died in actual combat, and disease. Several thousand Americans contracted tropical diseases such as typhoid and malaria and little could be done to control it or stop it. Actual combat for Bell and his company brought out the most lasting experiences of their work. He spoke of getting sick as people around him died. He wanted to be a hero. He wrote at one point that 
the campaign depended on $\mathrm{H}$ company for advancement along the front line and how there was excitement and desire to make a name for the company. In the end of his Morong expedition, he sensed the futility of the operation for they just held their place for a few days and retreated back to Manila and then shipped home. Certainly, it is very possible for one to become cynical when one wondered what was accomplished by one's actions.

The war experience almost certainly continued to affect them once they reached home. Such problems as feelings of dishonesty about what the United States had hoped to accomplish when boys were sent over, and then how little was solved in dealing with the Filipinos could cause one to ask questions when men are called to go into action again. Problems could occur back home with betrayal of wives or girls that did not want to wait any longer for their men to retum. Some men had to deal with what they did while being away from their spouse, especially if they were dishonorably discharged because of their actions such as raping a Filipino.

And finally the war experience brought them home to a different world that was undergoing change. Rapid development in city life and national life in transportation, industry, the growth of labor unions and newer markets to get resources from and give products to were only a few of the new conditions the returning veterans faced. One such market would be the Philippines. And seventeen years later, the United States and some of the same soldiers from the Philippine conflict would be involved in a different war, in another part of the world for one of the reasons the Philippines were fought, the American desire of wanting to overthrow an evil power and help replace unfair rule with a just and democratic one.

Americans grow up in different world now and in some ways the Americans never completely ended its Philippine rule. Americans are to leave their last created Philippine outpost in 1993, a site they have held in the Philippines since Dewey first occupied Subic Bay in 1898. This Spanish - American war and Philippine insurrection that began with the state volunteers who fought there along with all the rest of the soldiers and sailors can thus 
finally be declared over and one can close a fascinating military chapter on American history.

After his Philippine Oregon Volunteer militia service, Chriss A. Bell's whereabouts remained a mystery. It can be properly assumed that he came back to the United States and most likely retumed to Oregon to raise a family. In March, 1989 a relative of his, perhaps a granddaughter, by the name of Edna - Ellen Bell gave his diary as a gift to the Oregon Historical Society Library Manuscripts department. All attempts by this author to contact a Edna - Ellen Bell in the Portland Metropolitan area have been futile.

Charles Jarman and Don P. Rea also kept diaries of their service in the Philippines from May 2 to July 1, 1898. Those diaries were given as a gift to the Oregon Historical Society Library Manuscripts Department by Ms. Robert Leedy in September, 1986. How this lady came across those diaries, and how she is related to Jarman and Rea remains a mystery and if that mystery is ever solved, what happened to Jarman and Rea after their Philippine service may then be found out. When one gives a document to their Manuscripts Department,.the Oregon Historical Society unfortunately keeps no record of how people are related to the documents they receive, or their whereabouts. 


\section{REFERENCES CITED}

Alger, Russell A. The Spanish American War. New York : Harper, 1901.

Bacllagon, Uldarico S. Philippine Campaigns. Manila : Graphic House, 1952.

Bein, David Howard. Sitting in Darkness : America in the Philippines. New York : Viking, 1986.

Benjamin, Jules R. The United States and Cuba: Hegemony and Dependent

Development 1880 - 1934. Pittsburgh : University Of Pittsburgh Press, 1977.

Blount, James H. The American Occupation of the Philippines : 1898 - 1912. New

York : G. P. Putnam, 1925.

Congressional Record. 54th Congress. 1st Session. Vol. XXVIII.

55th Congress. 2nd Session. Vol.XXXI.

56th Congress. 1st Session. Vol.III.

56th Congress. 1st Session. Vol.V.

57th Congress. 2nd Session. Vol.XII

Chadwick, French E. The Relations of the United States and Spain. 2 vol. New York :

Charles Scribners Sons, 1909.

Chapman, Charles E. A History of the Cuban Republic : A Study in American Politics.

New York : Macmillan, 1927.

Coletta, Paolo, ed. Threshold to American Internationalism : Essays on the Foreign

Policies of President William McKinley. New York : Exposition Press, 1970.

Constantino, Renayo. A History of the Philippines. New York : Monthly Review Press, 1975. 
Cosmas, Graham A. An Army for Empire : The United States Army and the Spanish American War. Columbia, MO : University Of Missouri Press, 1971.

Dodson, W. D. B. Official History of the Operations of the 2nd Oregon Infantry United States Volunteers in the Campaign in the Philippines. San Francisco : Hicks Judd, 1899.

Fernandez, Leandro H. The Philippine Republic. New York : Columbia University, 1926.

Foner, Philip S. The Spanish - Cuban - American War and the Birth of American Imperialism : 1895 - 1902. New York : Monthly Review Press, 1972. Forbes, Cameron W. The Philippine Islands. Cambridge, MA : Riverside Press, 1928. Gantenbein, Calvin U. The Official Records of the Oregon Volunteers in the Spanish War and Philippine Insurrection. Salem, OR : W. H. Leeds, 1902. Gates, John Morgan. Schoolbooks and Krags: The United States Army in the Philippines : 1899 - 1902. Westport, CO : Greenwood Press, 1975. Grunder, Gavel A.and Livezey E. Williams. The Philippines and the United States. Norman, OK : University Of Oklahoma, 1951.

Kalaw, Maximo M. The Case for the Filipinos. New York : Century Company, 1916. Leroy, James A. The Americans in the Philippines. 2 vol. Boston : Houghton Mifflin, 1915.

Linn, Brian McAllister. The United States Army and Counterinsurgency in the Philippine War 1899 - 1902. Chapel Hill : University Of North Carolina, 1989.

May, Emest R. Imperial Democracy: The Emergence of America as a Great Power.

New York : Harcourt, Brace, World, 1961.

Mayo, Katherine. The Isle of Fear : The Truth About the Philippines. New York :

Harcourt, Brace, World, 1925.

Miller, Stuart Creighton. Benevolent Assimilation: The American Conquest of the Philippines 1899 - 1903. New Haven : Yale University, 1983. 
Nance, John. "Oregon in the Philippines." Oregon Humanities. (Summer, 1991).

New York Times. 18, 19, 20, 22, 23, 24, 26 April; 1, 7, 9, 18, 26 May; 5 June 1898.

O' Toole, G. J. A. The Spanish American War An American Epic - 1898. New York :

Columbia University, 1926.

Rickover, Hyman G. How the Battleship Mainewas Destroyed. Washingto D. C. :

Naval Historical Division, 1976.

Schurman, Jacob G. Philippine Affairs : A Retrospect and Outlook. New York : Charles Scribners Sons, 1902.

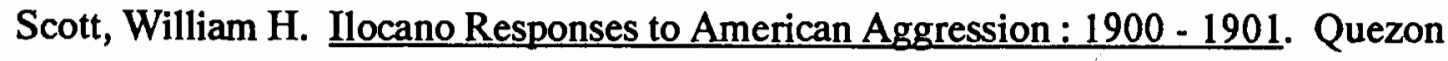

City, PI : New Day, 1986.

Sturtevant, David R. Agrarian Unrest in the Philippines : Guardia de Honor-

Revitalization Within the Revolution and Rizalistas - Contemporary Revitalization

Movements in the Philippines. Center For International Studies : Ohio University, 1969.

Trask, David F. The War With Spain in 1898. New York : Macmillan, 1981.

Zomow, William F. "Frederick Funston Captures Aguinaldo." American Heritage. IX (February, 1958). 


\section{APPENDIX}

\section{MEN OF CO. H FROM FIGURE I.}

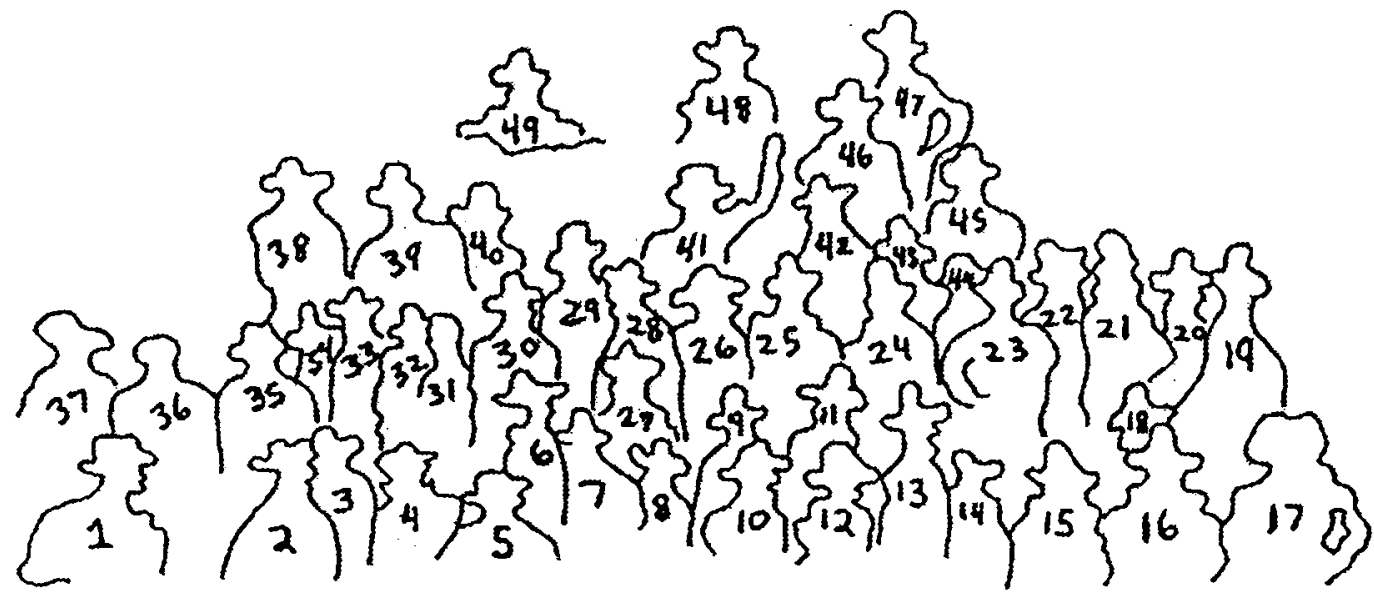

1. Morrow

2. Gritzmacher

3. Crary

4. Luce

5. Chase

6. McDonell

7. Whitelread

8. Clagett

9. Barrett

10. Clagett

11. Walker

12. Herb

13. Scott

14. Doughty

15. Latham

15. Kerron
17. Fremont

18. Harder

19. Taft

20. Civilian

21. M. Pratt

22. Knox

23. C. Stephens

24. A. Stephens

25. Williamson

26. F. Watson

27. Kaltz

28. Weod

29. Noltner

30. Dustin

31. Anderson

32. Coleman
33. Dooley

34. Bodley

35. S. Holbrook

36. Hartman

37. Spencer

38. Ludwig

39. Percy

40. R. Dobie

41. Rodman

42. S. Dobic

43. Baker

44. Wetterborg

45. Richardson

46. Fehrenbacher

47. Rasch

48. Scullv
49. Manning 